CONTRERAS, Lautaro. "Reglas extrajurídicas y creaciones de riesgos toleradas o desaprobadas en los delitos culposos de homicidio y lesiones".

Polít. crim. Vol. 13, № 25 (Julio 2018) Art. 11, pp. 387-444.

[http://www.politicacriminal.cl/Vol_13/n_25/Vol13N25A11.pdf]

\title{
Reglas extrajurídicas y creaciones de riesgos toleradas o desaprobadas en los delitos culposos de homicidio y lesiones
}

\section{Vorrechtliche Regeln und tolerierte bzw. mißbilligte Risikoschaffungen bei fahrlässigen Tötungs- und Körperverletzungsdelikten}

\author{
Lautaro Contreras Chaimovich* \\ Legum magister y doctor por la Albert-Ludwigs-Universität (Alemania) \\ Profesor asociado del Departamento de Ciencias Penales, Universidad de Chile \\ lcontreras@derecho.uchile.cl
}

\section{Resumen}

El presente artículo analiza la función que, en el marco de los delitos culposos de homicidio y lesiones corporales, desempeñan las reglas extrajurídicas para distinguir entre riesgos tolerados o desaprobados por el Derecho. Luego de una toma de posición sobre la estructura de los delitos imprudentes de resultado, se explica por qué las reglamentaciones extrajurídicas no contienen prohibiciones o mandatos vinculantes para los individuos, y se examinan aquellos casos en que el Derecho positivo se remite a ellas. A continuación, se desarrollan los presupuestos bajo los cuales las reglas extrajurídicas permitirían calificar un riesgo para la vida o salud individual como tolerado o desaprobado, y se aclara por qué en una gran mayoría de casos tales presupuestos concurren. Finalmente, se analizan en forma pormenorizada los efectos que generan la observancia y la inobservancia de reglamentaciones extrajurídicas para afirmar o negar el injusto de conducta de los delitos culposos de homicidio y lesiones de los arts. 490 y 491 del Código Penal.

Palabras clave: teoría de la imputación objetiva, delitos culposos, reglas extrajurídicas, normas técnicas, lex artis, artículos 490 y 491 del Código Penal.

\section{Zusammenfassung}

Der vorliegende Aufsatz analysiert, im Rahmen fahrlässiger Tötungs- und Körperverletzungsdelikte, die Rolle der vorrechtlichen Regeln in der Abgrenzung zwischen tolerierten und missbilligten Risiken. Im Anschluss an eine Stellungnahme zur Struktur der fahrlässigen Erfolgsdelikte, wird erklärt warum die vorrechtlichen Regelungen für die Individuen keine bindenden Verbote oder Gebote beinhalten und es werden jene Fälle untersucht, in denen sich das Positive Recht auf diese bezieht. Daraufhin werden die Voraussetzungen erarbeitet, unter denen die vorrechtlichen Regeln ein Lebens- oder Gesundheitsrisiko als toleriert oder missbilligt einstufen könnten. Und es wird erklärt, warum in der großen Mehrheit der Fälle solche Voraussetzungen erfüllt sind. Schließlich werden jene Effekte im Detail analysiert, die die Beachtung oder Missachtung der vorrechtlichen Regeln erzeugen, um das

\footnotetext{
* Este trabajo ha sido desarrollado en el marco del proyecto Fondecyt de Iniciación No 11160021, "La determinación del deber de cuidado en los delitos culposos de resultado".
} 
Polít. crim. Vol. 13, № 25 (Julio 2018) Art. 11, pp. 387-444.

[http://www.politicacriminal.cl/Vol_13/n_25/Vol13N25A11.pdf]

Verhaltensunrecht der fahrlässigen Tötungs- und Körperverletzungsdelikte der Artikel 490 und 491 des chilenischen Strafgesetzbuches zu bejahen oder zu leugnen.

Stichworte: Theorie der objektiven Zurechnung, Fahrlässigkeitsdelikte, vorrechtliche Regeln, technische Normen, lex artis, Artikel 490 und 491 des chilenischen Strafgesetzbuchs.

\section{Introducción}

Tratándose de los delitos culposos de homicidio y lesiones, es frecuente que los tribunales acudan a pautas de cuidado establecidas en reglas extrajurídicas para concretar el injusto de conducta $^{1}$. De este modo, reglas del arte médico-quirúrgico, normas chilenas dictadas por el Instituto Nacional de Normalización en materia alimentaria, manuales de instrucciones para el manejo de maquinarias peligrosas, recomendaciones no estatales para una planificación segura de vuelos hacia zonas remotas, etc., son considerados para valorar el riesgo creado (para la vida o salud individual) como tolerado o desaprobado. La doctrina, en cambio, se muestra escéptica frente al rendimiento de las reglas extrajurídicas para concretar la conducta típica de los delitos culposos de resultado ${ }^{2}$. Así, por ejemplo, Roxin sostiene que no se puede atribuir a este tipo de reglas la misma importancia que tienen los programas estatales de reducción de riesgos, previstos en leyes y reglamentos, argumentando que la fijación de los peligros tolerados - contenida en reglas extrajurídicas - tiene su origen en el seno de instancias

\footnotetext{
${ }^{1}$ Véanse, entre otras, las siguientes sentencias: Corte Suprema 04.04.2014, ROL 185-2014 (considerando $21^{\circ}$ ); Tribunal de Juicio Oral en lo Penal de Concepción 10.12.2013, RIT 251-2012, RUC 1000227267-4 (considerando $10^{\circ}$ ); Corte Suprema 10.07.2013, ROL 9694-2012 (considerando 13 ${ }^{\circ}$ ); Corte Suprema 27.07.2009, ROL 5575-2008 (considerando 9²); Corte Suprema 16.06.2009, ROL 5076-2008 (considerando $27^{\circ}$ ); Corte Suprema 16.04.2009, ROL 1882-2008 (considerando 20); Corte Suprema 04.06.2008, ROL 4342008 (considerando $8^{\circ}$ ); Corte de Apelaciones de Coyahique 05.03.2008, ROL 32-2007 (considerando 25 ${ }^{\circ}$ ); Corte Suprema 23.04.2007, ROL 6585-2006 (considerando $7^{\circ}$ ); Corte Suprema 19.01.2005, ROL 9-2003 (considerando $1^{\circ}$ ).

${ }^{2}$ Entre otros BOREAN, Damián, Las reglas técnicas de la construcción en el Derecho penal alemán - Un aporte al análisis constitucional de tipos abiertos y a la concreción del deber de cuidado en delitos imprudentes, Buenos Aires: Ad-Hoc, 2015, p. 103; CORCOY, Mirentxu, El delito imprudente - Criterios de imputación del resultado, Barcelona: PPU, 1989, p. 110 y s.; FEIJÓO, Bernardo, "La imprudencia en el Código Penal de 1995 (cuestiones de 'lege lata' y de 'lege ferenda')”, CPC n 62 (1997), pp. 303-365, p. 338; FERNÁNDEZ, José, "El delito imprudente: la determinación de la diligencia debida en el seno de las organizaciones", Revista de Derecho (Universidad Austral de Chile), Vol. XIII (2002), pp. 101-121, p. 111; GÓMEZ, Pilar, Tratamientos médicos: su responsabilidad penal y civil, $3^{\mathrm{a}}$ edición, Barcelona: Bosch, 2013, p. 359; JAKOBS, Günther, Strafrecht Allgemeiner Teil, 2a edición, Berlin: Walter de Gruyter, 1991, Sección 7, número marginal 44 (hay versión castellana de la segunda edición de 1991: Derecho penal Parte general (trad. CUELLO, Joaquín; SERRANO, José, Madrid: Marcial Pons, 1997)); JESCHECK, Hans-Heinrich; WEIGEND, Thomas, Lehrbuch des Strafrechts Allgemeiner Teil, 5ª edición, Berlin: Duncker \& Humblot, 1996, p. 582 (hay versión castellana: Tratado de Derecho penal Parte general (trad. OLMEDO, Miguel, Granada: Comares, 2003)); MAYER, Laura; VERA, Jaime, "Caso Pinzas: ¿responsabilidad penal por delito culposo en el ámbito médico? SCS, 23/04/2007, Rol N ${ }^{\circ}$ 6585-06”, en: VARGAS, Tatiana (Directora), Casos destacados Derecho penal - Parte General, Santiago: Legal Publishing Chile, 2015, pp. 149-170, p. 155; ROXIN, Claus, Strafrecht Allgemeiner Teil, Tomo 1, 4ª edición, München: C. H. Beck, 2006, § 24, número marginal 19 (hay versión castellana de la segunda edición de 1994: Derecho penal Parte general (trad. LUZÓN, Diego-Manuel et al, Madrid: Civitas,

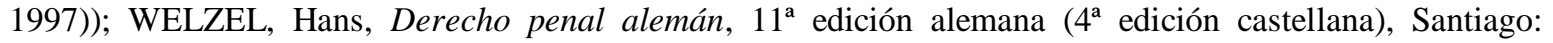
Editorial Jurídica de Chile, 1993, p. 160.
} 
CONTRERAS, Lautaro. "Reglas extrajurídicas y creaciones de riesgos toleradas o desaprobadas en los delitos culposos de homicidio y lesiones".

privadas, carentes de la autoridad e imparcialidad que sí posee el legislador o el Ejecutivo ${ }^{3}$. Por eso, el cumplimiento o la inobservancia de este tipo de reglas es solo un indicio para negar o afirmar la imprudencia de la conducta, siendo indispensable un juicio valorativo complementario del juez. En un sentido similar se expresa Jakobs, quien afirma que lo prohibido por las reglamentaciones extrajurídicas es únicamente un asomo de la naturaleza no tolerada de un riesgo (para la vida o la salud individual), puesto que el consenso al que llegue un cuerpo de expertos ciertamente es "experiencia acendrada", pero, al contrario que la ley, no contiene valoración vinculante alguna ${ }^{4}$.

La doctrina acierta en un punto: al no tener las reglas extrajurídicas fuerza vinculante -puesto que, como se explicará en detalle más adelante ${ }^{5}$, no forman parte del ordenamiento jurídico objetivo-, los riesgos que subsisten pese a la observancia de tales reglas no pueden calificarse como jurídicamente tolerados; en un sentido contrario, la conducta del sujeto que se aparta de las reglamentaciones extrajurídicas no puede valorarse sin más como una creación de riesgos desaprobada por el Derecho ${ }^{6}$.

Reconociendo que las reglas extrajurídicas no constituyen normas del Derecho, el presente trabajo busca responder las siguientes preguntas en el contexto de los delitos culposos de homicidio y lesiones corporales: ¿es posible bajo determinados presupuestos que las reglamentaciones extrajurídicas permitan distinguir entre creaciones de riesgos toleradas y desaprobadas? En caso de que se reúnan tales presupuestos, ¿qué consecuencias tiene que la conducta del sujeto se ajuste o se aparte de la correspondiente reglamentación extrajurídica para negar o afirmar la creación de un riesgo desaprobado? Y finalmente: si no se cumplen

\footnotetext{
${ }^{3}$ En lo que sigue ROXIN, Strafrecht, cit. nota $\mathrm{n}^{\circ} 2$, § 24, número marginal 19. Para Schünemann, lo que la población ha de aceptar como riesgos tolerados no puede ser fijado a través de la decisión de instancias privadas, o especialistas científico-técnicos, sino por intermedio de actos estatales, ya sea del legislador o del juez competente (SCHÜNEMANN, Bernd, "Las reglas de la técnica en Derecho penal", ADPCP (1994), pp. 307341, p. 328). Una opinión distinta es defendida por Nicklisch (cfr. en lo que sigue NICKLISCH, Fritz, "Wechselwirkungen zwischen Technologie und Recht - Zur kontrollierten Rezeption wissenschaftlichtechnischer Standards durch die Rechtsordnung", NJW (1982), pp. 2633-2644, pp. 2638 y ss.). Este autor reconoce una competencia material originaria de los especialistas científico-técnicos en la valoración de un riesgo como tolerado. Estos especialistas no solo tendrían una facultad de definición acerca del componente fáctico de los programas no estatales de reducción de riesgos (vinculado a los cursos causales previsibles que desencadenan ciertas conductas -véase infra 3.1.), sino además podrían valorar la legitimidad de tales programas desde el punto de vista de una adecuada protección de bienes jurídicos. Los elementos fácticos y valorativos de las reglas extrajurídicas estarían vinculados de un modo tan inseparable, que solo podrían ser definidos por aquellas personas que disponen del conocimiento técnico o científico necesario; luego, el juez estaría necesariamente vinculado a la opinión de los especialistas para fijar el cuidado debido. Pero, como correctamente sostiene Schünemann, esta opinión no puede ser compartida, puesto que confunde el plano empírico con el valorativo: una cosa son los riesgos previsibles de acuerdo con la experiencia científica o técnica, y otra distinta es si a los potenciales afectados puede exigírseles la asunción de ese riesgo, cuestión esta última que solo puede ser decidida por el juez teniendo a la vista ciertos criterios materiales (SCHÜNEMANN, Bernd, "Las reglas de la técnica en Derecho penal", ADPCP 1994, pp. 307-341, p. 333 y s.; sobre tales criterios, en detalle infra 3.2. y 3.3.).

${ }^{4}$ JAKOBS, Strafrecht, cit. nota n ${ }^{\circ}$ 2, Sección 7, número marginal 44.

${ }^{5}$ Véase infra 2.3.1.

${ }^{6}$ Cfr. LENCKNER, Theodor, "Technische Normen und Fahrlässigkeit", en: BOCKELMANN, Paul et al (Editores), Festschrift für Karl Engisch zum 70. Geburtstag, Frankfurt am Main: Klostermann, 1969, pp. 490508, p. 494.
} 
Polít. crim. Vol. 13, No 25 (Julio 2018) Art. 11, pp. 387-444.

[http://www.politicacriminal.cl/Vol_13/n_25/Vol13N25A11.pdf]

tales presupuestos, ¿qué efectos tiene entonces en la calificación del riesgo la observancia o inobservancia de la reglamentación extrajurídica por parte del sujeto?

La tesis central que se plantea en este artículo es que, aunque las reglas extrajurídicas normalmente no integren el ordenamiento jurídico objetivo, ellas sí permiten distinguir entre riesgos tolerados y desaprobados, en la medida que pretendan evitar justamente aquella situación de peligro que ha conducido al resultado típico, y sean la manifestación de un vínculo recíprocamente aceptable entre los intereses del destinatario de la regla, por una parte, y los bienes e intereses del sujeto beneficiado con las medidas de control de riesgos previstas en ella, por otra.

Comenzaremos con una toma de posición respecto de la estructura de los delitos culposos de resultado (infra 1) para luego abordar algunas cuestiones generales concernientes a las reglas extrajurídicas (infra 2). A continuación, analizaremos en detalle las condiciones bajo las cuales tales reglas permiten calificar un riesgo para la vida o salud individual como tolerado o desaprobado (infra 3), y explicaremos por qué en una gran mayoría de casos tales condiciones concurren (infra 4). Finalmente, nos detendremos en los efectos que generan la observancia y la inobservancia de una reglamentación extrajurídica para afirmar o negar el injusto de conducta de los delitos culposos de homicidio y lesiones (infra 5 y 6 ).

\section{Toma de posición sobre la estructura del delito culposo de resultado}

\subsection{Las diferencias aparentes entre la tipicidad objetiva de los delitos dolosos y culposos de resultado}

En los delitos dolosos de homicidio o lesiones corporales, el autor se decide por una conducta prohibida por el Derecho, es decir, por un comportamiento que se desvía de lo preceptuado en un deber jurídico típicamente relevante ${ }^{7}$. El autor de tales delitos parte precisamente del supuesto que ha llevado a la prohibición de la conducta; él es consciente de que el curso causal que desencadena su acción generará una situación de incertidumbre para los bienes jurídicos vida o salud individual ${ }^{8}$. Por el contrario, el autor de homicidio culposo o lesiones del mismo carácter no comprende cabalmente la dimensión del injusto típicamente relevante de su conducta; yerra a este respecto ${ }^{9}$. El sujeto no se decide en contra de la vida o salud individual, sino que (simplemente) no presta atención a estos bienes jurídicos, o no toma con suficiente seriedad los peligros que se ciernen sobre ellos, debido a la falta de adopción de medidas de cuidado.

\footnotetext{
${ }^{7}$ Véase FRISCH, Wolfgang, "Gegenwartsprobleme des Vorsatzbegriffs und der Vorsatzfeststellung am Beispiel der AIDS-Diskussion”, en: GEPPERT, Klaus; DEHNICKE, Diether (Editores), Gedächtnisschrift für Karlheinz Meyer, Berlin: Walter de Gruyter, 1990, pp. 533-566, p. 544.

${ }^{8}$ FRISCH, Wolfgang, Vorsatz und Risiko Grundfragen des tatbestandsmäßigen Verhaltens und des Vorsatzes - Zugleich ein Beitrag zur Behandlung außertatbestandlicher Möglichkeitsvorstelllungen, Köln: Carl Heymanns, 1983, pp. 120 y s., 208 y ss.; FRISCH, "Gegenwartsprobleme des Vorsatzbegriffs", cit. nota $n^{\circ} 7$, p. 544.

${ }^{9}$ En este sentido FREUND, Georg, Strafrecht Allgemeiner Teil, 2ª edición, Berlin: Springer, 2009, § 7, números marginales 7, $37 \mathrm{y} \mathrm{s.}$
} 
CONTRERAS, Lautaro. "Reglas extrajurídicas y creaciones de riesgos toleradas o desaprobadas en los delitos culposos de homicidio y lesiones".

Con todo, las diferencias entre los delitos dolosos y culposos de homicidio y lesiones no han de ser sobreestimadas. Desde el punto de vista objetivo en ambas categorías delictivas la lesión al Derecho es -en lo fundamental- la misma ${ }^{10}$. Tanto el autor doloso como culposo infringen una norma de conducta que protege directamente la vida o la salud individual, y que ha de ser siempre legitimada, en tanto restringe la libertad general de actuación u otra libertad especialmente garantizada por la Constitución ${ }^{11}$. La diferencia entre ambos autores descansa únicamente en su actitud interna frente a la lesión de la norma de comportamiento ${ }^{12}$. El quebrantamiento de una norma de conducta representa la creación de un riesgo objetivamente desaprobado, desde una perspectiva ex ante. Tal injusto de comportamiento es un elemento en común de los delitos de resultado (de homicidio y lesiones) dolosos y culposos. La creación de un riesgo desaprobado es precisamente el objeto del dolo en los delitos dolosos ${ }^{13}$; en los culposos al sujeto se le reprocha no haber reconocido o no haber sido capaz de reconocer, en un momento ex ante, la creación de un riesgo desaprobado para el bien jurídico. Por su parte, el contenido del injusto de resultado es también común en los delitos (de homicidio y lesiones) dolosos e imprudentes; en ambos la consumación requiere que el resultado acaecido haya sido la consecuencia específica de la creación del riesgo objetivamente desaprobado.

La descripción que formula la doctrina mayoritaria de la tipicidad de los delitos culposos de resultado pareciera mostrar un panorama distinto al recién expuesto. Así, el injusto de comportamiento en esta clase de delitos no se describe como la creación de un riesgo jurídicamente desaprobado, sino como la lesión a un deber de cuidado unida a la previsibilidad (o reconocibilidad) de la realización típica ${ }^{14}$. Sin embargo, la lesión al cuidado debido no es algo distinto que la infracción de una norma de conducta establecida para la

${ }^{10}$ Así KINDHÄUSER, Urs, Strafgesetzbuch Lehr- und Praxiskommentar, $7^{\mathrm{a}}$ edición, Baden-Baden: Nomos, 2017, § 15, número marginal 41; MURMANN, Uwe, Grundkurs Strafrecht, $3^{\mathrm{a}}$ edición, München: C. H. Beck, 2015, § 30, número marginal 7. No parece ser convincente el planteamiento de Herzberg, para quien la distinción entre delitos dolosos y culposos tiene que hacerse ya en el plano de la tipicidad objetiva; véase HERZBERG, Rolf Dietrich, "Die Sorgfaltswidrigkeit im Aufbau der fahrlässigen und der vorsätzlichen Straftat”, JZ (1987), pp. 536-541, pp. 536 y ss.; rechazando esta postura decididamente FRISCH, Wolfgang, Tatbestandsmäßiges Verhalten und Zurechnung des Erfolgs, Heidelberg: Müller, 1988, p. 40 (nota al pie 155), hay versión castellana: Comportamiento típico e imputación del resultado (trad. CUELLO, Joaquín; SERRANO, José, Madrid: Marcial Pons, 2004).

${ }^{11}$ FREUND, Strafrecht, cit. nota n 9, § 5, número marginal 18; véase también GÖSSEL, Karl Heinz, "§ 42 Struktur und Formen der fahrlässigen Straftat”, en: GÖSSEL, Karl Heinz et al, Strafrecht Allgemeiner Teil Teilband 2 Erscheinungsformen des Verbrechens und Rechtsfolgen der Tat, 8 a edición, Heidelberg: Müller, 2014, número marginal 8: los delitos dolosos y culposos se pueden ver como lesiones de la misma norma de conducta, que obliga a todas las personas a evitar afectaciones a bienes jurídicos. Sobre la infracción de una norma de conducta como condición básica de todo hecho punible véase, entre otros, FREUND, Strafrecht, cit. nota $\mathrm{n}^{\circ}$ 9, § 2, números marginales 5, 8 y 39; KREMER-BAX, Alexandra, Das personale Verhaltensunrecht der Fahrlässigkeitstat - Zur Individualisierung des Bewertungsgegenstands, Frankfurt am Main: Peter Lang, 1999, p. 20.

12 Véase MURMANN, Grundkurs, cit. nota nº 10, § 30, número marginal 7.

${ }^{13}$ Véase FRISCH, Vorsatz und Risiko, cit. nota $\mathrm{n}^{\circ}$ 8, pp. 94 y ss., 118 y ss., 210 y ss.

${ }^{14}$ Así, por ejemplo, FERNÁNDEZ, "El delito imprudente", cit. nota no 2, p. 109; VARGAS, Tatiana, "La imprudencia médica. Algunos problemas de imputación de lo injusto penal", Revista de Derecho Universidad Católica del Norte, Año 17 - N² (2010), pp. 99-132, p. 112 (el deber de cuidado y la previsibilidad “cimientan" la imprudencia); en el Derecho alemán véase, por todos, KÜHL, Kristian, Strafrecht Allgemeiner Teil, $8^{\text {a }}$ edición, München: Vahlen, 2017, § 17, número marginal 18; WESSELS, Johannes et al, Strafrecht Allgemeiner Teil Die Straftat und ihr Aufbau, 46ª edición, Heidelberg: Müller, 2016, número marginal 939. 
Polít. crim. Vol. 13, № 25 (Julio 2018) Art. 11, pp. 387-444.

[http://www.politicacriminal.c1/Vol_13/n_25/Vol13N25A11.pdf]

protección de bienes jurídicos, es decir, que la generación de un riesgo jurídicamente desaprobado $^{15}$. El elemento de la previsibilidad, por su parte, también forma parte del peligro jurídicamente desaprobado; crear un riesgo implica desplegar una conducta que, conforme al conocimiento general empírico, posible o probablemente (o sea, previsiblemente) desencadenará un curso causal coronado por la producción del resultado típico ${ }^{16}$.

\subsection{La dificultad para distinguir entre riesgos jurídicamente desaprobados y riesgos tolerados en los delitos de homicidio y lesiones culposos}

Como la prohibición de desplegar conductas, que de uno u otro modo generen peligros para la vida o salud individual, llevaría a la paralización de actividades cotidianas que traen aparejada una importante utilidad social, es imprescindible distinguir entre riesgos desaprobados jurídicamente y riesgos tolerados por el Derecho ${ }^{17}$. Esa delimitación es especialmente compleja tratándose de los tipos culposos de homicidio y lesiones ${ }^{18}$. Para la doctrina aún mayoritaria, un criterio de solución lo ofrece el modelo de la figura-baremo: hay que preguntarse qué es lo que el ordenamiento jurídico puede exigir a una persona cuidadosa y razonable puesta en la situación concreta y en el rol social del sujeto actuante ${ }^{19}$. Los

${ }^{15} \mathrm{Cfr}$. considerandos $15^{\circ}$ y $21^{\circ}$ de la sentencia de reemplazo dictada por la Corte Suprema el 16.04.2009, ROL 1882-2008. Sobre la equiparación entre infracción de normas de conducta y creación de riesgos desaprobadas véase, entre otros, EISELE, Jörg, "Vorbemerkungen zu den $\S \S 13$ ff.", en: Schönke/Schröder Strafgesetzbuch Kommentar, 29ª edición, München: C. H. Beck, 2014, número marginal 93; GUÉREZ, Pablo, El tratamiento médico curativo y su licitud: el papel del consentimiento del paciente, Cizur Menor: Civitas, 2012, p. 123; MURMANN, Grundkurs, cit. nota $\mathrm{n}^{\circ} 10, \S 30$, número marginal 9; ROXIN, Strafrecht, cit. nota $\mathrm{n}^{\circ} 2$, $\$ 24$, número marginal 10 y s.; VOGEL, Joachim, “\$ 15 Vorsätzliches und fahrlässiges Handeln”, en: LAUFHÜTTE, Heinrich Wilhelm et al (Editores), Strafgesetzbuch Leipziger Kommentar Großkommentar, 12a edición, Berlin: Walter de Gruyter, 2007, números marginales 212 y ss.

${ }^{16}$ Cfr. FRISCH, Wolfgang, La imputación objetiva del resultado - Desarrollo, fundamentos y cuestiones abiertas, Barcelona: Atelier, 2015, p. 60.

${ }^{17}$ Véase MURMANN, Grundkurs, cit. nota $\mathrm{n}^{\circ} 10, \S 23$, número marginal 36; cfr. también FEIJÓO, Bernardo, Resultado lesivo e imprudencia - Estudio sobre los límites de la responsabilidad penal por imprudencia y el criterio del "fin de protección de la norma de cuidado”, Barcelona: Bosch, 2001, pp. 89 y ss. Con la expresión "riesgos tolerados" o "riesgos permitidos" se alude a formas de conducta que, a pesar del peligro que traen consigo en orden a desencadenar determinados cursos lesivos, están permitidas como tales por el ordenamiento jurídico; en consecuencia, no se trata de comportamientos que estén vedados en sí y para los cuales el riesgo permitido formula un permiso que relativiza una prohibición en principio existente, tal como lo haría una causa de justificación (en este sentido FRISCH, Wolfgang, Estudios sobre imputación objetiva, Santiago de Chile: Legal Publishing Chile, 2012, p. 41 y s.). Por eso, no se podría plantear que sobre la persona afectada por el respectivo curso causal exista un deber de tolerancia: una carga semejante solo surge en el contexto de las causas de justificación (cfr. MAIWALD, Manfred, “Zur Leistungsfähigkeit des Begriffs ,erlaubtes Risiko“ für die Strafrechtssystematik", en: VOGLER, Theo (Editor), Festschrift für Hans-Heinrich Jescheck zum 70. Geburtstag, Tomo I, Berlin: Duncker \& Humblot, 1985, pp. 405-425, pp. 423 y ss., de acuerdo con él FRISCH, Wolfgang, Estudios sobre imputación objetiva, Santiago de Chile: Legal Publishing Chile, 2012, p. 41 (nota al pie 18)).

${ }^{18}$ En los homicidios y lesiones dolosos, las acciones llevadas a cabo por el sujeto (uso de armas blancas de hoja larga o armas de fuego, golpes con objetos contundentes en zonas vitales, etc.) representan de forma evidente creaciones de riesgo desaprobadas (cfr. ROXIN, Strafrecht, cit. nota $n^{\circ} 2$, § 24, número marginal 95). En cambio, los riesgos en el ámbito de los delitos culposos son menos elevados y frecuentemente tienen su origen en conductas que traen aparejada una utilidad social (así MURMANN, Grundkurs, cit. nota nº 10, § 23, número marginal 36).

${ }^{19}$ Cfr. por ejemplo FERNÁNDEZ, "El delito imprudente", cit. nota n 2, p. 112; KÜHL, Strafrecht, cit. nota n 14, § 17, número marginal 25; WESSELS, Strafrecht, cit. nota nº 14, número marginal 942. En detalle sobre el modelo de la figura-baremo CORCOY, El delito imprudente, cit. nota nº 2, pp. 134 y ss.; GIL, Alicia, El delito 
CONTRERAS, Lautaro. "Reglas extrajurídicas y creaciones de riesgos toleradas o desaprobadas en los delitos culposos de homicidio y lesiones".

conocimientos y capacidades especiales del autor también tendrían que ser tomados en cuenta en la valoración de la conformidad o no a Derecho de la conducta ${ }^{20}$; consideraciones prácticas, que facilitan la vida en común, explican por qué el ordenamiento jurídico no puede obligar legítimamente a adquirir determinados conocimientos o habilidades para emprender actividades riesgosas, pero poseyéndose estos, no existe ninguna razón plausible -desde el punto de vista de una adecuada mantención de intereses jurídicamente protegidos- para no aplicarlos al momento de actuar ${ }^{21}$.

Ahora bien, especialmente relevante para la distinción entre riesgos desaprobados y tolerados por el Derecho (en el sentido de los delitos culposos de homicidio y lesiones) son las múltiples normas de conducta que protegen de un modo inmediato la vida y salud individual. Estas normas se encuentran en el denominado "orden primario" y nos indican qué comportamientos están permitidos o prohibidos, teniendo en cuenta la conservación de dichos bienes jurídicos ${ }^{22}$.

Existen importantes normas de conducta que emanan de instancias estatales y que contenidas básicamente en leyes y reglamentos- facilitan la distinción entre riesgos jurídicamente desaprobados y tolerados. Normas extrapenales de este tipo se encuentran, por ejemplo, en la Ley del Tránsito o en los reglamentos en materia de fabricación de alimentos y productos farmacéuticos ${ }^{23}$. Estos cuerpos normativos contienen programas de minimización de peligros y -en la medida que pretendan evitar justamente aquella situación que ha conducido al resultado típico- permiten concluir si determinadas creaciones de riesgo están permitidas o no por el Derecho. Por regla general, el cumplimiento de tales normas excluirá eo ipso la generación de un riesgo jurídicamente desaprobado ${ }^{24}$; el riesgo que

imprudente - Fundamentos para la determinación de lo injusto imprudente en los delitos activos de resultado, Barcelona: Atelier, 2007, pp. 279 y ss., así como PAREDES, José Manuel, El riesgo permitido en Derecho penal (Régimen jurídico-penal de las actividades peligrosas), Madrid: Centro de publicaciones de la Secretaría General Técnica del Ministerio de Justicia e Interior, 1995, pp. 331 y ss.

${ }^{20}$ Cfr. entre otros MAÑALICH, Juan, "La imprudencia como estructura de imputación", Revista de Ciencias Penales, Sexta Época, Vol. XLII, N. 3 (2015), pp. 13-35, p. 22 ("Puesto en terminología más tradicional, ello significa que la infracción de la exigencia de cuidado tiene que ser determinada bajo la adopción de un baremo individualizador y no generalizador", la cursiva aparece en el original); MUÑOZ, Francisco; GARCÍA, Mercedes, Derecho penal Parte General, $9^{\text {a }}$ edición, Valencia: Tirant lo Blanch, 2015, p. 307; VAN WEEZEL, Alex, "Parámetros para el enjuiciamiento de la infracción al deber de cuidado en los delitos imprudentes", Revista Chilena de Derecho, Vol. 26 № 2 (1999), pp. 323-336, p. 333. Para el Derecho alemán véase, por todos, KASPAR, Johannes, "Grundprobleme der Fahrlässigkeitsdelikte", JuS (2012), pp. 16-21, p. 20.

${ }^{21}$ Cfr. MURMANN, Uwe, "Zur Berücksichtigung besonderer Kenntnisse, Fähigkeiten und Absichten bei der Verhaltensnormkonturierung”, en: PUTZKE, Holm et al (Editores), Strafrecht zwischen System und Telos Festschrift für Rolf Dietrich Herzberg zum siebzigsten Geburtstag am 14. Februar 2008, Tübingen: Mohr Siebeck, 2008, pp. 123-140, pp. 129, 133 y s.

${ }^{22}$ MURMANN, Grundkurs, cit. nota n ${ }^{\circ} 10, \S 23$, número marginal 46.

${ }^{23}$ Véase el Reglamento sanitario de los alimentos (Decreto 977/96 del Ministerio de Salud, publicado en el Diario Oficial el 13.05.1997) y el Reglamento del sistema nacional de control de los productos farmacéuticos de uso humano (Decreto 3/10 del Ministerio de Salud, publicado en el Diario Oficial el 25.06.2011).

${ }^{24}$ Cfr. LENCKNER, "Technische Normen", cit. nota $\mathrm{n}^{\circ}$ 6, p. 494; de acuerdo con él HERZBERG, Rolf Dietrich, Die Verantwortung für Arbeitsschutz und Unfallverhütung im Betrieb, Köln: Carl Heymanns, 1984, p. 159; SATZGER, Die Europäisierung des Strafrechts - Eine Untersuchung zum Einfluß des Europäischen Gemeinschaftsrechts auf das deutsche Strafrecht, Köln: Carl Heymanns, 2001, p. 610. Para la doctrina, si la norma extrapenal buscaba evitar precisamente aquella situación de riesgo que ha conducido al resultado típico en el caso concreto (más en detalle sobre la "identidad de riesgo" en el contexto de las normas extrajurídicas 
Polít. crim. Vol. 13, № 25 (Julio 2018) Art. 11, pp. 387-444.

[http://www.politicacriminal.c1/Vol_13/n_25/Vol13N25A11.pdf]

subsista pese a la observancia de la norma habrá de ser calificado como tolerado (cualquier otra conclusión haría absurda la disposición extrapenal) ${ }^{25}$. Por el contrario, la infracción de una norma extrapenal llevará generalmente a afirmar la creación de un riesgo desaprobado ${ }^{26}$. Empero, un gran número de reglas extrapenales prescinden de regular en detalle la conducta de sus destinatarios y se limitan a contener fórmulas globales que solo positivizan el principio neminem laedere ${ }^{27}$. Al faltar exigencias de conducta concretas, no resulta posible deducir de tales reglas cuáles son los riesgos tolerados en cada caso. Pero, además, existen innumerables situaciones de peligro creadas por múltiples formas de conductas, respecto a las cuales el Estado no ha dictado norma de comportamiento alguna -ni siquiera a través de fórmulas globales-, que permita distinguir entre riesgos permitidos y desaprobados. En estos casos, resulta especialmente útil, para facilitar la distinción, recurrir a normas de conducta dictadas por instancias no estatales, es decir, a reglas extrajurídicas (a continuación, infra 2).

infra 3.1. y especialmente 5.1.2.), el único supuesto en donde la conducta que se ajusta a la reglamentación extrapenal crearía una peligro jurídicamente desaprobado se presentaría cuando tal reglamentación está obsoleta técnicamente o adolece de un déficit notorio como mecanismo de reducción de riesgos (en este sentido GROßE VORHOLT, André, Behördliche Stellungnahmen in der strafrechtlichen Produkthaftung - Zur Konkretisierung von Sorgfaltspflichten bei Risikoentscheidungen, Baden-Baden: Nomos, 1997, p. 170; MAYER, Michael, Strafrechtliche Produktverantwortung bei Arzneimittelschäden - Ein Beitrag zur Abgrenzung der Verantwortungsbereiche im Arzneiwesen aus strafrechtlicher Sicht, Berlin: Springer, 2008, p. 276; VOGEL, “§ 15 Vorsätzliches und fahrlässiges Handeln", cit. nota $n^{\circ} 15$, número marginal 221). Sin embargo, la excepción anterior difícilmente puede ser aceptada: la obsolescencia técnica de una regla extrapenal, o el supuesto error de que puede adolecer desde el punto de vista de un eficaz control de peligros, no conduce al término de su vigencia ni, en consecuencia, a la supresión de su efecto excluyente del carácter desaprobado jurídicamente de la conducta (cfr. HECKMANN, Dirk, Geltungskraft und Geltungsverlust von Rechtsnormen - Elemente einer Theorie der autoritativen Normengeltungsbeendigung, Tübingen: Mohr Siebeck, 1997, p. 466). Las reglamentaciones extrapenales, que solo adquieren vigencia a través de una serie de actos formales (en el caso de la ley: aprobación a través del Parlamento, promulgación, publicación, etc.) no pierden aquella a través de meras circunstancias fácticas, como, por ejemplo, la obsolescencia técnica de la regulación (cfr. HECKMANN, Dirk, Geltungskraft und Geltungsverlust von Rechtsnormen - Elemente einer Theorie der autoritativen Normengeltungsbeendigung, Tübingen: Mohr Siebeck, 1997, p. 471). Si un catálogo estatal de reducción de riesgos se estima insatisfactorio, jamás puede ser corregido a través de la imposición de una pena, sino que ha de ser derechamente eliminado a través de los órganos colegisladores competentes (FRISCH, Wolfgang, Verwaltungsakzessorietät und Tatbestandsverständnis im Umweltstrafrecht Zum Verhältnis von Umweltverwaltungsrecht und Strafrecht und zur strafrechtlichen Relevanz behördlicher Genehmigungen, Heidelberg: Müller, 1993, p. 9).

${ }^{25}$ Cfr. FRISCH, Tatbestandsmäßiges Verhalten, cit. nota ${ }^{\circ}$ 10, p. 92; GARRIDO, Mario, Derecho penal Parte general, Tomo II, $4^{\text {a }}$ edición, Santiago: Editorial Jurídica de Chile, p. 218. Por lo demás, como las normas de sanción de los delitos culposos de homicidio y lesiones forman parte de un Derecho de carácter accesorio, que busca reafirmar la vigencia de deberes jurídicos (lesionados) protectores de la vida y la salud individual, tales normas no pueden desatender lo estatuido en el orden primario extrapenal, y la observancia o no de este por parte de los ciudadanos.

${ }^{26}$ Bajo el presupuesto de que las circunstancias de la conducta objeto de enjuiciamiento coincidan con la constelación fáctica abarcada por la regla extrapenal, la infracción de esta no creará riesgos desaprobados únicamente si el sujeto actuante adopta medidas compensatorias que impidan el surgimiento de un riesgo base residual más alto que el que hubiera aparecido de haberse acatado la regla (en este sentido, por ejemplo, GROßE VORHOLT, Behördliche Stellungnahmen, cit. nota ${ }^{\circ}$ 24, p. 169).

${ }^{27}$ Cfr. GARRIDO, Derecho penal, cit. nota $\mathrm{n}^{\circ}$ 25, p. 215; WAGNER, Gerhard, "BGB § 823 Schadenersatzpflicht", en: SÄCKER, Franz Jürgen et al (Editores), Münchener Kommentar zum Bürgerlichen Gesetzbuch, Tomo 5, 6ª edición, München: C. H. Beck, 2013, número marginal 360. 
CONTRERAS, Lautaro. "Reglas extrajurídicas y creaciones de riesgos toleradas o desaprobadas en los delitos culposos de homicidio y lesiones".

\section{Cuestiones generales sobre las reglas extrajurídicas}

\subsection{Concepto de reglas extrajurídicas. Formas que pueden adoptar y funciones}

La expresión reglas extrajurídicas abarca la más variada gama de "reglas del arte", "prácticas", "protocolos", "normas", "usos", "directrices", "guías", "recomendaciones", etc., todas de naturaleza privada o no estatal, que regulan los procedimientos a desarrollar en actividades profesionales o técnicas determinadas, teniendo en consideración ciertos conocimientos empíricos y grados de exigibilidad usuales ${ }^{28}$. Ejemplos de tales reglas podemos encontrarlos fácilmente en el ámbito del ejercicio de la medicina ${ }^{29}$ y en el contex to de muchas otras actividades donde las formas de proceder correctamente no están reguladas en programas normativos estatales, o lo están solo de un modo general: la instalación de redes de electricidad o gas, la elaboración de alimentos procesados, los trabajos de limpieza o reparación realizados en altura, la mantención de autobuses o aeronaves, la realización de actividades de salvamento, etc.; las reglas que organizan estas tareas se transmiten a través de la formación o capacitación en determinadas áreas y su conocimiento se garantiza a través de exámenes y controles ${ }^{30}$. Para la doctrina, el concepto reglas extrajurídicas incluye no solo directrices para guiar la ejecución de labores profesionales o técnicas, sino también hojas informativas sobre el manejo de ciertas sustancias, así como las advertencias escritas con que se acompañan muchos productos ${ }^{31}$.

Para referirse a las normas no estatales que regulan los procedimientos a desarrollar en actividades profesionales o técnicas, o las formas de manejo de sustancias o productos, es preferible utilizar el término reglas extrajurídicas antes que el de reglas de la técnica. Este último concepto es una especie dentro del género que abarca el primero, y se refiere únicamente a aquellas instrucciones -en el ámbito de los oficios manuales o de la industriasobre formas de actuar en el contexto de la construcción o utilización de equipos técnicos, aparatos, máquinas, productos, edificaciones o similares ${ }^{32}$. Por eso, la expresión reglas de la

\footnotetext{
${ }^{28}$ Cfr. ESTEVE, José, Técnica, riesgo y Derecho - Tratamiento del riesgo tecnológico en el Derecho ambiental, Barcelona: Ariel, 1999, p. 156; FRISCH, Tatbestandsmäßiges Verhalten, cit. nota ${ }^{\circ}$ 10, p. 101 y s. En la doctrina alemana se emplea con cierta frecuencia la expresión "normas del tráfico" ("Verkehrsnormen") para referirse a las reglas extrajurídicas (así, por ejemplo, BURGSTALLER, Manfred, Das Fahrlässigkeitsdelikt im Strafrecht - Unter besonderer Berücksichtigung der Praxis in Verkehrssachen, Wien: Manzsche Verlags- und Universitätsbuchhandlung, 1974, pp. 50 y ss.; MURMANN, Grundkurs, cit. nota n ${ }^{\circ}$ 10, § 23, número marginal 48; ROXIN, Strafrecht, cit. nota n 2 , § 24, números marginales 18 y siguientes).

${ }^{29}$ Sobre el papel de los protocolos y las guías de actuación clínica en el Derecho penal de la medicina, entre otros, detalladamente GUÉREZ, El tratamiento médico, cit. nota no 15, pp. 149 y ss. Para el ámbito del Derecho civil véase GALÁN, Julio, Responsabilidad civil médica, $3^{\mathrm{a}}$ edición, Cizur Menor: Civitas, 2011, pp. 169 y ss. ${ }^{30}$ Cfr. FRISCH, Tatbestandsmäßiges Verhalten, cit. nota ${ }^{\circ} 10$, p. 102.

${ }^{31}$ En este sentido, entre otros, MIKUS, Rudolf, Die Verhaltensnorm des fahrlässigen Erfolgsdelikts, Berlin: Duncker \& Humblot, 2002, p. 98.

${ }^{32}$ Así MARBURGER, Peter, "Die haftungs- und versicherungsrechtliche Bedeutung technischer Regeln", VersR (1983), 597-608, p. 598. Un concepto de regla de la técnica similar al expuesto se puede encontrar en TRATZ, Stefan, Die zivilprozessuale Bedeutung der Regeln der Technik, Würzburg: sin editorial, 2001, p. 23. En Alemania el Derecho positivo emplea tres conceptos distintos para referirse a la evolución técnica y la incorporación de esta en el cuidado debido: reglas de la técnica generalmente reconocidas ("allgemein anerkannten Regeln der Technik"), estado de la técnica ("Stand der Technik") y estado de la ciencia y de la técnica ("Stand von Wissenschaft und Technik"). Las reglas de la técnica generalmente reconocidas aluden a los procedimientos de control de peligros que son conocidos por los profesionales y técnicos del respectivo
} 
Polít. crim. Vol. 13, № 25 (Julio 2018) Art. 11, pp. 387-444.

[http://www.politicacriminal.cl/Vol_13/n_25/Vol13N25A11.pdf]

técnica no incluye disposiciones extrajurídicas tan trascendentales como las reglas del arte médico $^{33}$. Pero, además, el término regla extrajurídica permite -de una mejor forma que el concepto regla de la técnica- destacar la idea de que los programas no estatales de minimización de riesgos no integran el ordenamiento jurídico objetivo ${ }^{34}$. Sobre esto se volverá en detalle un poco más adelante (infra 2.3.).

Las reglamentaciones extrajurídicas pueden existir como reglas de la experiencia transmitidas verbalmente, tal como ha ocurrido durante siglos en el ámbito de los procedimientos técnicos de ciertos oficios manuales ${ }^{35}$. Hoy en día, empero, muchas de las reglas extrajurídicas son desarrolladas en el seno de instituciones normativas no estatales nacionales o extranjeras- y formalizadas por escrito (reglamentaciones extrajurídicas codificadas $)^{36}$. Al respecto, ha de destacarse la labor desarrollada en Chile por el Instituto

sector, considerados por estos como correctos y, en consecuencia, aplicados. No basta con que la teoría se haya manifestado a favor de tales procedimientos de control en publicaciones técnicas o científicas, o que los mismos sean enseñados en universidades o institutos; es indispensable, además, que se hayan puesto en práctica en el correspondiente sector y se hayan mostrado como eficaces como mecanismos de minimización de peligros (véase BOREAN, Las reglas técnicas, cit. nota $\mathrm{n}^{\circ}$ 2, pp. 91 y ss; ESSER, Robert; KEUTEN, Nils Christian, "Strafrechtliche Risiken am Bau - Überlegungen zum Tatbestand der Baugefährdung ( 319 StGB) und seinem Verhältnis zu §§ 222, 229 StGB”, NStZ (2011), pp. 314-322, p. 317; OSSANDÓN, María Magdalena, La formulación de tipos penales - Valoración crítica de los instrumentos de técnica legislativa, Santiago: Editorial Jurídica de Chile, 2009, p. 246 y s.; WOLFF, Hagen, “\$ 319 StGB Baugefährdung”, en: LAUFHÜTTE, Heinrich Wilhelm et al (Editores), Leipziger Kommentar Strafgesetzbuch, Tomo 11, 12 a edición, Berlin: De Gruyter, 2008, número marginal 12). A diferencia de las reglas técnicas generalmente reconocidas, el estado de la técnica y el estado de la ciencia y de la técnica consideran no solo los métodos probados en la práctica y que han dado buenos resultados, sino también los conocimientos más nuevos en el campo de la técnica y de la ciencia, en la medida que aparezca asegurada su aptitud objetiva para controlar peligros sobre la base de pruebas experimentales (MARBURGER, Peter, Die Regeln der Technik im Recht, Köln: Heymann, 1979, p. 439). Crítico respecto de la forma en que la legislación alemana utiliza los conceptos de reglas de la técnica generalmente reconocidas, estado de la técnica y estado de la ciencia y de la técnica se manifiesta SCHÜNEMANN, "Las reglas de la técnica", cit. nota $n^{\circ}$ 3, p. 338; de acuerdo con él, OSSANDÓN, María Magdalena, La formulación de tipos penales - Valoración crítica de los instrumentos de técnica legislativa, Santiago: Editorial Jurídica de Chile, 2009, p. 247 (de otra opinión HOYER, Andreas, "Erlaubtes Risiko und technologische Entwicklung", ZStW 121 (2009), pp. 860-881, pp. 868 y ss.).

${ }_{33}$ Decididamente a favor de la diferenciación entre los conceptos reglas de la técnica y reglas del arte médico MARBURGER, Die Regeln, cit. nota $n^{\circ} 32$, p. 310. Un concepto amplio de norma técnica, que incluye también las reglas del arte médico es defendido por ESTEVE, Técnica, cit. nota $\mathrm{n}^{\circ} 28$, pp. 156 y ss.; de acuerdo con Esteve se muestra OSSANDÓN, La formulación de tipos, cit. nota n 32, p. 239 y s.

${ }^{34}$ No se comparte el (tan) amplio entendimiento de la expresión "reglas técnicas", defendido en MAYER; VERA, "Caso Pinzas", cit. nota $\mathrm{n}^{\circ}$ 2, p. 154, donde se afirma: "[Las] reglas de la técnica constituyen pautas generales de conducta, tipificadas a nivel normativo (leyes, reglamentos, decretos, instrucciones, etc.) o consuetudinario, que en su enunciado expresan deberes de cuidado genérico aplicables a las relaciones intersubjetivas que se verifican en el tráfico". El alcance que estos autores le dan al concepto "reglas de la técnica" es demasiado inespecífico y coloca en un mismo plano normas extrapenales y extrajurídicas, de naturaleza esencialmente distinta. Ha de reconocerse, en todo caso, que en el ámbito jurídico hispanoamericano es frecuente el empleo del término "regla técnica" como sinónimo de "deber de cuidado" o "deber de conducta" (muy evidente, por ejemplo, en CORCOY, El delito imprudente, cit. nota n o 2, pp. 103 y s., 112 y s.).

${ }^{35}$ Así ALEXANDER, Thorsten, Die strafrechtliche Verantwortlichkeit für die Wahrung der Verkehrssicherungspflichten in Unternehmen, Herbolzheim: Centaurus, 2005, p. 90; MARBURGER, "Die haftungs- und versicherungsrechtliche Bedeutung", cit. nota $\mathrm{n}^{\mathrm{o}} 32$, p. 598.

${ }^{36}$ Las reglamentaciones extrajurídicas codificadas son conocidas en Alemania bajo la expresión "Regelwerke" (una definición y crítica de este concepto puede encontrarse en HERSCHEL, Wilhelm, "Regeln der Technik", NJW (1968), pp. 617-623, p. 618 (también nota 26)). 
CONTRERAS, Lautaro. "Reglas extrajurídicas y creaciones de riesgos toleradas o desaprobadas en los delitos culposos de homicidio y lesiones".

Nacional de Normalización (en adelante, indistintamente "INN"), fundación de Derecho privado creada en el año 1973 por la Corporación de Fomento de la Producción, con el objeto de desarrollar y administrar los procesos de normalización técnica en nuestro país. Hasta la fecha, el INN ha emitido -a través de un procedimiento de génesis normativa regulado con bastante detalle- más de 3.000 reglas técnicas en diversas materias; estas reglas se denominan normas chilenas ${ }^{37}$. Por otra parte, existen numerosas entidades extranjeras no estatales, que elaboran reglamentaciones escritas con pautas de comportamiento, estimadas en Chile como relevantes por diversos sectores técnicos o profesionales ${ }^{38}$.

Las reglas extrajurídicas persiguen no solamente la racionalización, simplificación y unificación de procesos técnicos (normas de racionalización), sino también -y en esto radica su gran importancia para fijar la medida del riesgo tolerado en los delitos culposos de homicidio y lesiones corporales- la eliminación o disminución hasta umbrales tolerables de peligros para la vida o salud individual (normas de seguridad) ${ }^{39}$.

\subsection{Reglas extrajurídicas de seguridad y delitos imprudentes del Título $\mathrm{X}$ del Libro II del Código Penal}

Precisamente las reglas extrajurídicas que persiguen la mantención de los bienes jurídicos vida y salud individual cobran relevancia en los delitos culposos de homicidio y lesiones corporales de los arts. 490 y 491 del Código Penal, para efectos de fijar si se ha sobrepasado o no el umbral del riesgo tolerado. En cambio, es más que dudoso que los programas no estatales de minimización de peligros desempeñen algún papel a propósito de la norma de sanción del art. 492 del mismo código. Este precepto alude en su inc. $1^{\circ}$ a la infracción de "reglamentos", esto es, a la inobservancia de "reglas sociales obligatorias establecidas con carácter permanente por la autoridad, y sancionadas por la fuerza" (= normas extrapenales $)^{40}$.

\footnotetext{
${ }^{37}$ Acerca del origen, funciones y mecanismos de funcionamiento del INN véase MIRANDA, Patricia, El sistema jurídico de la técnica: las normas técnicas, Memoria para optar al grado de Licenciado en Ciencias Jurídicas y Sociales, Universidad de Chile, Santiago de Chile, 2003, pp. 121 y ss. El proceso de génesis de las normas chilenas está regulado en la Norma Chilena (en adelante, indistintamente "NCh") 1-2011, denominada "Normas Chilenas NCh - Definiciones y procedimiento para su estudio y mantención".

${ }^{38}$ Solo a modo ejemplar: la American Heart Association - AHA (Asociación Americana del Corazón) y el American College of Cardiology - ACC (Colegio Americano de Cardiología) han elaborado en conjunto guías médicas para el diagnóstico y tratamiento de enfermedades al corazón, que se tienen a la vista en la práctica médica chilena (cfr. http://www.fundacioncalvomackenna.cl/noticia-09/, visitado el 12.06.2017); el Deutsches Institut für Normung - DIN (Instituto Alemán de Normalización) elabora (entre muchísimas otras reglas) normas técnicas que regulan las instalaciones de gas, y que pueden resultar aplicables en Chile en virtud de lo que dispone el inciso $2^{\circ}$ del art. $7^{\circ}$ del Reglamento de instalaciones interiores y medidores de gas (Decreto Supremo N. ${ }^{\circ} 66$, de 2 de febrero de 2007, publicado en el Diario Oficial el 19.07.2007).

${ }^{39}$ Sobre las distintas funciones que pueden desplegar las reglas extrajurídicas véase en detalle MARBURGER,

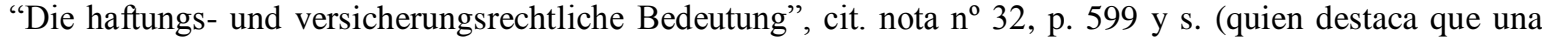
determinada reglamentación extrajurídica puede cumplir simultáneamente funciones de racionalización y de seguridad); MÜLLER-FOELL, Martina, Die Bedeutung technischer Normen für die Konkretisierung von Rechtsvorschriften, Heidelberg: Müller, 1987, pp. 73 y ss. Véase también IZQUIERDO, Manuel, La seguridad de los productos industriales - Régimen jurídico-administrativo y protección de los consumidores, Madrid:

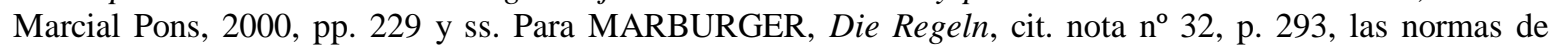
seguridad concretan en el ámbito de la técnica el principio jurídico general del neminem laedere.

${ }^{40}$ Definición incluida en el considerando $5^{\circ}$ de la sentencia de reemplazo pronunciada por la Corte Suprema el 15.11.1999 en causa ROL 3192-1999 (redacción a cargo de Cury); cfr. además considerando $7^{\circ}$ de la sentencia
} 
Polít. crim. Vol. 13, № 25 (Julio 2018) Art. 11, pp. 387-444.

[http://www.politicacriminal.cl/Vol_13/n_25/Vol13N25A11.pdf]

Este concepto de "reglamentos", desarrollado por una parte de la jurisprudencia y doctrina chilenas, parece ser la consecuencia obligada de la aplicación del elemento sistemático de interpretación de la ley penal. Ciertamente, las múltiples ocasiones en que el Código emplea la voz "reglamentos" lo hace aludiendo a normas jurídicas generales de rango inferior al legal (v. gr., arts. 80 inc. $2^{\circ}, 146$ inc. $3^{\circ}, 256,281$ inc. $1^{\circ}, 288,320$ y 322 ) o a preceptos obligatorios dictados por la autoridad competente (v. gr., arts. $32,221,317$ inc. $2^{\circ}, 329,482$ inc. $2^{\circ}, 494$ $\mathrm{N}^{\circ} 17$ y $495 \mathrm{~N}^{\circ} 2$ ); en ninguna de tales oportunidades se pretende hacer mención a reglas de naturaleza privada o no estatal, como lo son las reglas extrajurídicas. El que el inc. $1^{\circ}$ del art. 492 del Código Penal solo se aplique frente a la infracción de disposiciones extrapenales tiene una consecuencia importante, puesto que entonces los comportamientos que se han desviado de lo previsto en reglamentaciones extrajurídicas - provocando un resultado lesivo, solo podrán ser captados penalmente cuando haya existido "culpa grave" por parte del sujeto (art. 490), o "culpa leve", y en este último caso únicamente en la medida que el agente sea un profesional de la salud (art. 491) ${ }^{41}$.

Ahora bien, los presupuestos materiales bajo los cuales las reglamentaciones extrajurídicas de seguridad permitirían fijar la medida del riesgo tolerado para efectos de los arts. 490 y 491 del Código Penal serán tratados con detalle en la sección siguiente (infra 3); antes, corresponde detenernos en la naturaleza de tales reglamentaciones (a continuación, infra 2.3.).

\subsection{Naturaleza de las reglas extrajurídicas}

\subsubsection{El carácter no vinculante de las reglamentaciones extrajurídicas}

En la doctrina y jurisprudencia, tanto nacional como comparada, existe consenso en que las reglamentaciones extrajurídicas -a diferencia de las normas extrapenales- no integran el Derecho objetivo y, en consecuencia, no contienen prohibiciones o mandatos vinculantes

del Tribunal Constitucional de fecha 10.09.2015, ROL 2.716-2014. Para Bustos los reglamentos son todas aquellas normas jurídicas dictadas por la autoridad para regular un determinado ámbito (BUSTOS, Juan, $E l$ delito culposo, Santiago: Editorial Jurídica de Chile, 1995, p. 47; de acuerdo con la opinión de este autor se manifiesta el Sexto Tribunal de Juicio Oral en lo Penal de Santiago en causa RUC 1001141178-4, RIT 2582013 (considerando $271^{\circ}$ ), donde se juzgó la responsabilidad por las muertes ocasionadas en el incendio del Centro de Detención Preventiva de San Miguel ocurrido el 08.12.2010). Por su parte, Garrido indica que bajo la expresión "reglamentos" han de incluirse los reglamentos propiamente tales, la Constitución y la ley (GARRIDO, Derecho Penal, cit. nota n 25 , p. 174, sin precisar, no obstante, de qué manera se pueden inferir de la Constitución expectativas de conducta idóneas para la protección de bienes juridicos). También en la doctrina española previa al Código Penal de 1995 se interpretó la expresión "reglamentos", que empleaba el art. 565 del antiguo Código Penal (antecedente de nuestro art. 492), como "conjunto de normas jurídicas" (véase

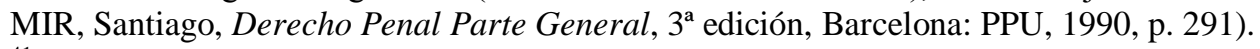

${ }^{41}$ Sobre el grado de cuidado exigido en los arts. 490, 491 y 492, todos del Código Penal, de manera detallada, véase HERNÁNDEZ, Héctor, “Art. 2o”, en: COUSO, Jaime; HERNÁNDEZ, Héctor (Editores), Código Penal comentado, Santiago de Chile: Legal Publishing, 2011, pp. 105-123, pp. 115 y ss. A favor de entender la expresión "negligencia culpable" que emplea el art. 491 como "culpa grave", entre otros, BUSTOS, El delito culposo, cit. nota $\mathrm{n}^{\circ} 40$, p. 55; de acuerdo con él, recientemente, REYES, Ítalo, "Una aproximación a la imputación a título de imprudencia en el Código Penal chileno", Revista de Derecho de la Pontificia Universidad Católica de Valparaíso, XLVII, $2^{\circ}$ semestre (2016), pp. 245-278, p. 275. 
CONTRERAS, Lautaro. "Reglas extrajurídicas y creaciones de riesgos toleradas o desaprobadas en los delitos culposos de homicidio y lesiones".

para los individuos ${ }^{42}$. La principal razón que se esgrime en contra de la normatividad de los programas privados de reducción de riesgos es su déficit de legitimación. Ciertamente, las instancias o personas que elaboran tales programas (gremios de normalización, colegios profesionales, autores de publicaciones científicas o técnicas donde se fijan pautas de actuación, etc.) carecen de la competencia para establecer de un modo obligatorio -en el marco del conflicto que subyace en toda norma de conducta entre los intereses en la conservación de bienes jurídicos y los intereses en el ejercicio de la libertad de acción- la medida del riesgo permitido ${ }^{43}$. Debido a tal falta de competencia normativa, no cabe inferir del acatamiento de reglas extrajurídicas la generación de (únicamente) peligros tolerados por el Derecho; ni de su inobservancia la creación de riesgos jurídicamente desaprobados.

Además, las reglamentaciones extrajurídicas no pueden ser consideradas como costumbre y, en consecuencia, no corresponde integrarlas como tal fuente del Derecho en las prescripciones del ordenamiento jurídico objetivo ${ }^{44}$. La costumbre exige siempre la práctica

${ }^{42}$ Véase Dictamen N. ${ }^{\circ}$ 64.893, de 09.10.2013, de la Contraloría General de la República; BGHZ, 139, 16, 19 y s.; ALEXANDER, Die strafrechtliche Verantwortlichkeit, cit. nota n ${ }^{\circ} 35$, p. 90; BACHMANN, Gregor, Private Ordnung, Tübingen: Mohr Siebeck, 2006, p. 335; BOREAN, Las reglas técnicas, cit. nota n 2, p. 76; BURGSTALLER, Das Fahrlässigkeitsdelikt, cit. nota n ${ }^{\circ}$ 28, p. 51; CORDERO, Luis, Lecciones de Derecho administrativo, $2^{\mathrm{a}}$ edición, Santiago de Chile: Legal Publishing Chile, 2015, p. 165 y s.; ELSTER, Tobias, Ärztliche Leitlinien in der vertraglichen Arzthaftung - Eine Untersuchung materiell-rechtlicher und prozessualer Aspekte unter besonderer Berücksichtigung des medizinischen Standards, Frankfurt am Main: Peter Lang, 2004, pp. 90 y ss.; ESSER; KEUTEN, "Strafrechtliche Risiken”, cit. nota no 32, p. 317; ESTEVE, Técnica, cit. nota $\mathrm{n}^{\circ} 28$, pp. 165 y ss., 171; GROßE VORHOLT, Behördliche Stellungnahmen, cit. nota $\mathrm{n}^{\circ} 24$, p. 108; HERSCHEL, "Regeln der Technik", cit. nota n 36, p. 617; JAKOBS, Strafrecht, cit. nota n 2, Sección 7, número marginal 44; LENCKNER, “Technische Normen”, cit. nota nº 6, p. 494 y s.; MARBURGER, Peter, "Herstellung nach zwingenden Rechtsvorschriften als Haftungsausschlußgrund im neuen Produkthaftungsrecht”, en: LEßMANN, Herbert et al (Editores), Festschrift für Rudolf Lukes zum 65 Geburtstag, Köln: Carl Heymanns, 1989, pp. 97-119, p. 102; MIKUS, Die Verhaltensnorm, cit. nota n ${ }^{\circ}$ 31, p. 99; NICKLISCH, Fritz, “Technische Regelwerke -Sachverständigengutachten im Rechtssinne?”, NJW (1983), pp. 841-850, p. 841; OSSANDÓN, La formulación de tipos, cit. nota n 32, p. 241; ROJAS, Christian, "Las implicancias jurídicas de la normalización técnica. Sus antecedentes, proyección y las manifestaciones para el caso de Chile", Revista de Derecho Universidad Católica del Norte, Año 16 - º 1 (2009), pp. 91-133, p. 119 y s.; SCHÜRER-MOHR, Wiebke, Erlaubte Risiken: Grundfragen des «erlaubten Risikos» im Bereich der Fahrlässigkeitsdogmatik, Frankfurt am Main: Peter Lang, 1998, p. 187; TAUPITZ, Jochen, "Verbindlichkeit unterschiedlicher Leitlinien", en: Arbeitsgemeinschaft Rechtsanwälte im Medizinrecht e.V. (Editores), Dokumentation und Leitlinienkonkurrenz - die Verschriftlichung der Medizin, Berlin: Springer, 2007, pp. 101121, p. 104; VEIT, Barbara, Die Rezeption technischer Regeln im Strafrecht und Ordnungswidrigkeitenrecht unter besonderer Berücksichtigung ihrer verfassungsrechtlichen Problematik, Düsseldorf: Werner, 1989, p. 13; WAGNER, Gerhard, "BGB $\S 823$ Schadenersatzpflicht”, en: SÄCKER, Franz Jürgen et al (Editores), Münchener Kommentar zum Bürgerlichen Gesetzbuch, Tomo 6, $7^{\mathrm{a}}$ edición, München: C. H. Beck, 2017, número marginal 489.

${ }^{43}$ En este sentido FRISCH, Tatbestandsmäßiges Verhalten, cit. nota $n^{\circ} 10$, p. 102; de acuerdo con él BOSCH, Nikolaus, Organisationsverschulden in Unternehmen, Baden-Baden: Nomos, 2002, p. 443.

${ }^{44}$ Se manifiestan en contra de asignar a las reglas extrajurídicas fuerza vinculante por la vía de estimarlas como costumbre BOREAN, Las reglas técnicas, cit. nota n² 2, pp. 74 y ss.; LENCKNER, "Technische Normen”, cit. nota $\mathrm{n}^{\circ}$ 6, p. 495; MARBURGER, Die Regeln, cit. nota $\mathrm{n}^{\mathrm{o}}$ 32, pp. 337 y ss.; MAYER, Strafrechtliche Produktverantwortung, cit. nota $\mathrm{n}^{\circ}$ 24, p. 275; MIKUS, Die Verhaltensnorm, cit. nota $\mathrm{n}^{\circ} 31$, pp. 99 y ss. (destacando, expresamente, que no solo las reglas técnicas, sino que el conjunto de reglamentaciones extrajurídicas -incluyendo las recomendaciones y advertencias con que se acompañan muchos productos- no pueden ser calificadas de costumbre); SCHÄFER, Karl-Wilhelm, Das Recht der Regeln der Technik, Köln: sin editorial, 1965, p. 118 y s.; SPINDLER, Gerald, Unternehmensorganisationspflichten - Zivilrechtliche und öffentlichrechtliche Regelungskonzepte, $2^{\mathrm{a}}$ edición, Göttingen: Universitätsverlag Göttingen, 2011, p. 506 y s. 
Polít. crim. Vol. 13, № 25 (Julio 2018) Art. 11, pp. 387-444.

[http://www.politicacriminal.cl/Vol_13/n_25/Vol13N25A11.pdf]

generalizada, uniforme y constante en el tiempo de cierta forma de proceder, realizada con la convicción de que forma parte del Derecho vigente. En lo tocante a las reglas de la técnica, que representan una porción significativa del universo de las limitaciones de peligros extrajurídicas, se ha destacado que normalmente faltará en ellas la manifestación de un uso constante a lo largo del tiempo y que, por eso, no pueden catalogarse como costumbre. Por cierto, el progreso inherente al campo de la técnica hace imperioso que sus reglas se transformen y ajusten de manera continua ${ }^{45}$. Inevitablemente estas reglas devienen obsoletas en algún momento y han de ser modificadas; están condicionadas históricamente. Tratándose de las normas chilenas, la necesidad de adaptarlas al más reciente estado de la técnica se encuentra institucionalizada, recomendándose que sean confirmadas, revisadas o anuladas cada cinco años ${ }^{46}$. Por otra parte, y en lo que concierne a las reglas del arte médico, estas también son permanentemente corregidas y actualizadas, puesto que la velocidad del progreso de la medicina es todavía mayor que el de muchas disciplinas técnicas ${ }^{47}$; por eso, la lex artis tampoco puede incardinarse en la costumbre: falta en ella la expresión de una práctica uniforme y duradera ${ }^{48}$.

El que una ley o reglamento se refiera a los programas no estatales de minimización de riesgos a través del empleo de "cláusulas técnicas", tampoco los convierte en disposiciones vinculantes ${ }^{49}$. La utilización de este mecanismo tiene lugar cuando una norma jurídica dispone que las características de ciertas instalaciones, productos, aparatos, procedimientos, etc. deben ajustarse a "la mejor tecnología disponible", "al estado de la ciencia y de la técnica", "a los conocimientos científicos en la materia", etc. Un ejemplo de empleo de "cláusulas técnicas" en nuestro Derecho se puede encontrar en el art. 71, inc. $2^{\circ}$ número 5, del Reglamento del sistema nacional de control de los productos farmacéuticos de uso humano ${ }^{50}$, conforme al cual el responsable de introducir un medicamento en el mercado tiene que informar permanentemente a la Administración de las condiciones de seguridad de los fármacos, de acuerdo con el "estado de la ciencia y de la técnica" del Reglamento a tal conocimiento no transforma a este en parte integrante del ordenamiento jurídico; el sentido de tal referencia es, simplemente, permitir la concreción del Derecho objetivo a través de elementos o consideraciones extrajurídicos ${ }^{52}$.

De otra opinión posiblemente (no es totalmente claro en su postura) HERSCHEL, "Regeln der Technik", cit. nota $\mathrm{n}^{\circ} 36$, p. 622 .

${ }^{45}$ Así, entre otros, LENCKNER, "Technische Normen", cit. nota n 6, p. 495; de acuerdo con él MIKUS, Die Verhaltensnorm, cit. nota ${ }^{\circ} 31$, p. 100.

${ }^{46}$ Véase sección 7.1 de la NCh1-2011 "Normas Chilenas NCh - Definiciones y procedimiento para su estudio y mantención".

${ }^{47}$ Cfr. PIZARRO, Carlos, La responsabilidad civil médica, Santiago: Legal Publishing Chile, 2017, p. 39 (“Sin duda, la lex artis constituye un parámetro cambiante, en constante evolución, que depende de los conocimientos científicos a la época de ejecución del acto médico").

${ }^{48}$ En este sentido, expresamente, STAUDT, Lea, Medizinische Richt- und Leitlinien im Strafrecht - Eine Untersuchung zur Möglichkeit der Bestimmung der unerlaubten Handlung beim Fahrlässigkeitsdelikt mit Hilfe medizinischer Richt- und Leitlinien, Frankfurt am Main: Peter Lang, 2012, p. 151. Niega también el carácter de costumbre a las reglas del arte médico MIKUS, Die Verhaltensnorm, cit. nota $\mathrm{n}^{\mathrm{o}}$ 31, p. 100. De otra opinión, aparentemente, PIZARRO, La responsabilidad civil, cit. nota $\mathrm{n}^{\circ}$ 47, p. 36.

${ }^{49}$ En este sentido véase HERSCHEL, "Regeln der Technik", cit. nota n 36, p. 620; LENCKNER, "Technische Normen", cit. nota no 6, p. 495 y s. Cfr. también OSSANDÓN, La formulación de tipos, cit. nota n 32, p. 242.

${ }^{50}$ Decreto 3/2010 del Ministerio de Salud, publicado en el Diario Oficial el 25.06.2011.

${ }^{51}$ Sobre el significado del concepto "estado de la ciencia y de la técnica" véase supra nota no 32 .

${ }^{52}$ Cfr. ROJAS, "Las implicancias jurídicas”, cit. nota n 42, p. 123. 
CONTRERAS, Lautaro. "Reglas extrajurídicas y creaciones de riesgos toleradas o desaprobadas en los delitos culposos de homicidio y lesiones".

En suma, las reglamentaciones extrajurídicas de seguridad no representan normas jurídicas, sino reglas privadas de carácter no vinculante. Ellas no pueden ser consideradas fenómenos del Derecho ${ }^{53-54}$.

Los programas no estatales de minimización de riesgos únicamente pueden alcanzar un carácter preceptivo en la medida que el Derecho positivo se remita a ellos, y siempre y cuando la correspondiente remisión sea admisible de acuerdo con los principios constitucionales del Estado de Derecho y democrático ${ }^{55}$. Como veremos a continuación, existen distintas técnicas a través de las cuales el ordenamiento puede aludir a las reglamentaciones extrajurídicas, con la finalidad de dotarlas de fuerza vinculante, a saber: incorporación, remisión estática, remisión dinámica e introducción administrativa.

\subsubsection{La incorporación y la remisión estática}

A través de la técnica de la incorporación, una ley o reglamento reproduce expresamente el texto de un programa no estatal de minimización de riesgos o una parte del mismo, agregándolo al ordenamiento jurídico objetivo ${ }^{56}$. La remisión estática, por su parte, consiste en la referencia que hace el Derecho positivo a una versión concreta de una determinada reglamentación extrajurídica - generalmente la última-, dotándola de fuerza vinculante ${ }^{57}$; un ejemplo lo encontramos en el art. 143 del Reglamento de almacenamiento de sustancias peligrosas $^{58}$, conforme al cual el depósito de ciertos gases en estanques fijos tiene que estar señalizado con el rótulo de seguridad establecido en la norma chilena 1411/4-2001 ${ }^{59}$.

\footnotetext{
${ }^{53}$ Cfr. HERSCHEL, "Regeln der Technik", cit. nota n 36, p. 617 y s.
}

${ }^{54} \mathrm{El}$ que las reglas extrajurídicas no constituyan normas jurídicas tiene relevantes implicancias procesales: su existencia y contenido específico han de ser probados en el respectivo juicio. Acerca de cuál es el medio probatorio idóneo para ello véase MÜLLER-FOELL, Die Bedeutung, cit. nota no 39, pp. 139 y ss.; TRATZ, Die zivilprozessuale Bedeutung, cit. nota ${ }^{\circ} 32$, pp. 129 y ss.

${ }^{55}$ Solo en esa medida las reglas extrajurídicas podrían, por lo demás, ser consideradas como normas sociales obligatorias establecidas con carácter permanente por la autoridad, y cobrar relevancia para fijar los límites entre los riesgos permitidos y desaprobados en el contexto del art. 492, inc. $1^{\circ}$, del Código Penal (véase supra 2.2.).

${ }^{56}$ Sobre la técnica de incorporación véase ÁLVAREZ, Vicente, La normalización industrial, Valencia: Tirant lo Blanch, 1999, pp. 123 y ss.; MÜLLER-FOELL, Die Bedeutung, cit. nota nº 39, pp. 112 y ss.; WEI $\beta$, Holger, Die rechtliche Gewährleistung der Produktsicherheit, Baden-Baden: Nomos, 2008, p. 329.

${ }^{57}$ Sobre la remisión estática véase ÁLVAREZ, La normalización, cit. nota n ${ }^{\circ}$ 56, pp. 126 y ss.; BOREAN, Las reglas técnicas, cit. nota $\mathrm{n}^{\circ} 2$, p. 77; IZQUIERDO, La seguridad, cit. nota $\mathrm{n}^{\circ} 39$, p. 250 (quien prefiere la expresión "reenvío recepticio"); MÜLLER-FOELL, Die Bedeutung, cit. nota n 39, pp. 112 y ss.; OSSANDÓN, La formulación de tipos, cit. nota ${ }^{\circ} 32$, p. 241. En supuestos de remisión estática, la Contraloría General de la República ha declarado que si un reglamento hace referencia a una "norma chilena", esta debe mantenerse a disposición del público en el sitio electrónico del ministerio respectivo, en virtud del principio de publicidad consagrado en el art. $8^{\circ}$ de la Constitución Política de la República (véanse dictámenes 20.050 y 20.062, ambos de fecha 14.03.2016). Sobre la exigencia de publicidad de las reglas extrajurídicas en el marco de las remisiones estáticas véase, por ejemplo, ÁLVAREZ, La normalización, cit. nota $\mathrm{n}^{\circ} 56$, pp. 139 y ss.; MARBURGER, Peter, "Formen, Verfahren und Rechtsprobleme der Bezugnahme gesetzlicher Regelungen auf industrielle Normen und Standards", en: MÜLLER-GRAFF, Peter-Christian (editor), Technische Regeln im Binnenmarkt, Baden-Baden: Nomos, 1991, pp. 27-56, p. 46.

${ }^{58}$ Decreto 43/2016 del Ministerio de Salud, publicado en el Diario Oficial el 29.03.2016.

${ }^{59}$ En nuestro ordenamiento jurídico, las remisiones estáticas también se hacen a reglas extrajurídicas elaboradas en el extranjero (véase, por ejemplo, el art. $8^{\circ}$ del Reglamento de seguridad para las instalaciones de 
Polít. crim. Vol. 13, № 25 (Julio 2018) Art. 11, pp. 387-444.

[http://www.politicacriminal.c1/Vol_13/n_25/Vol13N25A11.pdf]

La constitucionalidad de las fórmulas de incorporación y remisión estática ha sido objeto de especial interés en el Derecho alemán, señalándose que estas no entran en pugna con el principio del Estado de Derecho ni tampoco con el principio democrático ${ }^{60}$. Y es que a través de dichas fórmulas las reglas extrajurídicas solo se convierten en obligatorias -con la consiguiente restricción a la libertad de acción del individuo- en virtud de su total inclusión en la voluntad del Ejecutivo o el Legislativo, no existiendo delegación de potestades públicas a entidades privadas de normalización ${ }^{61}$. Sin perjuicio de ello, las técnicas de incorporación y de remisión estática adolecen de una importante desventaja, puesto que las prescripciones técnicas que pasan a tener fuerza vinculante no pueden adaptarse a un ritmo adecuado a los avances de la ciencia y de las nuevas tecnologías, volviéndose rápidamente obsoletas ${ }^{62}$. Mientras el ordenamiento jurídico no active sus específicos mecanismos de derogación, las prescripciones técnicas desfasadas siguen formando parte del Derecho vigente, por lo que, paradójicamente, puede exigirse su cumplimiento obligatorio ${ }^{63}$. Por este motivo, la utilización de las técnicas de incorporación y de remisión estática suele ser poco frecuente ${ }^{64}$.

\subsubsection{La remisión dinámica}

Otra modalidad a través de la cual el Derecho positivo puede aludir a las reglas extrajurídicas, adquiriendo estas fuerza vinculante, consiste en la remisión dinámica. En ella, la ley o el reglamento no se refiere a una versión concreta de una regla extrajurídica -como acontece en la remisión estática-, sino a la versión vigente en el momento en que la ley o el reglamento tenga que ser aplicado; de este modo, la remisión se hace a un programa no estatal de minimización de riesgos que se irá modificando sucesivamente en el tiempo ${ }^{65}$. En la remisión dinámica, el ordenamiento jurídico pierde el control sobre el contenido de la norma técnica que a él se incorpora, entregándolo por completo a instancias normativas privadas. Un

almacenamiento, transporte y distribución de gas licuado de petróleo y operaciones asociadas, Decreto 108/2013 del Ministerio de Energía, publicado en el Diario Oficial el 12.07.2014).

${ }^{60}$ De acuerdo con el Tribunal Constitucional Federal alemán, el principio del Estado de Derecho obliga a que las limitaciones a la libertad del ciudadano solo pueden realizarse a través o sobre la base de leyes estatales (BVerfGE 64, 208, 214); por otra parte, conforme al principio democrático, la regulación de un ámbito social a través del Derecho objetivo ha de ser siempre la consecuencia de una decisión de voluntad de los órganos legisladores elegidos por el pueblo (BVerfGE 64, 208, 214 y s.).

${ }^{61}$ En este sentido SCHÜNEMANN, "Las reglas de la técnica", cit. nota $n^{\circ} 3$, p. 320; WEI $\beta$, Die rechtliche Gewährleistung, cit. nota ${ }^{\circ}$ 56, p. 329.

${ }^{62}$ Expresamente en este sentido IZQUIERDO, La seguridad, cit. nota n ${ }^{\circ}$ 39, p. 245; ROJAS, "Las implicancias jurídicas", cit. nota ${ }^{\circ} 42$, p. 121.

${ }^{63}$ ESTEVE, Técnica, cit. nota $\mathrm{n}^{\circ} 28$, p. 173 y s. Como la prescripción técnica obsoleta seguirá integrando el ordenamiento jurídico, los riesgos residuales que subsistan pese a su observancia deberán calificarse de peligros jurídicamente tolerados. La obsolescencia técnica de un mecanismo de reducción de riesgos incorporado a una norma jurídica, o al que una norma jurídica se remite de un modo estático, nunca conduce a la pérdida de vigencia de la norma y, en consecuencia, a la supresión de su efecto excluyente del carácter desaprobado de la conducta. Las normas jurídicas, cuya vigencia siempre comienza a través de un acto formal, no pueden perder aquella a través de un mero hecho (la obsolescencia del mecanismo de control de peligros). Cfr. al respecto HECKMANN, Geltungskraft und Geltungsverlust, cit. nota n ${ }^{\circ} 24$, p. 471; véase también supra nota $n^{\circ} 24$.

${ }^{64}$ Cfr. MÜLLER-FOELL, Die Bedeutung, cit. nota no 39, p. 18 y s.

${ }^{65}$ Acerca de las remisiones dinámicas véase, entre otros, ÁLVAREZ, La normalización, cit. nota no 56, pp. 129 y ss.; BOREAN, Las reglas técnicas, cit. nota ${ }^{\circ} 2$, pp. 77 y ss.; ESTEVE, Técnica, cit. nota $\mathrm{n}^{\circ} 28$, pp. 174 y s.; IZQUIERDO, La seguridad, cit. nota n 39 , p. 251; MARBURGER, Die Regeln, cit. nota no 32, pp. 390 y ss.; OSSANDÓN, La formulación de tipos, cit. nota n 32, p. 241. 
CONTRERAS, Lautaro. "Reglas extrajurídicas y creaciones de riesgos toleradas o desaprobadas en los delitos culposos de homicidio y lesiones".

ejemplo de esta fórmula podría encontrarse en el art. 106 de la Ley General de Urbanismo y Construcciones, según el cual los materiales y sistemas a usar en las urbanizaciones y construcciones deberán cumplir con las normas técnicas preparadas por el Ministerio de Vivienda y Urbanismo, sus servicios dependientes o el Instituto Nacional de Normalización. Un pronunciamiento expreso acerca de la constitucionalidad de las remisiones dinámicas puede encontrarse en la jurisprudencia del Tribunal Constitucional Federal alemán. En una sentencia pronunciada el año 1984 el tribunal declaró que tales remisiones eran inconstitucionales, puesto que entran en pugna con los ya mencionados principios del Estado de Derecho y democrático ${ }^{66}$. En efecto, las reglas extrajurídicas de seguridad contienen expectativas de conducta para la eliminación o disminución de peligros; por eso, en ellas siempre subyace una decisión valorativa concerniente a la manera en que la libertad protegida constitucionalmente ha de ser restringida en favor de la mantención de bienes jurídicos ${ }^{67}$. Considerando las implicancias que tiene una decisión semejante para el ejercicio de los derechos fundamentales, esta no puede ser tomada sino a través del titular del poder soberano, en un proceso y en la forma que respete los principios del Estado de Derecho ${ }^{68}$. La técnica de la remisión dinámica, que convierte en Derecho vinculante a reglas extrajurídicas modificables en el tiempo por la mera voluntad de instancias normativas no estatales, implica una delegación fáctica a privados de la decisión de restringir la libertad de acción, inadmisible desde el punto de vista constitucional ${ }^{69}$.

\subsubsection{La introducción administrativa}

En el Derecho chileno existe una técnica particular para dotar de fuerza vinculante a ciertos programas no estatales de minimización de riesgos, a saber: las normas chilenas emanadas del Instituto Nacional de Normalización. Esta técnica consiste en la dictación de un acto administrativo donde se declara que una determinada norma chilena pasa a llamarse "norma chilena oficial" o "norma técnica oficial"70, adquiriendo de este modo fuerza obligatoria". Son varias las leyes y disposiciones de inferior jerarquía a la legal que facultan a la autoridad para incorporar administrativamente normas chilenas al sistema jurídico. Por ejemplo: el art. 111 letra c) del Código Sanitario dispone que las pruebas de calidad realizadas sobre

\footnotetext{
${ }^{66}$ BVerfGE 64, 208, 214 y s. Sobre la inconstitucionalidad de las remisiones dinámicas véase, entre otros, MARBURGER, Die Regeln, cit. nota $\mathrm{n}^{\circ} 32$, pp. 390 y ss.; OSSANDÓN, La formulación de tipos, cit. nota ${ }^{\circ}$ 32, p. 241 y s.; ROJAS, "Las implicancias jurídicas", cit. nota $\mathrm{n}^{\circ}$ 42, p. 122; SCHENKE, Wolf-Rüdiger, "Die verfassungsrechtliche Problematik dynamischer Verweisungen”, NJW (1980), pp. 743-749, pp. 743 y ss.

${ }^{67}$ Cfr. WEI $\beta$, Die rechtliche Gewährleistung, cit. nota n ${ }^{\circ} 56$, p. 330; ver también SCHÜNEMANN, "Las reglas de la técnica", cit. nota ${ }^{\circ} 3$, p. 323.

${ }^{68}$ En este sentido WEI $\beta$, Die rechtliche Gewährleistung, cit. nota $n^{\circ} 56$, p. 330.

${ }^{69}$ Así WEI $\beta$, Die rechtliche Gewährleistung, cit. nota n ${ }^{\circ} 56$, p. 330. En detalle sobre la inconstitucionalidad de la delegación de potestades legislativas a entidades de normalización véase BOREAN, Las reglas técnicas, cit. nota $\mathrm{n}^{\circ} 2$, pp. 71 y ss.

${ }^{70} \mathrm{El}$ art. 1.1.2. de la Ordenanza General de Urbanismo y Construcciones define "norma técnica oficial" como aquella elaborada por el Instituto Nacional de Normalización y aprobada por decreto supremo. Por su parte, la sección 3.4.3 de la NCh1-2011 "Normas Chilenas NCh - Definiciones y procedimiento para su estudio y mantención", indica que "norma chilena oficial" es aquella norma chilena a la cual la autoridad competente le confiere, voluntariamente, la condición de oficial de la República de Chile.

${ }^{71}$ La Contraloría General de la República ha reconocido el carácter vinculante de las normas chilenas cuando estas han sido declaradas oficiales mediante decreto supremo publicado en el Diario Oficial (véase dictamen 26.430, de 30.04.2013).
} 
Polít. crim. Vol. 13, № 25 (Julio 2018) Art. 11, pp. 387-444.

[http://www.politicacriminal.cl/Vol_13/n_25/Vol13N25A11.pdf]

"elementos de uso médico"72 se sujetarán a las especificaciones técnicas fijadas por las normas oficiales chilenas del Instituto Nacional de Normalización, aprobadas por el Ministerio de Salud.

La incorporación administrativa no presenta los problemas de constitucionalidad característicos de la remisión dinámica, puesto que el Ejecutivo no pierde el control del contenido de la regla extrajurídica. Si bien es una instancia normativa privada la que elabora la reglamentación técnica, esta solo adquiere fuerza vinculante a través de un acto administrativo expreso, que aprueba el texto de la reglamentación y lo califica de "oficial".

\subsubsection{Resultado provisional}

Los programas no estatales de minimización de riesgos para la vida o salud individual (solo) tienen carácter vinculante en la medida que una norma jurídica los incorpore o permita incorporarlos al Derecho objetivo, y siempre que la respectiva técnica de remisión satisfaga los principios constitucionales del Estado de Derecho y democrático. Bajo estas condiciones, las reglamentaciones privadas de disminución de peligros alcanzan trascendencia jurídica como elementos que concretan la norma de remisión. La conducta del sujeto que se ajusta a tales reglamentaciones representa un comportamiento permitido por el Derecho; en consecuencia, el riesgo que pueda generar siempre tendrá el carácter de tolerado (en el sentido de los delitos culposos de resultado de los arts. 490 y 491 del Código Penal). Por el contrario, la conducta que se desvía de esas reglas creará normalmente riesgos desaprobados, al quedar esta ya fuera del ámbito de actuación jurídicamente garantizado.

Como los casos en que los programas no estatales de disminución de peligros logran un carácter vinculante son excepcionales, de su acatamiento no cabe deducir sin más el carácter tolerado (por el Derecho) del respectivo peligro creado, ni de su inobservancia la naturaleza desaprobada (jurídicamente) del mismo. Por eso, para que las reglamentaciones extrajurídicas no incorporadas al Derecho objetivo sirvan de pauta para distinguir entre riesgos tolerados y desaprobados -en el sentido de los delitos culposos de los arts. 490 y 491 del Código Penal- es indispensable que concurran determinados presupuestos materiales, los que serán examinados en detalle en la sección siguiente.

\section{La función de las reglas extrajurídicas en el juicio de peligrosidad de la conducta típica. Las reglamentaciones extrajurídicas como expresión de una adecuada ponderación de intereses}

\subsection{Las reglas extrajurídicas como corporeización de la experiencia}

Sin perjuicio de que las reglas extrajurídicas no fijan de un modo vinculante el límite entre los riesgos permitidos y aquellos desaprobados, existe acuerdo en que ellas plasman un saber

\footnotetext{
${ }^{72}$ Según el art. 111 del Código Sanitario, los elementos de uso médico consisten en instrumentos, aparatos, dispositivos y otros artículos o elementos destinados al diagnóstico, prevención y tratamiento de enfermedades de seres humanos, así como al reemplazo o modificación de sus anatomías y que no correspondan a las substancias descritas en los artículos 95, inciso primero, 102 y 106, todos del Código Sanitario.
} 
CONTRERAS, Lautaro. "Reglas extrajurídicas y creaciones de riesgos toleradas o desaprobadas en los delitos culposos de homicidio y lesiones".

empírico aplicado ${ }^{73}$. Tales reglas son una manifestación de la experiencia general de que en determinadas situaciones -a través de ciertas formas de comportamiento-, es probable que se desencadenen cursos lesivos para bienes jurídicos ${ }^{74}$. A modo de ejemplo: cuando un médico no consulta al paciente si está en ayunas antes de someterlo a una anestesia general, es posible que el enfermo aspire involuntariamente el contenido gástrico de su estómago durante la cirugía, generándose graves peligros para la vida; por eso existen reglas del arte que buscan eliminar esos riesgos.

Bajo el presupuesto de que las circunstancias de la conducta respectiva coincidan con la constelación fáctica abarcada por la regla extrajurídica, es decir, concurra una identidad de riesgo ${ }^{75}$ la regla puede facilitar al individuo actuante, y también al aplicador del Derecho, la respuesta a la pregunta relativa a los cursos causales posibles o probables que desencadenará el comportamiento ${ }^{76}$. De esta manera, los programas de reducción de riesgos no estatales permiten fundar el juicio de previsibilidad, indispensable para afirmar la tipicidad de la conducta negligente ${ }^{77}$. Porque una norma de conducta que -en interés de la protección de bienes jurídicos- pretenda producir algún efecto en la actuación del sujeto, resulta inútil y, en consecuencia, no puede justificarse en modo alguno, si el destinatario potencial de la norma, a pesar de su disposición a cumplirla, no tiene ninguna posibilidad de desplegar una actuación que domine el riesgo ${ }^{78}$. Por eso, una norma de conducta solo puede estar referida a peligros evitables ${ }^{79}$. Condición básica para la evitabilidad de la realización típica es justamente su previsibilidad; un resultado, que escape de lo previsible, no puede tenerse en cuenta en la reflexión que ha de llevar a cabo el sujeto acerca de cómo ajustar su conducta para evitar consecuencias lesivas ${ }^{80}$.

\subsection{El presupuesto para que una regla extrajurídica fije el deber de conducta en los delitos culposos de resultado: la expresión de una adecuada ponderación de intereses}

\footnotetext{
${ }^{73}$ Así FEIJÓO, Resultado lesivo, cit. nota $\mathrm{n}^{\mathrm{o}}$ 17, p. 311; FRISCH, Tatbestandsmäßiges Verhalten, cit. nota $\mathrm{n}^{\mathrm{o}}$ 10, p. 103; de acuerdo con él BRÄUTIGAM-ERNST, Stephanie, Die Bedeutung von Verwaltungsvorschriften für das Strafrecht - Dargestellt am Beispiel der $\$ \S 325,325$ a StGB und der Technischen Anleitungen des Immissionsschutzrechts, Baden-Baden: Nomos, 2010, p. 318; véase también JAKOBS, Strafrecht, cit. nota ${ }^{\circ}$ 2, Sección 7, número marginal 44; KÜHL, Strafrecht, cit. nota $n^{\circ} 14, \S 17$, número marginal 23; STRATENWERTH, Günter, Derecho penal Parte General I - El hecho punible, 4a edición, Buenos Aires: Hammurabi, 2005, § 15, número marginal 21.

${ }^{74}$ En este sentido (aunque respecto de los programas de reducción de riesgos estatales) PUPPE, Ingeborg, “Vorbemerkungen zu $§ \S 13$ ff”, en: KINDHÄUSER, Urs et al (Editores), Nomos Kommentar, Strafgesetzbuch, Tomo 1, 5 edición, Baden-Baden: Nomos, 2017, número marginal 156. En palabras de Schäfer: "En caso de inobservancia de tales reglas [extrajurídicas] es previsible según la experiencia general el acaecimiento de una lesión al bien jurídico" (SCHÄFER, Das Recht, cit. nota n 44, p. 157).

${ }^{75}$ Más detalles sobre la importancia de la identidad de riesgo como condición para que las reglas extrajurídicas permitan fijar el cuidado debido en infra 5.1.2.

${ }^{76}$ Véase SATZGER, Die Europäisierung, cit. nota ${ }^{\circ} 24$, p. 609 y s.

${ }^{77}$ Así FRISCH, Tatbestandsmäßiges Verhalten, cit. nota $\mathrm{n}^{\circ} 10$, p. 103.

${ }^{78}$ En este sentido FREUND, Georg, Erfolgsdelikt und Unterlassen, Köln: Heymann, 1992, p. 36 y s.

${ }^{79}$ FREUND, Erfolgsdelikt, cit. nota $\mathrm{n}^{\mathbf{0}}$ 78, p. 36; cfr. también REUS, Katharina, Das Recht in der Risikogesellschaft - Der Beitrag des Strafrechts zum Schutz vor modernen Produktgefahren, Berlin: Duncker \& Humblot, 2010, p. 85 y s.

${ }^{80}$ Véase STERNBERG-LIEBEN, Detlev; SCHUSTER, Frank, "StGB $§ 15$ Vorsätzliches und fahrlässiges Handeln”, en: Schönke/Schröder Strafgesetzbuch Kommentar, 29ª edición, München: C. H. Beck, 2014, número marginal 125; cfr. también POLITOFF, Sergio et al, Lecciones de Derecho penal chileno Parte General, $2^{\mathrm{a}}$ edición, Santiago de Chile: Editorial Jurídica de Chile, 2008, p. 285.
} 
Polít. crim. Vol. 13, № 25 (Julio 2018) Art. 11, pp. 387-444.

[http://www.politicacriminal.cl/Vol_13/n_25/Vol13N25A11.pdf]

3.2.1. La reglamentación extrajurídica no puede imponer gravámenes excesivos al ejercicio de la libertad de acción

Si de acuerdo con lo recién expuesto, los programas no estatales de reducción de riesgos permiten fundar el juicio de previsibilidad, los cursos lesivos que se desencadenan como consecuencia de la inobservancia de tales programas representan cursos cuyo acaecimiento era probable conforme a la experiencia de vida general. En otras palabras: las conductas que se desvían de lo recomendado en tales programas son conductas que normalmente tienen la idoneidad para dañar al bien jurídico ${ }^{81}$. Con todo, la previsibilidad del acaecimiento del resultado -basada en el contenido de las respectivas reglamentaciones extrajurídicas-, no permite por sí misma afirmar la tipicidad de la conducta en el sentido de los delitos culposos de los arts. 490 y 491 del Código Penal; tal previsibilidad significa -solamente- que la respectiva conducta es peligrosa, es decir, que en caso de ejecutarse existe la posibilidad cierta o la probabilidad de producción de resultados ${ }^{82}$. Como casi todas las actividades de nuestra vida en comunidad pueden crear de uno u otro modo determinados riesgos, el elemento determinante para establecer la contrariedad a deber de la conducta no puede consistir en la previsibilidad del acaecimiento del resultado, sino en si la posibilidad de daño vinculada con la actuación ha de ser evitada conforme a valoraciones jurídicas ${ }^{83}$. Es decir, lo decisivo para la desaprobación de una conducta no es el aspecto fáctico de la previsibilidad, sino el componente normativo del deber jurídico ${ }^{84}$, que ha de fijarse de acuerdo con una ponderación de bienes e intereses. Luego, para que la conducta que se desvía de la regla extrajurídica genere un riesgo jurídicamente desaprobado, no basta con que se genere un peligro previsible de acuerdo con la experiencia acumulada en el respectivo sector técnico o científico; es necesario, además, que el sujeto actuante haya infringido aquello que podía exigírsele para evitar el riesgo, de acuerdo con una adecuada ponderación de bienes e

\footnotetext{
${ }^{81}$ Así FRISCH, Tatbestandsmäßiges Verhalten, cit. nota no 10, p. 103 y s.

${ }^{82}$ FRISCH, Tatbestandsmäßiges Verhalten, cit. nota $\mathrm{n}^{\circ} 10$, p. 104. Sobre el concepto de peligro (y riesgo) en detalle, por ejemplo, KINDHÄUSER, Urs, Gefährdung als Straftat-Rechtstheoretische Untersuchungen zur Dogmatik der abstrakten und konkreten Gefährdungsdelikte, Frankfurt am Main: Vittorio Klostermann, 1989, pp. 201 y ss.; PERRON, Walter, "StGB § 34 Rechtfertigender Notstand”, en: Schönke/Schröder Strafgesetzbuch Kommentar, 29a edición, München: C. H. Beck, 2014, números marginales 12 y ss.; REUS, Das Recht in der Risikogesellschaft, cit. nota $\mathrm{n}^{\circ} 79$, pp. 24 y ss.; SCHMIDHÄUSER, Eberhard, Strafrecht Allgemeiner Teil Lehrbuch, 2a edición, Tübingen: Mohr Siebeck, 1975, 8/32 y s.; WELZEL, Derecho penal, cit. nota $\mathrm{n}^{\circ} 2$, p. 55. ${ }^{83}$ Véase, en este sentido, FREUND, Georg, "Die Definitionen von Vorsatz und Fahrlässigkeit - Zur Funktion gesetzlicher Begriffe und ihrer Definition bei der Rechtskonkretisierung”, en HETTINGER, Michael et al (Editores), Festschrift für Wilfried Küper zum 70. Geburtstag, Heidelberg: Müller, 2007, pp. 63-82, p. 76; FREUND, Strafrecht, cit. nota n ${ }^{\circ}$ 9, § 5, número marginal 44; KÜHL, Strafrecht, cit. nota n ${ }^{\circ} 14$, $§ 17$, número marginal 17; RUDOLPHI, Hans-Joachim; JÄGER, Christian, "Vor $\S 1$ ", en: WOLTER, Jürgen (Editor), Systematischer Kommentar zum Strafgesetzbuch, Tomo I, 8 a edición, actualizada a diciembre de 2014, Neuwied: Carl Heymanns, 2015, número marginal 94.

${ }^{84}$ Así HERZBERG, Die Verantwortung, cit. nota $\mathrm{n}^{\circ}$ 24, p. 165; KUHLEN, Lothar, Fragen einer strafrechtlichen Produkthaftung, Heidelberg: Müller, 1989, p. 94. Con esto no se quiere decir que para la determinación de la contrariedad a deber tenga que renunciarse por completo al elemento de la previsibilidad (= al carácter peligroso de la conducta desde una perspectiva ex ante); por el contrario, la previsibilidad permite establecer la probabilidad del concreto suceso causante del resultado, fijando de este modo los límites externos de aquello que puede ser calificado como una creación de riesgo jurídicamente desaprobado (cfr. RUDOLPHI; JÄGER, "Vor $\S 1 ”$, cit. nota nº 83, número marginal 94).
} 
CONTRERAS, Lautaro. "Reglas extrajurídicas y creaciones de riesgos toleradas o desaprobadas en los delitos culposos de homicidio y lesiones".

intereses ${ }^{85}$. Para ello, resulta indispensable que la correspondiente regulación extrajurídica no imponga (con la finalidad de conservar bienes ajenos) un gravamen excesivo al ejercicio de la libertad de acción del destinatario de la regla y, eventualmente, al ejercicio de la libertad del sujeto cuyos bienes se protegen a través de la reglamentación. Sobre esto volveremos con detalle más adelante (infra 3.3.).

3.2.2. La reglamentación extrajurídica no puede proteger de un modo insuficiente los bienes jurídicos vida y salud individual

En un sentido contrario a lo recién expuesto, es posible que las reglas extrajurídicas no establezcan lo óptimo de aquello que -de acuerdo con la experiencia acumulada en el respectivo sector- ha de hacerse u omitirse para controlar ciertos peligros. Esto puede obedecer a distintas razones. Así, no puede descartarse que la reglamentación extrajurídica se haya mostrado desde su dictación como insuficiente para el resguardo de la vida y salud individual, ya sea por una incorrecta evaluación de la eficacia de la reglamentación, o porque en forma intencionada se privilegiaron desmedidamente los intereses en la libertad de acción del destinatario de la regla (por sobre los intereses de terceros en la mantención de sus bienes jurídicos) ${ }^{86}$. Pero la razón más frecuente que puede explicar que, teniendo a la vista la experiencia acumulada, una determinada reglamentación extrajurídica no evite de manera eficaz un resultado lesivo es su obsolescencia. El permanente desarrollo científico y tecnológico hace que los mecanismos de reducción de peligros se perfeccionen continuamente; en consecuencia, reglas extrajurídicas que fijan en un determinado momento el estado de la ciencia y de la técnica para una efectiva mantención de bienes se transforman, tarde o temprano, en inadecuadas en atención a la evolución de las circunstancias ${ }^{87}$. Cabe preguntarse cuándo, exactamente, una regla extrajurídica ha de calificarse de obsoleta; la obsolescencia se verificará desde el momento en que la correspondiente reglamentación haya perdido su reconocimiento general como mecanismo de reducción de peligros dentro del círculo de expertos, es decir, cuando ya no exprese el consenso existente entre los especialistas sobre aquello que aparece como idóneo para la mantención de bienes jurídicos ${ }^{88}$. No basta con que una opinión minoritaria - aun cuando goce de cierto prestigio- estime que la regla extrajurídica se ha visto superada por los avances de la respectiva especialidad; es necesario que esa opinión termine imponiéndose entre los expertos ${ }^{89}$. Desde el momento en que la regla ya no refleje la postura mayoritaria de los integrantes del respectivo sector sobre

\footnotetext{
${ }^{85}$ Así FRISCH, Tatbestandsmäßiges Verhalten, cit. nota $\mathrm{n}^{\circ} 10$, p. 104; coincidente BRÄUTIGAM-ERNST, Die Bedeutung von Verwaltungsvorschriften, cit. nota $\mathrm{n}^{\mathrm{o}} 73$, p. 318.

${ }^{86}$ Con todo, en la medida que en la instancia no estatal donde tuvo su origen la reglamentación extrajurídica se hayan visto representados los distintos intereses afectados por la regulación y se haya contado con una asesoría técnica o científica idónea, se tratará de una situación poco frecuente (sobre esto véase infra 4.1.).

${ }^{87}$ Así MÜLLER-FOELL, Die Bedeutung, cit. nota no 39, p. 108.

${ }^{88}$ Cfr. MÜLLER-FOELL, Die Bedeutung, cit. nota no 39, p. 109 (el destacado es nuestro). La pérdida de consenso entre los especialistas del sector sobre la eficacia de una regla extrajurídica como mecanismo para la conservación de bienes puede materializarse de diversas formas (véase en lo que sigue MÜLLER-FOELL, Die Bedeutung, cit. nota $\mathrm{n}^{\text {o } 39}$, p. 109); por ejemplo, a través de la dictación de un nuevo programa no estatal de reducción peligros, que sea reconocido por la generalidad como válido para la protección de bienes jurídicos, o a través del inicio de un proceso de revisión o corrección de la normativa extrajurídica por parte de una instancia no estatal (tal procedimiento ya demuestra que la regulación ha presentado problemas en su aplicación práctica como medio para una adecuada protección de bienes, decayendo entonces el acuerdo general sobre su eficacia). ${ }^{89}$ Así MÜLLER-FOELL, Die Bedeutung, cit. nota no 39, p. 109 y s.
} 
Polít. crim. Vol. 13, № 25 (Julio 2018) Art. 11, pp. 387-444.

[http://www.politicacriminal.cl/Vol_13/n_25/Vol13N25A11.pdf]

aquello que resulta eficaz para la eliminación o reducción de peligros, y el nuevo mecanismo pueda implementarse sin un costo excesivo para el ejercicio de la libertad de acción, la conducta que observe la reglamentación obsoleta deberá verse como la creación de un riesgo jurídicamente desaprobado ${ }^{90}$. En este caso, la regla extrajurídica tampoco será expresión de una adecuada ponderación de intereses, pero no ya -a diferencia de lo que se refirió anteriormente- por una eventual carga excesiva sobre el ejercicio de la libertad del destinatario de la regla, sino por una protección indebida de la vida y salud individual.

\subsubsection{Sobre los intereses que han de ser ponderados}

De lo dicho hasta ahora es posible sostener que una reglamentación extrajurídica permitirá fijar la medida del cuidado debido y, con ello, el límite entre los riesgos tolerados y los desaprobados, cuando sea expresión de una adecuada ponderación de bienes e intereses (criterio de adecuación o de proporcionalidad en sentido estricto) ${ }^{91}$. Aquí habrá de considerarse no solo el interés en la mantención de bienes jurídicos que persiguen tales reglamentaciones, así como el interés en la realización de la conducta de los sujetos que han de acatarlas, sino también el interés en el ejercicio de la libertad de acción de las propias personas cuyos bienes jurídicos son protegidos a través de las reglas ${ }^{92}$. Este último valor también habrá de tenerse en cuenta, ya que puede darse el caso de un programa de reducción de riesgos no estatal que establezca medidas extremadamente gravosas en aras del control de ciertos peligros, lo que podría terminar coartando severamente la libertad de los propios "sujetos protegidos"93. Debido a las dificultades técnicas de implementación o a los altos

\footnotetext{
${ }^{90} \mathrm{Al}$ respecto en detalle infra 6.2.1.

${ }^{91}$ Cfr. FRISCH, Tatbestandsmäßiges Verhalten, cit. nota $\mathrm{n}^{\circ} 10$, pp. 104 y ss. En favor de una ponderación de intereses para fijar las normas de conducta cuyo quebrantamiento es presupuesto para la aplicación de los delitos culposos de resultado DONATSCH, Andreas, Sorgfaltsbemessung und Erfolg beim Fahrlässigkeitsdelikt, Zürich: Schulthess Polygraphischer Verlag, 1987, pp. 131, 138 y s., 178 y ss.; KUHLEN, Fragen, cit. nota ${ }^{\circ}$ 84, pp. 93 y ss.; SCHÜNEMANN, Bernd, "Moderne Tendenzen in der Dogmatik der Fahrlässigkeits- und Gefährdungsdelikte”, JA (1975), pp. 575-584, pp. 575 y ss.; VEIT, Die Rezeption, cit. nota no 42, pp. 194 y ss.; VOGEL, “§ 15 Vorsätzliches und fahrlässiges Handeln”, cit. nota n ${ }^{\circ} 15$, número marginal 216 (quien aboga por una ponderación de todos los intereses jurídicamente relevantes -derechos, bienes jurídicos, intereses protegidos o al menos reconocidos jurídicamente-, considerando las circunstancias del caso concreto). En el ámbito del Derecho civil a favor de la ponderación de intereses como criterio para fijar el estándar de cuidado, por ejemplo, KÖTZ, Hein, Deliktsrecht, 6ª edición, Neuwied: Luchterhand, 1994, números marginales 109 y ss.; MÜNZBERG, Wolfgang, Verhalten und Erfolg als Grundlagen der Rechtswidrigkeit und Haftung, Frankfurt am Main: Klostermann, 1966, pp. 265 y ss.

92 Otros intereses que pueden ser tenidos en cuenta en el juicio de ponderación serían, por ejemplo, intereses macroeconómicos, intereses en la mantención de puestos de trabajo, intereses en el desarrollo de alternativas técnicas, etc. (véase, al respecto, GROßE VORHOLT, Behördliche Stellungnahmen, cit. nota n 24 , pp. 87 y ss.). Estos intereses podrían efectivamente verse menoscabados a través de la imposición de normas de conducta que establecieran medidas de cuidado excesivas. Sin embargo, cuando se trata de la legitimación de deberes que sirven a la protección de bienes jurídicos elementales (como son la vida y salud individual), es dudoso si y sobre todo cómo- semejantes intereses de carácter económico han de ser considerados en el juicio de ponderación (en este sentido CONTRERAS, Lautaro, Normative Kriterien zur Bestimmung der Sorgfaltspfichten des Produzenten, Berlin: Duncker \& Humblot, 2012, p. 210 [nota 100]).

${ }^{93}$ Piénsese en una reglamentación extrajurídica que prohibiera a cirujanos sin determinados años de experiencia llevar a cabo operaciones relativamente sencillas, limitándose de este modo el número de intervenciones a las que podrían acceder los pacientes; o en reglas que establecieran medidas de seguridad antisísmicas que evitaran incluso - en caso de fuertes terremotos-daños no estructurales a los edificios, elevando de un modo desmedido el precio de las viviendas.
} 
CONTRERAS, Lautaro. "Reglas extrajurídicas y creaciones de riesgos toleradas o desaprobadas en los delitos culposos de homicidio y lesiones".

costos (reflejados necesariamente en los precios) que traerían aparejadas medidas de reducción de riesgos semejantes, los "sujetos protegidos" se verían imposibilitados de acceder a bienes, actividades o servicios que desean, perdiendo tales medidas toda justificación. No puede perderse de vista que el trasfondo, y el presupuesto de toda prohibición típica de determinadas conductas de terceros, es el interés de los eventualmente afectados en sus bienes por estas conductas, en su no realización; si falta tal interés, entonces está ausente también el fundamento legitimador de la restricción a la libertad de actuación de los terceros ${ }^{94}$.

\subsection{Criterios que deben guiar la ponderación de intereses}

Como se señaló, un programa de reducción de riesgos no estatal será expresión de una adecuada ponderación de intereses cuando la afectación o limitación de la libertad de los sujetos que han de observarlo, así como de la libertad de los titulares de la vida y salud individual que tal programa pretende resguardar, "no pese" más que la necesidad de protección de bienes jurídicos existente en el caso concreto ${ }^{95}$. De este modo, el juicio de adecuación de una reglamentación extrajurídica como mecanismo de protección de la vida y salud individual podrá afirmarse si -a través de una ponderación de todos los intereses contrapuestos- quede un "saldo" a favor de la necesidad de prohibir la correspondiente creación de riesgos ${ }^{96}$.

Se ha señalado que la ponderación de intereses como método de argumentación jurídica tendría un carácter meramente formal. Se trataría de un mecanismo que no ofrece ningún criterio para valorar y sopesar los intereses que han de examinarse ${ }^{97}$. Una ponderación de bienes e intereses que no se oriente a través de principios o reglas, podría permitir eventualmente en un caso concreto la adopción de una decisión justa, pero no está en condiciones de dirigir normativamente la fijación del Derecho ${ }^{98}$. Incluso los partidarios de la ponderación de intereses como procedimiento de concreción de los deberes de cuidado reconocen que -a falta de un criterio que guíe de modo vinculante la ponderación-, se corre el riesgo de que el respectivo juez acabe pronunciando un mero acto de voluntad ${ }^{99}$, que escape a cualquier tipo de control jurisdiccional ulterior. En atención a los riesgos que esto supone

\footnotetext{
${ }^{94}$ FRISCH, Wolfgang, "Selbstgefährdung im Strafrecht - Grundlinien einer opferorientierten Lehre vom tatbestandsmäßiges Verhalten”, NStZ (1992), pp. 1-7, 62-67, p. 6; véase también FRISCH, Tatbestandsmäßiges Verhalten, cit. nota $\mathrm{n}^{\circ} 10$, p. 76.

${ }^{95}$ Cfr. DOMEIER, Danja, Gesundheitsschutz und Lebensmittelstrafrecht, Frankfurt am Main: Peter Lang, 1999, pp. 99 y 136.

${ }^{96}$ Cfr. FREUND, Strafrecht, cit. nota n ${ }^{\circ} 9, \S 1$, número marginal 20. Solo así la reglamentación será expresión de una valoración jurídica justa y, en consecuencia, podrá ser aceptada por sus destinatarios como pauta de conducta, lo que resulta indispensable para su eficacia fáctica (en este sentido, expresamente, FREUND, Georg, "Richtiges Entscheiden - am Beispiel der Verhaltensbewertung aus der Perspektive des Betroffenen, insbesondere im Strafrecht Zugleich ein Beitrag zur Relativität objektiver Daten", GA (1991), pp. 387-410, p. 396).

${ }^{97}$ Así NELL, Ernst, Wahrscheinlichkeitsurteile in juristischen Entscheidungen, Berlin: Duncker \& Humblot, 1983, p. 137.

${ }^{98}$ Cfr. BVerfGE 66, 116, 138.

${ }^{99}$ SCHÜNEMANN, "Moderne Tendenzen”, cit. nota n 91, p. 577.
} 
Polít. crim. Vol. 13, № 25 (Julio 2018) Art. 11, pp. 387-444.

[http://www.politicacriminal.cl/Vol_13/n_25/Vol13N25A11.pdf]

para la seguridad jurídica, es indispensable desarrollar pautas normativas que dirijan la ponderación y que permitan guiar la labor que enfrenta el aplicador del Derecho ${ }^{100}$.

\subsubsection{La capacidad de aceptación recíproca como criterio para la ponderación ${ }^{101}$}

Es necesario tener presente que el juicio de adecuación al que todo deber de conducta ha de someterse exige situar en una relación mutuamente aceptable la libertad del destinatario del deber, por una parte, con la libertad y los bienes jurídicos del beneficiado con el control de riesgos que el deber persigue, por otra ${ }^{102}$. Por eso, una idea básica que permite orientar de manera justa y razonable el proceso de ponderación de intereses en el marco de las reglas extrajurídicas, lo constituye el principio de capacidad de aceptación recíproca de la solución que resulte de tal proceso. Luego, para determinar si una regla extrajurídica es adecuada o no hay que preguntarse si el resultado de la ponderación reflejada en ella sería aprobado por los respectivos interesados, independientemente de si ocuparan la posición de destinatarios de la regla o de beneficiados por las medidas de control de riesgos previstos en ella (= titulares de los bienes jurídicos) $)^{103}$.

Conforme a lo expuesto, un programa no estatal de reducción de riesgos contendrá una adecuada ponderación de intereses cuando una persona sensata, que no conociera su posición en la sociedad como eventual destinatario del programa o como titular de los bienes jurídicos protegidos por este, se mostraría de acuerdo con el contenido de la correspondiente regulación. Ahora bien, una persona razonable aceptaría la regulación cuando esta cumpliera dos condiciones.

En primer lugar, cuando la reglamentación extrajurídica disminuyera el respectivo riesgo hasta un umbral tal que una persona interesada en la mantención de sus bienes jurídicos no dejaría de exponerse al peligro residual que subsiste pese a la observancia de la reglamentación ${ }^{104}$. A modo de ejemplo: una regla extrajurídica que detalla los controles a los

\footnotetext{
${ }^{100}$ En este sentido SCHÜNEMANN, “Moderne Tendenzen”, cit. nota no 91, p. 577.

${ }^{101}$ El desarrollo de estas ideas para el ámbito específico de las reglas técnicas que rigen en materia de responsabilidad por el producto se encuentra en CONTRERAS, Normative Kriterien, cit. nota $\mathrm{n}^{\circ} 92$, pp. 212 y ss.

${ }^{102}$ De eso se trata siempre el problema de fijar los contornos de los deberes de conducta: cómo la libertad de los unos se puede colocar en una relación adecuada con la libertad y los bienes de los demás (FRISCH, Wolfgang, "Zum gegenwärtigen Stand der Diskussion und zur Problematik der objektiven Zurechnungslehre", GA (2003), pp. 719-743, p. 734; MURMANN, Uwe, "Zur Berücksichtigung besonderer Kenntnisse”, cit. nota no 21, p. 129).

${ }^{103}$ Acerca de la capacidad de aceptación recíproca como punto de partida de la ponderación véase SIECKMANN, Jan-Reinard, “Abwägung von Rechten”, ARSP 81 (1995), pp. 164-184, p. 181. Sobre la capacidad de aceptación recíproca de una solución como método de concreción del Derecho véase FRISCH, Wolfgang, "Wesenszüge rechtswissenschaftlichen Arbeitens - am Beispiel und aus der Sicht des Strafrechts (Kommentar)", en: ENGEL, Christoph; SCHÖN, Wolfgang (Editores), Das Proprium der Rechtswissenschaft, Tübingen: Mohr Siebeck, 2007, pp. 156-184, p. 177; HABERMAS, Jürgen, Faktizität und Geltung - Beiträge zur Diskurstheorie des Rechts und des demokratischen Rechtsstaats, $2^{\text {a }}$ edición, Frankfurt am Main: Suhrkamp, 1992, pp. 138 y ss.; RAWLS, John, Eine Theorie der Gerechtigkeit, Frankfurt am Main: Suhrkamp, 1975, pp. 81 y ss., $85,158,159$ y ss.

${ }^{104}$ La idea de que sobre el individuo pesa la prohibición de crear aquellos riesgos al que una persona sensata no se expondría es destacada por FRISCH, Tatbestandsmäßiges Verhalten, cit. nota n 10, pp. 128 y s., 138 y s. Véase también FRISCH, Estudios sobre imputación, cit. nota nº 17, pp. 65 y 72.
} 
CONTRERAS, Lautaro. "Reglas extrajurídicas y creaciones de riesgos toleradas o desaprobadas en los delitos culposos de homicidio y lesiones".

que ha de someterse habitualmente un tipo de autobús reduce (en caso de cumplirse) el riesgo de accidentes hasta un nivel tal que permite a un pasajero prudente tomar la decisión de utilizar la máquina como medio de transporte. También el destinatario de una norma semejante $-\mathrm{v}$. gr. el jefe de mantención de la respectiva empresa de transportes-, que asumiera el rol de pasajero del propio bus cuya seguridad tiene a su cargo, se mostraría de acuerdo con esta condición que ha de satisfacer el juicio de adecuación. El cumplimiento de esta condición -"la reglamentación ha de reducir el riesgo hasta un umbral tal que un sujeto interesado en la protección de sus bienes no dejaría de exponerse al peligro residual subsistente en caso de cumplimiento de la regla" - garantiza que en el juicio de ponderación se consideren suficientemente los intereses del titular de los bienes jurídicos protegidos a través de la reglamentación extrajurídica.

En segundo lugar, un individuo razonable aceptaría el contenido de un programa no estatal de reducción de riesgos siempre y cuando su observancia no despojara al bien, actividad o servicio al que quiere acceder de su función natural, ni tampoco aumentara su costo o disminuyera su disponibilidad hasta un punto tal que las personas terminaran privándose de él. Los individuos no están interesados en medidas de reducción de riesgos que anulen la función característica que presta un objeto o actividad ${ }^{105}$. Por eso $-\mathrm{y}$ a modo ejemplar-, una regla extrajurídica no podría obligar a un fabricante de productos farmacéuticos a eliminar por completo el riesgo de incendio o quemaduras que el uso inapropiado de alcohol en gel puede provocar, puesto que entonces el efecto antiséptico del producto se anularía. Tampoco una reglamentación extrajurídica puede forzar a excluir aquellos riesgos que -si bien no son necesarios para cumplir la respectiva función que presta un bien, actividad o servicio-, son asumidos por las personas considerando otro tipo de cualidades deseadas ${ }^{106}$. Así, por ejemplo, no sería legítimo que una determinada regulación obligara a los constructores de edificios de departamentos a cerrar por completo cada balcón con ventanas de vidrio, puesto que, aunque este método disminuyera las posibilidades de caídas accidentales, los moradores serían privados de buenas condiciones de ventilación, una mayor sensación de amplitud de los espacios, etc. Pero, además, un programa no estatal de reducción de peligros no puede pretender la obtención de seguridad absoluta a cambio de costos económicos inexigibles ${ }^{107}$, o de una disminución drástica de la disponibilidad de los objetos o actividades regulados ${ }^{108}$. Ello afectaría la libertad general de actuación $-\mathrm{u}$ otra libertad específica garantizada constitucionalmente - del destinatario del correspondiente programa y, además, privaría al titular de los bienes jurídicos protegidos a través de la reglamentación, de objetos o servicios a los que desea acceder. Por ejemplo: una regulación extrajurídica no podría instruir que para eliminar los riesgos de infecciones intrahospitalarias- determinados tipos de intervenciones quirúrgicas solo se pudieran llevar a cabo a través de equipos de cirugía robótica, puesto que ello -mientras estos sistemas no se masifiquen- reduciría muy

\footnotetext{
${ }^{105}$ Sobre el papel que juegan los intereses de los titulares de los bienes jurídicos protegidos por las normas de conducta en las condiciones de legitimación que estas han de cumplir véase supra 3.2.3.

${ }^{106}$ Cfr. HÖRL, Stephanie, Die unvertretbare Gefahr im deutschen Produkthaftungsrecht, Berlin: Duncker \& Humblot, 1999, p. 127.

${ }^{107}$ Existirá una carga desmedida de costos cuando el objeto o actividad ya no pueda ser ofrecido a terceros desde un punto de vista económicamente sostenible (cfr. GROßE VORHOLT, Behördliche Stellungnahmen, cit. nota $\mathrm{n}^{\circ} 24$, p. 132).

${ }^{108}$ Cfr. LENCKNER, “Technische Normen”, cit. nota n 6, p. 500.
} 
Polít. crim. Vol. 13, No 25 (Julio 2018) Art. 11, pp. 387-444.

[http://www.politicacriminal.c1/Vol_13/n_25/Vol13N25A11.pdf]

severamente el número de cirugías a las que los pacientes podrían someterse para restablecer su salud, afectando, además, la libertad de trabajo de los médicos.

La idea de que ninguna regla extrajurídica puede despojar al bien, actividad o servicio al que se quiere acceder de su función o cualidad deseada, ni tampoco aumentar su costo a niveles inexigibles o disminuir drásticamente su disponibilidad, asegura que en el juicio de adecuación al que ha de someterse la ponderación de intereses reflejado en la regla, se consideren de un modo suficiente los intereses del "sujeto protegido" por esta, así como la libertad del destinatario de la regulación ${ }^{109}$.

3.3.2. La plausibilidad de la capacidad de aceptación recíproca del contenido de la regla extrajurídica

El juicio de adecuación al que ha de someterse el contenido de una regla extrajurídica, que exige examinar si el resultado de la ponderación reflejada en dicha regla sería aprobado por los respectivos interesados - con independencia de si ocuparan la posición de destinatarios de la regulación o de beneficiados por las medidas de control de riesgos previstos en ella-, no constituye un mecanismo aritmético que conduzca a respuestas únicas y exactas; se trata, por el contrario, de un proceso marcado por valoraciones complejas ${ }^{110}$. Esto obliga a que, por una parte, frente a la cuestión de si la regla extrajurídica reduce el riesgo hasta un umbral tal que un sujeto interesado en la protección de sus bienes no dejaría de exponerse al peligro residual subsistente, haya de admitirse cierto margen de acción al operador jurídico para entregar una respuesta correcta. También ha de reconocérsele un determinado espacio más o menos amplio de decisión para evaluar si el programa no estatal de reducción de riesgos da o no lugar a una carga desmedida de costos, o reduce o no severamente la disponibilidad de los objetos o servicios regulados. A falta de pautas normativas que permitan llegar a respuestas absolutamente precisas sobre la adecuada delimitación entre los intereses en la libertad y la mantención de bienes en una reglamentación extrajurídica, tiene que reconocerse al aplicador del Derecho -al menos en situaciones límites- cierto margen de enjuiciamiento, en el cual no existirá una única solución correcta sino distintos resultados plausibles que permitan afirmar la adecuación ${ }^{111}$. En consecuencia, una regla extrajurídica solo podrá calificarse de inadecuada cuando se sitúe con relativa claridad fuera del ámbito de decisión propio de toda ponderación de intereses relativamente complejos, privilegiando nítidamente los intereses en la libertad de acción en desmedro de los intereses en la mantención de bienes jurídicos, o viceversa ${ }^{112}$.

${ }^{109}$ Cfr. CONTRERAS, Normative Kriterien, cit. nota ${ }^{\circ} 92$, p. 213 y s.

${ }^{110}$ Cfr. LENCKNER, "Technische Normen", cit. nota $\mathrm{n}^{\circ}$ 6, p. 501; en un sentido similar referido específicamente a la ponderación de intereses FRISCH, Tatbestandsmäßiges Verhalten, cit. nota no 10, p. 109.

${ }^{111}$ Cfr. en este sentido LENCKNER, “Technische Normen”, cit. nota $n^{\circ}$ 6, p. 501; de acuerdo con él VEIT, Die Rezeption, cit. nota $\mathrm{n}^{\circ} 42$, p. 196. Este margen de enjuiciamiento que ha de reconocerse sería la consecuencia forzosa del "carácter abierto" de los tipos penales culposos (así MIKUS, Die Verhaltensnorm, cit. nota n 31 , p. 183). Sobre el "carácter abierto" o "incompleto" de los tipos imprudentes véase SERRANO, José, Teoría del delito imprudente (Doctrina general y Regulación legal), Madrid: Centro de Publicaciones de la Secretaría General Técnica del Ministerio de Justicia e Interior, 1991, pp. 157 y ss.; TORÍO, Ángel, "El deber objetivo de cuidado en los delitos culposos", ADPCP (1974), Vol. XXVII, pp. 25-59, p. 31; WELZEL, Derecho penal, cit. nota $\mathrm{n}^{\circ} 2$, p. 157 y s. Crítico respecto de la "naturaleza abierta" de los delitos imprudentes REYES, Italo, "Sobre la construcción de la exigencia de cuidado", Polit. Crim. Vol. 10 no 19 (2015), pp. 56-91, pp. 64 y ss., en: http://www.politicacriminal.cl/Vol_10/n_19/Vol10N19A3.pdf (visitado el 01.09.2017).

${ }^{112}$ Así FRISCH, Tatbestandsmäßiges Verhalten, cit. nota $\mathrm{n}^{\circ}$ 10, p. 109. 
CONTRERAS, Lautaro. "Reglas extrajurídicas y creaciones de riesgos toleradas o desaprobadas en los delitos culposos de homicidio y lesiones".

En cualquier caso, las dificultades para llegar a respuestas absolutamente precisas sobre la adecuada delimitación entre los intereses en la libertad y en la mantención de bienes plasmados en las reglamentaciones extrajurídicas-, son menos complejas de lo que parecieran a primera vista. Y es que, como se verá a continuación, es posible presumir la adecuación de tales reglamentaciones.

\section{La adecuación general de las reglas extrajurídicas}

\subsection{Argumentos en favor de la adecuación general de las reglas extrajurídicas}

Corresponde abordar la pregunta relativa a si el contenido de los programas de reducción de riesgos no estatales puede por regla general -es decir, con independencia de la valoración de un programa en particular-, estimarse como la manifestación de una adecuada ponderación de intereses. Se trata de responder las siguientes cuestiones: ¿permiten o no generalmente las reglamentaciones extrajurídicas disminuir los respectivos riesgos hasta un umbral tal que una persona razonable no dejaría de exponerse al peligro residual que puede subsistir pese a la observancia de la reglamentación? ¿Se pueden acatar generalmente las reglamentaciones extrajurídicas sin que ello tenga como consecuencia privar al respectivo bien, actividad o servicio que se regula de su utilidad o función, o sin que ello signifique un aumento excesivo de costos o una disminución severa de su disponibilidad? De la respuesta a estas preguntas va a depender que las regulaciones extrajurídicas puedan servir normalmente o no como pauta para fijar los deberes de conducta del sujeto, es decir, para establecer los límites entre los riesgos permitidos y desaprobados.

Pues bien, en la medida que las directrices extrajurídicas no contengan instrucciones de evitación de riesgos obsoletas desde el punto de vista técnico o científico, es decir, en la medida que la mayoría de los especialistas que se desempeñan en el respectivo sector no hayan dejado de considerarlas como un mecanismo eficaz de control de peligros ${ }^{113}$, tales directrices deben estimarse, por regla general, como la expresión de una adecuada ponderación de intereses ${ }^{114}$. En favor de esta afirmación cabe invocar diversas razones.

En primer lugar, es posible demostrar empíricamente que la observancia de los programas de reducción de riesgos no estatales previene en una inmensa mayoría de casos el desencadenamiento de cursos causales lesivos ${ }^{115}$. El seguimiento de las normas de seguridad antisísmicas por parte de los ingenieros que diseñan edificios en altura, la observancia de las reglas del arte médico por parte de los cirujanos vasculares, el acatamiento de las medidas de prevención de riesgos al interior de las empresas que ofrecen servicios de rafting ${ }^{116}$, etc.

\footnotetext{
${ }^{113}$ Sobre cuándo las reglas extrajurídicas han de estimarse obsoletas véase supra 3.2.2.

${ }^{114}$ FRISCH, Tatbestandsmäßiges Verhalten, cit. nota no 10, pp. 106 y ss.; FRISCH, Wolfgang, "Problemas fundamentales de la responsabilidad penal de los órganos de dirección de la empresa - Responsabilidad penal en el ámbito de la responsabilidad de la empresa y de la división del trabajo”, en: MIR, Santiago; LUZÓN, Diego (Editores), Responsabilidad penal de las empresas y sus órganos y responsabilidad por el producto, Barcelona: Bosch, 1996, pp. 99-127, p. 120; cfr. asimismo HERSCHEL, "Regeln der Technik", cit. nota n³6, p. 619.

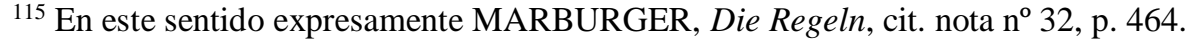

116 Véase la Nch2991.Of2006 sobre descenso en balsa o rafting.
} 
Polít. crim. Vol. 13, № 25 (Julio 2018) Art. 11, pp. 387-444.

[http://www.politicacriminal.cl/Vol_13/n_25/Vol13N25A11.pdf]

evitan en un elevadísimo número de casos la creación de riesgos para bienes jurídicos de terceros. La eficacia de tales reglas en el control de peligros se funda en la circunstancia de que en su generación intervinieron especialistas, cuya opinión hizo posible -de acuerdo con una valiosa experiencia acumulada- identificar correctamente los riesgos previsibles y ofrecer pautas de conducta eficaces para la eliminación de esos peligros o, al menos, para su reducción hasta un umbral socialmente soportable. El que en situaciones donde han de aplicarse reglas extrajurídicas se creen estados de incertidumbre para bienes jurídicos se explica -muy frecuentemente- por la inobservancia de aquellas. Luego, si las reglamentaciones no estatales previenen habitualmente que se desencadenen cursos causales lesivos, entonces tales reglamentaciones protegen sufícientemente bienes jurídicos, esto es, disminuyen los riesgos hasta un límite tal que una persona razonable no dejaría de exponerse al peligro residual que puede subsistir pese a la observancia de la reglamentación. Pero, además, de la circunstancia de que los programas de reducción de riesgos no estatales se cumplan generalmente por los sujetos cuyas conductas se pretenden regular, se puede desprender que estos no imponen medidas inexigibles y, por lo tanto, no restringen de un modo insoportable la libertad de actuación de los destinatarios de los programas, ni tampoco -consecuencialmente- la libertad de los titulares de los bienes jurídicos protegidos por estos $^{117}$.

Otro argumento en favor de la adecuación general de las reglas extrajurídicas debe hallarse en la clase de órganos encargados de la generación de dichas reglas y en las características del procedimiento de creación normativa ${ }^{118}$. Las regulaciones extrajurídicas no son el producto de una decisión arbitraria adoptada por una instancia privada cualquiera; por el contrario, son dictadas por gremios científicos o técnicos, por grupos de expertos o por instituciones que gozan de significativa autoridad, en el contexto de una sucesión rigurosamente ordenada de actos ${ }^{119}$. Así, en el proceso de estudio de las normas privadas participan frecuentemente representantes de los distintos intereses que pueden resultar afectados por la regulación, incluyendo delegados de organismos del Estado y asociaciones de consumidores. Tratándose específicamente del procedimiento de génesis de las normas chilenas en el seno del Instituto Nacional de Normalización, los acuerdos que se adopten en las diferentes etapas de estudio de las mismas han de ser consensuados $^{120}$. Pero, además, los proyectos de normas chilenas deben ser sometidos a un proceso de consulta pública, donde pueden participar todas las organizaciones y personas susceptibles de ser afectadas con la regulación en estudio ${ }^{121}$. De esta manera, las propias características del proceso de

\footnotetext{
${ }^{117}$ Véase FRISCH, Tatbestandsmäßiges Verhalten, cit. nota $\mathrm{n}^{\circ}$ 10, p. 106; de acuerdo con él MIKUS, Die Verhaltensnorm, cit. nota $\mathrm{n}^{\circ} 31$, p. 110 y s.

${ }^{118}$ En este sentido BACHMANN, Private Ordnung, cit. nota $\mathrm{n}^{\circ}$ 42, p. 341; FRISCH, Tatbestandsmäßiges Verhalten, cit. nota ${ }^{\circ}$ 10, p. 107; MARBURGER, Die Regeln, cit. nota $\mathrm{n}^{\circ} 32$, p. 464.

${ }^{119}$ Así FRISCH, Tatbestandsmäßiges Verhalten, cit. nota $\mathrm{n}^{\mathrm{o}}$ 10, p. 107; de acuerdo con él, aparentemente, MIKUS, Die Verhaltensnorm, cit. nota $\mathrm{n}^{\circ} 31$, p. 110. Sobre el procedimiento de generación de las normas chilenas véase la NCh1-2011 "Normas Chilenas NCh - Definiciones y procedimiento para su estudio y mantención".

${ }^{120}$ Véase el punto 4.9 de la NCh1-2011: "Los acuerdos que se adopten en las diferentes etapas de estudio de una norma se deben tomar por consenso". En caso de no llegarse a acuerdo unánime, es el Consejo del Instituto Nacional de Normalización quien debe adoptar la decisión sobre el contenido de la regla (véase punto 6.3.11 de la NCh1-2011).

${ }^{121}$ Punto 5.3.1. y siguientes de la NCh1-2011.
} 
CONTRERAS, Lautaro. "Reglas extrajurídicas y creaciones de riesgos toleradas o desaprobadas en los delitos culposos de homicidio y lesiones".

generación de estas reglas técnicas garantizan que en ellas se logre una adecuada consideración de los intereses en juego ${ }^{122}$.

En lo que dice relación, concretamente, con los protocolos y guías de actuación clínicas, es posible también reconocer la existencia de mecanismos en su dictación que aseguran su idoneidad como instrumentos para la conservación de los bienes jurídicos de los pacientes. Así, por ejemplo, en el caso de Alemania ${ }^{123}$, antes de la publicación de una guía por parte de la Asociación de Sociedades Médicas Científicas ${ }^{124}$ la normativa es sometida a un informe elaborado por peritos independientes, lo que permite comprobar que esta posea una alta calidad técnica $^{125}$; por otra parte, se han fijado exigencias mínimas que han de cumplirse en el proceso de dictación de una guía de actuación clínica, y se han establecido sistemas de control de calidad que permiten comprobar la idoneidad de la respectiva regulación para la protección de la salud ${ }^{126}$. Uno de los criterios que permite certificar la calidad de la guía consiste en la participación de representantes de los pacientes en su generación ${ }^{127}$.

\subsection{Posturas contrarias a la presunción de adecuación. Crítica}

En la doctrina alemana y española se pueden encontrar posiciones contrarias a la presunción de adecuación de las reglamentaciones extrajurídicas, especialmente de las reglas técnicas codificadas $^{128}$. Así, se señala que en el proceso de génesis normativa que se desarrolla al

122 Tratándose de las normas chilenas, existe otra razón para afirmar -al menos en general- la adecuación de tales reglas extrajurídicas, a saber: la remisión que hacen a ellas numerosas leyes y reglamentos para definir los deberes de cuidado que han de observarse en determinados ámbitos. Esto permite presumir que el Estado chileno considera a las regulaciones que emanan del Instituto Nacional de Normalización como programas razonables de reducción de peligros. Respecto de aquellas normas chilenas que no están incluidas en leyes o reglamentos también es posible presumir que el Estado confía en la adecuación de tales normativas privadas, puesto que parte del financiamiento que recibe el Instituto Nacional de Normalización proviene de fondos públicos (véase Documento sin título, p. 43, disponible en: http://www.inn.cl/sites/default/files/Memoria\%202007.pdf [visitado el 03/05/17]); además, se han celebrado varios convenios entre esta organización y distintos servicios públicos (véase, por ejemplo, convenio celebrado entre la Superintendencia del Medio Ambiente y el Instituto Nacional de Normalización, disponible en http://www.sma.gob.cl/index.php/noticias/notas/576-sma-convenio-inn2 [visitado el 03/05/17]). Todo lo anterior refleja una elevada confianza estatal en el trabajo de normalización desplegado

${ }^{123}$ Las reglas del arte médico emanadas de asociaciones extranjeras pueden cobrar gran relevancia en Chile para fijar el cuidado debido, puesto que en nuestro país no existen sociedades médicas con los recursos y la capacidad técnica necesarios para dictar protocolos y guías de actuación clínicas, que faciliten el diagnóstico y tratamiento de enfermedades.

${ }^{124}$ Arbeitsgemeinschaft der Wissenschaftlichen Medizinischen Fachgesellschaften (AWMF).

${ }^{125}$ Se trata de una exigencia impuesta por el "Manual de guías" (Leitlinien-Manual), elaborado en conjunto por la Asociación de Sociedades Médicas Científicas (Arbeitsgemeinschaft der Wissenschaftlichen Medizinischen Fachgesellschaften - AWMF) y el Centro Médico para la Calidad de la Medicina (Das ärztliche Zentrum für die Qualität in der Medizin - ÄZQ) en el año 2001. Al respecto véase en detalle IHLE, Judith, Ärztliche Leitlinien, Standards und Sozialrecht, Baden-Baden: Nomos, 2007, pp. 75 y ss.

${ }^{126}$ Véase IHLE, Ärztliche Leitlinien, cit. nota no 125, pp. 72 y ss.; TAUPITZ, "Verbindlichkeit", cit. nota ${ }^{\circ} 42$, p. 113.

${ }^{127} \mathrm{Cfr}$. http://www.leitlinien.de/patienten/patientenbeteiligung (visitado el 28.08.2017). Se han desarrollado, incluso, manuales de buenas prácticas internacionales que recogen recomendaciones acerca de cómo recabar la opinión de los pacientes en el marco de la elaboración de protocolos médicos (véase www.g-i-n.net/workinggroups/gin-public/toolkit, visitado el 28.08.2017).

${ }^{128}$ Véase FEIJÓO, Resultado lesivo, cit. nota n ${ }^{\circ}$ 17, p. 310 (nota al pie 922); FÜHR, Martin, "Technische Normen in demokratischer Gesellschaft”, ZUR (1993), pp. 99-102, p. 101; ROXIN, Strafrecht, cit. nota n 2 , $\$$ 
Polít. crim. Vol. 13, № 25 (Julio 2018) Art. 11, pp. 387-444.

[http://www.politicacriminal.c1/Vol_13/n_25/Vol13N25A11.pdf]

interior de las instancias no estatales encargadas de dictar reglas técnicas (v. gr. "Deutsches Institut für Normung", en Alemania; "Asociación Española de Normalización y Certificación", en España -organismos equivalentes a nuestro Instituto Nacional de Normalización-) estarían sobrerrepresentados los intereses de la industria y de las empresas, lo que dejaría en una posición muy desmejorada a los usuarios o consumidores, e impediría calificar a tales instancias como organismos neutrales ${ }^{129}$. Los gremios normativos carecerían de mecanismos de aseguramiento institucional que permitan tener en cuenta la totalidad de los valores en pugna al momento de concebir y dictar una regla técnica ${ }^{130}$. Como los intereses de las empresas siempre terminarían prevaleciendo, los propios titulares del potencial de peligro ejercerían el poder de decisión sobre el límite tolerado de los riesgos ${ }^{131}$. Para Schünemann esto resulta inadmisible: el riesgo permitido, en tanto umbral de lo penalmente relevante, solo puede ser establecido mediante el consenso de todos los afectados, y no a través de una usurpación unilateral realizada por los causantes potenciales de la perturbación al bien jurídico ${ }^{132}$.

Las posturas anteriores difícilmente pueden ser compartidas. Efectivamente, aunque se pudiera constatar que en el proceso de génesis de las reglas técnicas los intereses de las empresas están sobrerrepresentados, no tiene que suponerse que estas presionarán siempre para que se fijen los estándares de seguridad más laxos posibles ${ }^{133}$. Los intereses económicos de la industria y los intereses de conservación de bienes jurídicos de los consumidores o usuarios no han de entrar forzosamente en permanente colisión, hasta el punto de anular los primeros a los segundos. La finalidad de maximizar las ganancias puede ser muchas veces el acicate para que se establezcan exigencias de reducción de riesgos suficientemente eficaces. Porque solo aquellos productos y servicios seguros -para la vida y salud individual-, de calidad y con precios moderados van a ser adquiridos por los usuarios ${ }^{134}$. Además, como el

24, número marginal 19; SCHÜNEMANN, "Las reglas de la técnica", cit. nota $\mathrm{n}^{\circ}$ 3, pp. 319, 323 y s.; SPINDLER, Unternehmensorganisationspflichten, cit. nota $n^{\circ} 44$, p. 537.

${ }^{129}$ Cfr. SPINDLER, Unternehmensorganisationspflichten, cit. nota $\mathrm{n}^{\circ} 44, \mathrm{p}$. 537. Acerca de los motivos que podrían explicar la sobrerrepresentación de los intereses de la industria en la dictación de normativas privadas véase FÜHR, "Technische Normen", cit. nota $\mathrm{n}^{\mathrm{o}} 128$, p. 101. Debido, precisamente, a que las instancias normativas no estatales carecerían de la necesaria neutralidad, se señala en la doctrina civil alemana que las reglas técnicas dictadas por estas no podrían considerarse como "informes periciales anticipados", para efectos de probar la diligencia debida (neutralidad e independencia son notas irrenunciables de cualquier perito). La tesis según la cual las reglas técnicas constituirían "informes periciales anticipados" fue acogida, en cambio, en una importante sentencia del año 1978, dictada por el Tribunal Federal Contencioso-administrativo alemán, a propósito de la ampliación de una central térmica a carbón en la ciudad de Voerde (Niederrhein); el fallo fue publicado en $N J W 1978,1450$. En detalle sobre la posibilidad de considerar a las reglas técnicas como "informes periciales anticipados" MÜLLER-FOELL, Die Bedeutung, cit. nota ${ }^{\circ}$ 39, pp. 124 y ss.; NICKLISCH, "Technische Regelwerke", cit. n 42, pp. 841 y ss.; SPINDLER, Unternehmensorganisationspflichten, cit. nota $\mathrm{n}^{\circ}$ 44, pp. 534 y ss.; TRATZ, Die zivilprozessuale Bedeutung, cit. nota ${ }^{\circ} 32$, pp. 129 y ss.

${ }^{130}$ En este sentido JARASS, Hans, "Der rechtliche Stellenwert technischer und wissenschaftlicher Standards Probleme und Lösungen am Beispiel der Umweltstandards", NJW (1997), pp. 1225-1231, p. 1230.

${ }^{131}$ Así SCHÜNEMANN, "Las reglas de la técnica", cit. nota no 3, p. 319.

${ }^{132}$ SCHÜNEMANN, "Las reglas de la técnica", cit. nota n 3, p. 319; coincidente FEIJÓO, Resultado lesivo, cit. nota $\mathrm{n}^{\mathrm{o}} 17$, p. 310 (nota al pie 922).

${ }^{133}$ Cfr. GROßE VORHOLT, Behördliche Stellungnahmen, cit. nota no 24, p. 179.

${ }^{134}$ Así MÜLLER-FOELL, Die Bedeutung, cit. nota $n^{\circ} 39$, p. 135. A través de un exhaustivo análisis histórico de las medidas de autorregulación y de inspección técnica que -a fines del siglo XIX- la industria alemana de calderas de vapor adoptó motu proprio, esta autora ha destacado que la defensa de intereses económicos no es 
CONTRERAS, Lautaro. "Reglas extrajurídicas y creaciones de riesgos toleradas o desaprobadas en los delitos culposos de homicidio y lesiones".

cumplimiento de reglas extrajurídicas que ofrezcan suficiente protección frente a peligros es un requisito impuesto fáctica o jurídicamente para el ingreso de bienes y servicios a nuevos mercados -especialmente, internacionales $-{ }^{135}$, resulta altamente inconveniente para las empresas presionar en el proceso de génesis normativa para que se establezcan estándares precarios de cuidado; ello afectaría sobre manera el prestigio de dichas reglas como garantía de que los bienes y servicios que se ajustan a ellas no representan un riesgo intolerable para la vida y salud.

Por otra parte, aunque en los procesos de fijación de reglas extrajurídicas a través de instancias no estatales siempre existiera la posibilidad de que los puntos de vista de grupos industriales o empresariales -con una evidente capacidad de organización e influenciapredominaran, la alternativa de que las normas de cuidado se generen en el marco de procedimientos estatales no asegura en todos los casos que estas normas cristalicen una razonable ponderación de intereses. Y es que en las regulaciones del Estado en forma de leyes o reglamentos no se impone siempre la voluntad del "conjunto de la sociedad", capaz (en teoría) de plasmar apropiadamente todos los valores en pugna en la correspondiente regulación, sino en ocasiones los intereses de solo una parte de la comunidad, luego de la influencia ejercida por grupos de presión eficazmente organizados ${ }^{136}$.

Finalmente, no parece ser cierta la afirmación de que las instancias normativas no estatales carezcan por completo de un mecanismo que permita considerar apropiadamente los intereses en la mantención de bienes jurídicos. La necesaria atención de estos intereses estaría garantizada de modo suficiente a través del cumplimiento de los deberes de protección de derechos fundamentales por parte de los delegados estatales (representantes de ministerios, servicios públicos, municipalidades, etc.), que intervienen en la génesis de la normativa privada $^{137}$. En virtud de estos deberes positivos, los representantes del Estado están obligados a promover que la respectiva regulación proteja de modo bastante la vida y salud de consumidores o usuarios, oponiéndose a aquellas propuestas que descuiden de un modo intolerable tales derechos; en caso de no ser capaces de imponer sus puntos de vista en el proceso de adopción de la regla privada, dichos representantes públicos estarían obligados a

incompatible con la dictación de reglamentaciones privadas que protejan adecuadamente la vida y salud individual (MÜLLER-FOELL, Die Bedeutung, cit. nota n ${ }^{\circ}$ 39, pp. 51 y ss.).

${ }^{135}$ Se refiere al cumplimiento de las normas técnicas como exigencia fáctica impuesta para el ingreso de productos a nuevos mercados CARRILLO, Juan, El Derecho de la seguridad y de la calidad industrial, Madrid: Marcial Pons, 2000, p. 382; véase también MARBURGER, "Herstellung", cit. nota n 42, p. 102.

${ }^{136}$ BACHMANN, Private Ordnung, cit. nota $\mathrm{n}^{\circ}$ 42, p. 340. Para Nieto, la capacidad de la industria para influir en la Administración o en los órganos colegisladores cuando estos confeccionan una determinada regulación hasta llegar, incluso, a su "captura"- puede ser probablemente mayor que respecto de instancias normativas no estatales, donde las asociaciones de consumidores o usuarios siempre tienen la posibilidad de intervenir activamente en el proceso de génesis de la regla técnica (véase NIETO, Adán, "§ 5 Autorregulación, 'compliance' y justicia restaurativa”, en: ARROYO, Luis; NIETO, Adán (Directores), Autorregulación y sanciones, $2^{\text {a }}$ edición, Cizur Menor: Aranzadi, 2015, pp. 99-134, p. 106).

${ }^{137}$ Como es sabido, la función de los derechos fundamentales no se agota en asegurar a la persona determinadas esferas de libertad frente a las posibles intromisiones del Estado; además, tales derechos obligan al poder estatal a su protección y promoción activa, lo que resulta indispensable si se pretende su real vigencia (sobre el aseguramiento positivo de los derechos fundamentales véase HUFEN, Friedhelm, Staatsrecht II Grundrechte, $4^{\mathrm{a}}$ edición, München: C. H. Beck, 2014, § 5, número marginal 5). 
Polít. crim. Vol. 13, No 25 (Julio 2018) Art. 11, pp. 387-444.

[http://www.politicacriminal.c1/Vol_13/n_25/Vol13N25A11.pdf]

cumplir con sus deberes de prestaciones normativas, instando a que se dicte una regla extrapenal que sí ofrezca un resguardo suficiente ${ }^{138}$.

\subsection{Resultado provisional}

En virtud de todo lo expuesto, es posible sostener que las regulaciones extrajurídicas pueden verse, por regla general, como la manifestación de una adecuada ponderación de intereses. Precisamente porque las reglas extrajurídicas protegen suficientemente los bienes jurídicos vida y salud individual y, además, no imponen un gravamen desmedido al ejercicio de la libertad de los destinatarios de la regulación y de los titulares de los bienes jurídicos, el Estado puede prescindir en numerosos ámbitos de la dictación de normativas extrapenales detalladas, y limitarse a establecer principios generales o prohibiciones y mandatos que pueden complementarse a través del abundante material extrajurídico ya existente; por cierto, tal material permite orientar conductas en interés de la mantención de bienes jurídicos de forma equivalente a como lo hace una reglamentación estatal ${ }^{139}$. De este modo, el Estado no solo admite la posibilidad de que sean los propios círculos de interesados en determinadas actividades de carácter técnico o científico los que establezcan las correspondientes reglamentaciones, sino que se sirve de ellas como mecanismos indirectos de control de peligros, pudiendo concentrar su actividad legislativa en todas aquellas áreas para las cuales no existen catálogos normativos extrajurídicos ${ }^{140}$. Esto no debería ser objeto de reparos si se tiene en consideración que el aparato estatal frecuentemente carece de la competencia técnica para dominar a través de leyes o reglamentos riesgos de cierta complejidad, y que las normativas privadas pueden -a diferencia de las herramientas de regulación estataladaptarse con la necesaria rapidez a la cada vez más dinámica innovación técnica y científica $^{141}$.

Como los catálogos normativos extrajurídicos pueden verse, por regla general, como la expresión de una adecuada ponderación de intereses, ellos desempeñan una función equivalente a la que cumplen las reglamentaciones estatales en la delimitación entre creaciones de riesgo toleradas y desaprobadas, a pesar de no constituir normas jurídicas ${ }^{142}$. En consecuencia -y como se verá en detalle en la sección siguiente-, el cumplimiento de los catálogos normativos privados tiene que descartarse generalmente como creación de un peligro desaprobado; la inobservancia de tales catálogos, por el contrario, representará normalmente un riesgo no permitido. La equivalencia funcional entre las reglas privadas y las normativas estatales como pautas de concreción de la conducta típica podría explicar por qué algunos afirmen que el juez con competencia penal -sin perjuicio de no estar vinculado jurídicamente al contenido de las regulaciones privadas- no puede apartarse de estas sin una buena razón, debiendo indicar siempre los motivos y formular los criterios explícitos

\footnotetext{
${ }^{138}$ Cfr. GROßE VORHOLT, Behördliche Stellungnahmen, cit. nota n ${ }^{\circ}$ 24, p. 182.

139 Así FRISCH, Tatbestandsmäßiges Verhalten, cit. nota $\mathrm{n}^{\circ} 10, \mathrm{p} .108$.

${ }^{140}$ GROßE VORHOLT, Behördliche Stellungnahmen, cit. nota $\mathrm{n}^{\circ} 24$, p. 180 y s. (la cursiva es nuestra).

${ }^{141}$ Destaca la incapacidad del Estado para abordar a través de la ley determinados fenómenos técnicos o científicos en toda su complejidad, entre otros, BOSCH, Organisationsverschulden, cit. nota n ${ }^{\circ} 43$, p. 453.

${ }^{142}$ En este sentido FRISCH, Tatbestandsmäßiges Verhalten, cit. nota $\mathrm{n}^{\mathrm{o}} 10, \mathrm{p} .108$.
} 
CONTRERAS, Lautaro. "Reglas extrajurídicas y creaciones de riesgos toleradas o desaprobadas en los delitos culposos de homicidio y lesiones".

conforme a los cuales considera insuficientes tales regulaciones para el establecimiento del comportamiento típico ${ }^{143}$.

\section{Consecuencias de la observancia y de la infracción de reglas extrajurídicas adecuadas}

En los apartados anteriores hemos visto que las reglamentaciones extrajurídicas pueden servir de límite entre los riesgos desaprobados y los tolerados cuando sean expresión de una adecuada ponderación de bienes e intereses; además, se ha explicado por qué normalmente tales reglamentaciones pueden estimarse como adecuadas.

A continuación, corresponde analizar las consecuencias que tienen la observancia y la infracción de reglas extrajurídicas - que expresen una adecuada ponderación de interesespara afirmar o negar el injusto de conducta de los delitos culposos de los arts. 490 y 491 del Código Penal.

\subsection{Consecuencias de la observancia de reglas extrajurídicas adecuadas}

\subsubsection{La creación de (únicamente) riesgos tolerados}

Si el sujeto ha ajustado su conducta a la orientación prevista en una regla extrajurídica que representa una ponderación adecuada de intereses, entonces se habrá comportado de acuerdo con lo que el Derecho legítimamente le puede exigir ${ }^{144}$. El riesgo residual para la vida o salud, que eventualmente pueda subsistir pese al acatamiento de la regla, tendrá el carácter de permitido y nunca será idóneo para fundar una conducta típica en el sentido de los delitos culposos de los arts. 490 y 491 del Código Penal ${ }^{145}$. Un ordenamiento jurídico con pretensiones de coherencia se invalidaría a sí mismo si calificara un programa normativo no estatal como reflejo de un equilibrio adecuado de intereses $y$, al mismo tiempo, desaprobara la conducta que se ha ajustado a aquel.

En nada cambiará la calificación de la conducta como tolerada si se verifica un resultado lesivo que tenga su origen en la actuación conforme a la regla extrajurídica (adecuada) ${ }^{146}$. Una acción no es contraria a Derecho porque haya puesto una condición necesaria para la

${ }^{143}$ Cfr. SCHÜNEMANN, "Las reglas de la técnica", cit. nota no 3, p. 328 y s. (en el mismo sentido SCHÜRERMOHR, Erlaubte Risiken, cit. nota n ${ }^{\circ}$ 42, p. 197). Si bien Schünemann se opone a la idea de que las reglas extrajurídicas codificadas representen una ponderación adecuada de intereses -puesto que en su generación primarían los criterios economicistas defendidos por la industria-, reconoce, al mismo tiempo, que tales reglas reflejan una "racionalidad vivida y probada en la realidad de la vida diaria" y que, en consecuencia, el juez no puede apartarse sin buenas razones de lo estipulado en ellas. Pero si el autor admite que las regulaciones extrajurídicas son instrumentos cuya idoneidad para la reducción de peligros ha sido demostrada en la vida cotidiana y que, en consecuencia, el operador jurídico no puede apartarse de ellas sin formular criterios explícitos que permitan fundar una pauta de conducta alternativa, entonces está partiendo de la premisa (que él mismo critica) de que tales regulaciones sí protegen suficientemente el interés en la mantención de bienes jurídicos.

${ }^{144}$ Cfr. POLITOFF et al, Lecciones, cit. nota $n^{\circ}$ 80, p. 285: “...el médico que durante una operación realizada siguiendo las prescripciones de la ciencia médica ve con pesar el fallecimiento de su paciente, actúa lícitamente (...)".

${ }^{145}$ Cfr. FRISCH, Tatbestandsmäßiges Verhalten, cit. nota $\mathrm{n}^{\circ} 10$, p. 109; GIL, El delito imprudente, cit. nota ${ }^{\circ}$ 19, p. 271; GROßE VORHOLT, Behördliche Stellungnahmen, cit. nota $\mathrm{n}^{\circ} 24$, p. 108. En el ámbito del Derecho civil véase MARBURGER, Die Regeln, cit. nota no 32, p. 429 y s.

${ }^{146}$ En este sentido VEIT, Die Rezeption, cit. nota $n^{\circ}$ 42, p. 193. 
Polít. crim. Vol. 13, № 25 (Julio 2018) Art. 11, pp. 387-444.

[http://www.politicacriminal.c1/Vol_13/n_25/Vol13N25A11.pdf]

modificación del mundo exterior; las reglas extrajurídicas no están dirigidas a prohibir comportamientos solo porque estos tengan la aptitud de desencadenar alguna vez cursos causales lesivos (ello condenaría a la vida social a una absoluta inacción) ${ }^{147}$. Tales reglas solo persiguen la finalidad de imponer aquella medida de cuidado que pueda ser legítimamente exigible para la protección de intereses jurídicos relevantes ${ }^{148}$. Solo cuando esa medida no se observe, podrá verse una creación de riesgo desaprobada por el Derecho ${ }^{149}$.

\subsubsection{La exigencia de una "identidad de riesgo"}

Con todo, la doctrina afirma que para que la actuación que se ciñe a la norma extrajurídica solo genere un riesgo permitido, es indispensable que la norma haya querido regular precisamente la situación de peligro que se presentó en el caso concreto, esto es, que exista la necesaria "identidad de riesgo" 150 . Si se está frente a una situación "atípica", en donde existen fuentes de peligro adicionales cuya eliminación o disminución no estuvo contemplada en la reglamentación extrajurídica, entonces la actuación ajustada a esta no podrá verse ya como una creación de riesgo permitida ${ }^{151}$; solo aquel riesgo residual que subsiste en la situación de peligro contemplada expresamente en la regla extrajurídica puede ser calificado como riesgo tolerado por el Derecho ${ }^{152}$.

Un ejemplo extraído de la jurisprudencia chilena permite ilustrar la importancia que tiene considerar la "identidad de riesgo" para fijar cuáles son los peligros tolerados en cada caso: una regla técnica podría obligar a los fabricantes de pegamentos que contuvieran metanol a que se incluyera la siguiente leyenda en el etiquetado de sus productos: "Úsese en ambientes ventilados. La inhalación frecuente y prolongada de este producto genera daños irreparables a la salud". Un deber semejante solo pretende eliminar los peligros de intoxicación derivados de la aspiración de metanol; por eso, el único riesgo residual tolerado por la norma extrajurídica es aquel que subsiste no obstante la advertencia específica relativa a la

${ }^{147}$ Cfr. LENCKNER, “Technische Normen”, cit. nota n ${ }^{\circ}$ 6, p. 493.

${ }^{148}$ Cfr. LENCKNER, “Technische Normen”, cit. nota n ${ }^{\circ}$ 6, p. 493.

${ }^{149} \mathrm{Si}$, en cambio, la actuación se ajusta a la norma de conducta extrajurídica y, pese a ello, se verifica un resultado, se estará solo frente a un infortunio (y no ante un injusto). Véase LENCKNER, "Technische Normen", cit. nota $n^{\circ}$ 6, p. 493; WELZEL, Derecho penal, cit. nota ${ }^{\circ}$ 2, p. 161 . La actuación que no se ha apartado de la prohibición prevista en una regla extrajurídica solo podría fundar una responsabilidad civil por riesgo (en este sentido FREUND, Georg, "Täuschungsschutz und Lebensmittelstrafrecht Grundlagen und Perspektiven", ZLR (1994), pp. 261-304, p. 270).

${ }^{150}$ Para Lenckner, es indispensable que la norma haya "querido evitar justamente aquella situación que ha conducido al resultado típico" (Cfr. LENCKNER, "Technische Normen”, cit. nota no 6, p. 494). La expresión "identidad de riesgo" es utilizada por Satzger a propósito del efecto de las reglas extrapenales en el injusto de comportamiento (SATZGER, Die Europäisierung, cit. nota n ${ }^{\circ}$ 24, p. 611). Sobre la exigencia de "identidad de riesgo" en el ámbito del Derecho civil véase, entre otros, SCHÄFER, Das Recht, cit. nota n 44, p. 156; SPINDLER, Unternehmensorganisationspflichten, cit. nota $\mathrm{n}^{\circ} 44$, p. 542; TRATZ, Die zivilprozessuale Bedeutung, cit. nota $\mathrm{n}^{\circ} 32$, p. 94.

${ }^{151}$ Cfr. SATZGER, Die Europäisierung, cit. nota ${ }^{\circ}{ }^{24}$, p. 611. Para saber si se está frente a una situación de riesgo "típica" (prevista en la regulación extrajurídica) o "atípica" (no contemplada en la regulación) no se puede acudir a un criterio formal, sino que es necesario recurrir a las reglas tradicionales de interpretación del Derecho (KUHLEN, Fragen, cit. nota n ${ }^{\circ} 84$, p. 116).

${ }^{152}$ Cfr. FRISCH, Tatbestandsmäßiges Verhalten, cit. nota n ${ }^{\circ}$ 10, p. 92; SATZGER, Die Europäisierung, cit. nota $\mathrm{n}^{\circ} 24$, p. 611. 
CONTRERAS, Lautaro. "Reglas extrajurídicas y creaciones de riesgos toleradas o desaprobadas en los delitos culposos de homicidio y lesiones".

inhalación ${ }^{153}$. Si un fabricante no informa en el etiquetado -también- del grave peligro de muerte en caso de ingesta accidental de tal sustancia, creará un peligro jurídicamente desaprobado respecto del bien jurídico vida ${ }^{154}$.

En consideración a lo ya expuesto, se afirma que el cumplimiento de un programa normativo no estatal adecuado solo tiene un efecto indiciario para calificar la conducta como conforme a Derecho; un juicio definitivo relativo al peligro tolerado creado por el comportamiento supone la constatación de la existencia de una "identidad de riesgo"155. En el caso alemán de la fumigación del silo el Tribunal Supremo Federal destacó que, de concurrir situaciones de peligro extraordinarias para cuya eliminación o disminución una determinada regulación no prevé medida alguna, es legítimo imponer deberes de cuidado especiales que vayan más allá de la exigencia contemplada para casos normales ${ }^{156}$. El que en semejantes situaciones sean necesarias medidas de cuidado adicionales resulta evidente, puesto que los programas de prevención de riesgos no estatales carecen de una pretensión de completitud ${ }^{157}$. Ellos buscan regular múltiples casos indeterminados y, por eso, necesariamente están concebidos de un modo generalizante. Tal como ocurre con las normas extrapenales, las de naturaleza extrajurídica solo pueden establecer medidas de evitación para "casos modelo", dejándose sin regular eventos de peligro singulares ${ }^{158}$.

Sobre el sujeto actuante pesa siempre el deber jurídico de cerciorarse de que la correspondiente reglamentación no estatal efectivamente abarca el riesgo que previsiblemente puede desencadenar su conducta o de que, por el contrario, concurre una

\footnotetext{
${ }^{153}$ Un riesgo que podría subsistir pese a la advertencia relativa a la inhalación consistiría, por ejemplo, en que un consumidor utilice el producto como estupefaciente, causándose daños a su organismo.

${ }^{154}$ Cfr. caso RUC 1310032872-5, RIT 14704-2013, seguido ante el Segundo Juzgado de Garantía de Santiago, terminado por suspensión condicional del procedimiento el 28.10.2016. En este caso, un niño de ocho años ingirió una pequeña porción de pegamento que contenía metanol, muriendo intoxicado horas después. El fabricante del producto solo había advertido de los riesgos para la salud en caso de inhalación, pero no de las consecuencias mortales de una ingesta. Sobre los deberes jurídicos (especiales) de información que pesan sobre los fabricantes en favor de niños de corta edad véase FOERSTE, Ulrich, "§ 24. Verkehrspflichten im Bereich der Warenherstellung", en: FOERSTE, Ulrich; GRAF V. WESTPHALEN, Friedrich (Editores), Produkthaftungshandbuch, $3^{\mathrm{a}}$ edición, München: C. H. Beck, 2012, números marginales 300 y ss.

${ }^{155}$ Cfr. ESSER; KEUTEN, "Strafrechtliche Risiken", cit. nota no 32, p. 318; HERNÁNDEZ, "Art. $2^{\circ}$ ”, cit. nota $\mathrm{n}^{\circ} 41$, p. 112 (refiriéndose conjuntamente a las reglas extrapenales y a las extrajurídicas).

${ }^{156}$ BGHSt 37, 184, 189. Con el objeto de combatir una plaga que afectaba una cosecha de trigo, el acusado hizo aplicar, al interior de un silo, un gas que contenía fosfato de hidrógeno, sustancia extremadamente tóxica. Junto al silo se encontraba una casa donde vivía un trabajador y su familia. El insecticida ingresó desde el silo a la vivienda, matando a la familia del trabajador. Según el tribunal alemán: "Considerando las circunstancias (...) del caso concreto, especialmente frente a constelaciones de hechos peligrosas de carácter extraordinario, pueden imponerse exigencias que vayan más allá de los deberes de cuidado que hay que cumplir para evitar peligros a la vida y salud, y que están previstos en preceptos y reglas (...) Circunstancias extraordinarias que eleven el riesgo cognoscible pueden fundar deberes de cuidado que vayan más allá de la medida habitual; las exigencias pueden ser más estrictas de las que resultan de la regla impuesta para el caso promedio" (BGHSt 37, 184, 189; de acuerdo con la argumentación del tribunal ALEXANDER, Die strafrechtliche Verantwortlichkeit, cit. nota $\mathrm{n}^{\circ}$ 35, p. 92; véase también PUPPE, "Vorbemerkungen zu $\S \S 13$ ff", cit. nota ${ }^{\circ} 74$, número marginal 155, así como SCHMIDT-SALZER, Joachim, Produkthaftung - Bd. I Strafrecht, $2^{\mathrm{a}}$ edición, Heidelberg: Recht und Wirtschaft, 1988, número marginal 1.336).

${ }^{157}$ MARBURGER, Die Regeln, cit. nota n ${ }^{\circ} 32$, p. 459; cfr. también en este sentido NICKLISCH, "Technische Regelwerke", cit. nota ${ }^{\circ} 42$, p. 850.

${ }^{158}$ Así MÜLLER-FOELL, Die Bedeutung, cit. nota no 39, p. 105.
} 
Polít. crim. Vol. 13, № 25 (Julio 2018) Art. 11, pp. 387-444.

[http://www.politicacriminal.cl/Vol_13/n_25/Vol13N25A11.pdf]

situación de peligro atípica que hace necesario y exigible cuidados adicionales ${ }^{159}$. Así se ha destacado, por lo demás, en el Derecho penal médico: el facultativo está obligado a comprobar que el correspondiente protocolo o guía de actuación clínica es aplicable al caso que tiene frente a sí, y que no concurre ninguna circunstancia de riesgo propia del paciente que haga indispensable un tratamiento divergente al previsto en la regla ${ }^{160}$. La razón de ello radica en que las pautas médicas se desarrollan para escenarios estándar; en consecuencia, cualquier desviación del caso concreto respecto de aquellos supuestos normales o habituales, obligará al médico a indagar acerca de cuál es el cuidado exigido para el correcto diagnóstico y curación del paciente que tiene a su cargo ${ }^{161}$.

\subsubsection{Creación de riesgos jurídicamente desaprobada por no aplicar capacidades especiales}

Cabe plantearse la pregunta de si el sujeto que cumple con lo previsto en una regla extrajurídica adecuada, no haciendo uso de determinadas capacidades especiales con las que cuenta, genera un riesgo desaprobado para la vida y salud individual. Por capacidades especiales debemos entender aquellas aptitudes para dominar ciertos peligros cuya posesión el Derecho no exige como condición para emprender determinadas actividades riesgosas ${ }^{162}$. Para ilustrar el problema que puede surgir a propósito de la relación entre capacidades especiales y creación de riesgos desaprobados o tolerados en ámbitos donde existen reglamentaciones extrajurídicas, piénsese en el siguiente caso: una norma técnica adecuada prohíbe a los fabricantes de artículos de plástico que sus productos tengan una concentración de tolueno superior a 170 partes por millón ( $\mathrm{ppm}$ ); si un determinado fabricante contara con los recursos económicos necesarios para que los productos que introduce al mercado alcancen una concentración de tolueno de solo 150 ppm, ¿crearía un riesgo desaprobado si no utilizara tales recursos y se limitara a cumplir con la normativa técnica? Si se dispone de una regla extrajurídica capaz de disminuir el riesgo hasta un umbral tal que una persona interesada en la conservación de su vida y salud no dejaría de exponerse al riesgo residual

\footnotetext{
${ }^{159}$ A favor de la existencia de un deber de comprobar si la respectiva norma extrajurídica prevé medidas de cuidado para aquellos peligros que la conducta del sujeto puede previsiblemente desencadenar BOSCH, Organisationsverschulden, cit. nota $\mathrm{n}^{\circ}$ 43, p. 426; FOERSTE, "§ 24. Verkehrspflichten”, cit. nota $\mathrm{n}^{\circ} 154$, número marginal 46; GROßE VORHOLT, Behördliche Stellungnahmen, cit. nota n ${ }^{\circ}$ 24, p. 108; MÜLLERFOELL, Die Bedeutung, cit. nota n 39, p. 110; VEIT, Die Rezeption, cit. nota ${ }^{\circ}$ 42, p. 215. Para el ámbito del Derecho civil véase MARBURGER, Die Regeln, cit. nota no 32, p. 459; MARBURGER, "Die haftungs- und versicherungsrechtliche Bedeutung", cit. nota n ${ }^{\circ} 32$, p. 603; TRATZ, Die zivilprozessuale Bedeutung, cit. nota $\mathrm{n}^{\mathrm{o}} 32$, p. 94.

${ }^{160}$ En este sentido WALTER, Alexander, "Medizinische Leitlinien und Behandlungsfehlerhaftung", GesR 2003, pp. 165-171, p. 168; cfr. también GUÉREZ, El tratamiento médico, cit. nota n 15, p. 151. Dressler llega a afirmar que no es decisivo el estándar (médico) formulado en abstracto, sino solo las características de la situación concreta: únicamente sobre la base de las condiciones dadas en el caso particular, y no a través de reglas generales formuladas para casos típicos planteados en abstracto, se puede responder la pregunta relativa al diagnóstico y tratamiento exigible (DRESSLER, Wolf-Dieter, “Ärztliche Leitlinien und Arzthaftung”, en: BRANDNER, Hans Erich et al (Editores), Festschrift für Karlmann Geiß Zum 65. Geburtstag, Köln: Heymann, 2000, pp. 379-388, p. 381).

161 Así TAUPITZ, "Verbindlichkeit", cit. nota n ${ }^{\circ} 42$, p. 114. Para aludir al cuidado exigido en el caso concreto (que puede apartarse de lo estipulado en un protocolo o guía de actuación clínica) se utiliza la expresión "lex artis ad hoc" (véase, entre otros, FEIJÓO, Resultado lesivo, cit. nota n 17, pp. 312 y ss.; GUÉREZ, El tratamiento médico, cit. nota $\mathrm{n}^{\circ}$ 15, pp. 127 y ss.; ROSAS, Juan, "La delimitación del deber de cuidado en la imputación de responsabilidad penal por imprudencia médica”, Doctrina y Jurisprudencia Penal, N 5 (2011), pp. 3-34, p. 13 y s.; VARGAS, "La imprudencia médica”, cit. nota n 14, p. 114).

${ }^{162}$ Cfr. MURMANN, Grundkurs, cit. nota nº 10, $\$ 23$, número marginal 40.
} 
CONTRERAS, Lautaro. "Reglas extrajurídicas y creaciones de riesgos toleradas o desaprobadas en los delitos culposos de homicidio y lesiones".

subsistente, entonces no parece ser necesaria una restricción adicional a la libertad de acción del destinatario de la regla, basada en la posesión de una capacidad especial. Una restricción semejante supondría la existencia de un interés en tal sentido por parte de los titulares de los bienes jurídicos resguardados. En el ejemplo recién propuesto, el interés de los consumidores difícilmente consistirá en imponer deberes más gravosos que los previstos en la propia norma técnica; si un fabricante de artículos de plástico cuenta con capacidades económicas especiales, los titulares de los bienes jurídicos preferirán, seguramente, que tales capacidades redunden en un precio más bajo de los productos o en innovaciones o mejoras técnicas, puesto que la regulación extrajurídica adecuada ya garantiza un nivel de riesgo suficientemente reducido ${ }^{163}$.

Una limitación a la libertad de actuación adicional a la que pueda surgir de la observancia de una regla extrajurídica - basada en la existencia de una capacidad fuera de lo común- solo podría justificarse en aquellas situaciones en que tal limitación complementaria no afecte de modo significativo los intereses de los titulares del bien jurídico resguardado ni, tampoco, el ejercicio de la libertad de los destinatarios de la regla. Esto ocurrirá frecuentemente en el campo de los diagnósticos y tratamientos médicos. La consideración de una capacidad especial -adquirida, por ejemplo, luego de una larga experiencia en determinado tipo de intervenciones quirúrgicas- para elevar así el estándar de cuidado previsto en una guía médica extrajurídica, no supondrá generalmente una afectación ilegítima en la libertad de los facultativos, menos aún en los intereses de los pacientes ${ }^{164}$. En estos casos, la limitación adicional a la libertad de acción de los médicos se situará en una relación adecuada con los bienes e intereses de los pacientes sometidos al respectivo tipo de operación ${ }^{165}$.

\subsection{Consecuencias de la inobservancia de reglas extrajurídicas adecuadas}

\subsubsection{La creación de riesgos desaprobados}

Si el sujeto se aparta de lo que le exige una regla extrajurídica adecuada, esto es, una regla no estatal que manifieste un justo equilibrio entre los intereses en la mantención de la vida y salud individual, y los intereses en el ejercicio de la libertad, la conducta de aquel deberá calificarse como una creación de riesgo desaprobada jurídicamente, en el sentido de los delitos culposos de resultado de los arts. 490 y 491 del Código Penal ${ }^{166}$.

\footnotetext{
${ }^{163}$ A favor, en cambio, de considerar siempre las capacidades especiales para imponer mayores exigencias que las previstas en reglas técnicas MÜLLER-FOELL, Die Bedeutung, cit. nota nº 39, pp. 155 y ss.

${ }^{164}$ Partidarios de tener en cuenta las capacidades especiales para establecer los deberes de conducta de los médicos, entre otros, FREUND, Strafrecht, cit. nota $n^{\circ}$ 9, § 7, número marginal 31; GÓMEZ, Tratamientos médicos, cit. nota $\mathrm{n}^{\circ}$ 2, p. 359; JORGE, Agustín, La imprudencia punible en la actividad médico-quirúrgica, Madrid: Tecnos, 1990, pp. 42 y 43; ROSAS, “La delimitación del deber”, cit. nota ${ }^{\circ} 161$, pp. 9 y ss.; STERNBERG-LIEBEN; SCHUSTER, "StGB § 15”, cit. nota n 80, número marginal 139.

${ }^{165}$ Como se puede desprender de lo expuesto, la consideración de las capacidades especiales para la configuración de la norma de conducta dependerá del caso en concreto de que se trate, para lo cual deberá responderse la pregunta de si una restricción adicional de la libertad, fundada en la posesión de capacidades extraordinarias, se encuentra -en la situación particular- en una relación adecuada con los intereses en la conservación de bienes y en la libertad del titular del bien jurídico.

${ }^{166}$ Cfr. FRISCH, Tatbestandsmäßiges Verhalten, cit. nota $n^{\circ} 10$, p. 104; de acuerdo con él BRÄUTIGAMERNST, Die Bedeutung von Verwaltungsvorschriften, cit. nota $\mathrm{n}^{\circ} 73$, p. 318; CONTRERAS, Normative Kriterien, cit. nota $\mathrm{n}^{\circ} 92$, p. 148. Naturalmente que para fundar responsabilidad penal por un delito culposo de
} 
Polít. crim. Vol. 13, № 25 (Julio 2018) Art. 11, pp. 387-444.

[http://www.politicacriminal.c1/Vol_13/n_25/Vol13N25A11.pdf]

La circunstancia de que la regla extrajurídica adecuada no sea observada por la generalidad de los sujetos que se desenvuelven en un determinado sector, o incluso por ninguno de ellos, no impide calificar la naturaleza de los riesgos generados por la respectiva actuación como riesgos desaprobados ${ }^{167}$. Una práctica, que lesiona las normas de cuidado necesarias y exigibles para proteger determinados bienes, no deja de apartarse de las prohibiciones o mandatos del ordenamiento jurídico por el hecho de que esté más o menos extendida ${ }^{168}$. La masividad en la infracción de la regla podría únicamente repercutir en la capacidad del sujeto para reconocer el respectivo deber de cuidado, cuando aquel crea erróneamente que las prácticas desarrolladas en su sector se ajustan a las exigencias que impone el Derecho.

5.2.2. Casos de creación de riesgos tolerados pese a la inobservancia de reglas extrajurídicas adecuadas

Existen ciertas constelaciones de casos en los que, no obstante que una conducta ha infringido una regulación extrajurídica adecuada, aquella generará únicamente riesgos permitidos. Se trata de situaciones donde el nivel de seguridad exigido se logra de un modo alternativo al previsto en la regla extrajurídica; y de casos en los que la inobservancia de la regla ha sido mínima o poco significativa, no generándose una situación de incertidumbre para el respectivo bien jurídico.

Respecto de las situaciones en donde el nivel de seguridad exigido se logra de un modo alternativo al contenido en los respectivos programas de reducción de riesgos no estatales ${ }^{169}$, es necesario referirnos a dos modalidades específicas de tales programas: las reglas de la técnica generalmente reconocidas y las reglas médicas.

Por reglas de la técnica generalmente reconocidas debemos entender aquellas reglas técnicas que contienen medidas de limitación o exclusión de peligros cuya eficacia se ha probado en la práctica y que, consiguientemente, son seguidas por la mayoría de los integrantes del respectivo sector. Es frecuente que el contenido de estas reglas no coincida con el estado de la técnica, que está fundado en los más recientes conocimientos de una determinada rama,

resultado no será suficiente la creación de un riesgo desaprobado (surgido de la inobservancia de una norma de conducta no estatal); será indispensable, además, que se cumplan los restantes presupuestos que exige la respectiva norma de sanción, como, por ejemplo, que se esté frente a una negligencia "temeraria" -art. 490 del Código Penal-, que el sujeto activo corresponda a alguno de los indicados en el art. 491 del mismo código, o que el resultado sea la consecuencia específica de la respectiva creación de riesgo.

${ }^{167}$ Cfr. SCHÄFER, Das Recht, cit. nota no 44, p. 153: “[Para apreciar la contrariedad a deber] es totalmente irrelevante el que otros también infrinjan las reglas de la técnica generalmente reconocidas".

168 Cfr. RGSt 39, 2, 5.

${ }^{169}$ Sobre este tipo de casos véase en general FEIJÓO, Resultado lesivo, cit. nota ${ }^{\circ}$ 17, p. 300; LENCKNER, “Technische Normen", cit. nota no 6, pp. 498 y 502; MÜLLER-FOELL, Die Bedeutung, cit. nota n 39, p. 173; SCHMIDT-SALZER, Joachim, Produkthaftung - Bd. III/1 Deliktsrecht 1. Teil, $2^{\text {a }}$ edición, Heidelberg: Recht und Wirtschaft, 1990, número marginal 4.809; SCHÜNEMANN, "Las reglas de la técnica", cit. nota n 3, p. 331; ZIELINSKI, Diethart, Handlungs- und Erfolgsunwert im Unrechtsbegriff - Untersuchungen zur Struktur von Unrechtsbegründung und Unrechtsausschluß, Berlin: Duncker \& Humblot, 1973, p. 173. En el ámbito del Derecho civil MARBURGER, Die Regeln, cit. nota no 32, pp. 440 y 472; MARBURGER, "Die haftungs- und versicherungsrechtliche Bedeutung", cit. nota n³2, p. 603. 
CONTRERAS, Lautaro. "Reglas extrajurídicas y creaciones de riesgos toleradas o desaprobadas en los delitos culposos de homicidio y lesiones".

que no necesariamente han sido puestos en práctica ${ }^{170}$. Pues bien, en la medida que un sujeto despliegue una conducta que se ajuste al estado de la técnica y logre alcanzar, de este modo, el mismo o -incluso- un mejor grado de protección para el bien jurídico que aquel que se hubiera obtenido de haberse acatado la regla de la técnica generalmente reconocida, no creará ningún riesgo jurídicamente desaprobado, pese a la inobservancia de esta ${ }^{171}$. Una solución diferente no solo implicaría el sinsentido de desaprobar conductas que pueden disminuir los peligros para el bien jurídico -en comparación a aquellos comportamientos que se ajustan a los controles de peligros habituales en un determinado sector-, sino además bloquearía por completo el desarrollo técnico ${ }^{172}$. En un sentido similar, en el ámbito específico de la responsabilidad penal médica, se ha señalado que la existencia de reglas del arte generalmente aceptadas en la respectiva especialidad no puede constituir un impedimento para que se adopten procedimientos innovadores, que ofrezcan mejores posibilidades para la curación del paciente ${ }^{173}$; en tales casos no se podrá ver un supuesto de creación de riesgos desaprobados. La posibilidad de realizar ese tipo de procedimientos no sería sino una manifestación de la "libertad de terapia o tratamiento"174.

Sin perjuicio de lo expuesto en el párrafo anterior, debe destacarse la existencia de reglas extrajurídicas que contienen medidas de reducción o eliminación de riesgos de carácter absolutamente elemental, y de tal rigor vinculante, que no será posible para el sujeto concebir cuidados alternativos que ofrezcan el mismo grado de seguridad que el que se alcanzaría con la observancia de la correspondiente regla; así ocurrirá muy frecuentemente con normas extrajurídicas en forma de prohibiciones ${ }^{175}$.

Otra constelación de casos en los que, a pesar de haberse transgredido una reglamentación extrajurídica adecuada, nos encontraremos solo frente a riesgos permitidos -en el sentido de los delitos culposos de homicidio y lesiones corporales de los arts. 490 y 491 del Código Penal- son aquellos en los que la inobservancia de la regla ha sido mínima o poco significativa, no generándose posibilidad alguna de lesión para la vida o salud individual ${ }^{176}$.

\footnotetext{
${ }^{170}$ Sobre los conceptos "reglas de la técnica generalmente reconocidas", "estado de la técnica" y "estado de la ciencia y de la técnica" véase supra nota ${ }^{\circ} 32$.

${ }^{171}$ Véase en este sentido ESSER; KEUTEN, "Strafrechtliche Risiken", cit. nota no 32, p. 318, así como VEIT, Die Rezeption, cit. nota ${ }^{\circ} 42$, pp. 214 y 215.

${ }^{172}$ Acerca de la necesidad de aprobar aquellas conductas que se apartan de las reglas de la técnica reconocidas generalmente, pero que garantizan un nivel de seguridad suficiente, para así no paralizar el desarrollo de la técnica SCHÄFER, Das Recht, cit. nota n ${ }^{\circ}$ 44, p. 153.

${ }^{173}$ Así KATZENMEIER, Christian, Arzthaftung, Tübingen: Mohr Siebeck, 2002, p. 281

${ }^{174}$ Sobre la "libertad de terapia o tratamiento" en detalle FEIJÓO, Resultado lesivo, cit. nota no 17, p. 311 y s., con abundantes citas; GUÉREZ, El tratamiento médico, cit. nota n 15 , pp. 140 y ss.; JORGE, La imprudencia punible, cit. nota ${ }^{\circ} 164$, pp. 45 y ss.; KATZENMEIER, Arzthaftung, cit. nota ${ }^{\circ} 173$, pp. 304 y ss.; SILVA, Jesús María, "La responsabilidad penal del médico por omisión”, La Ley 87-1, pp. 955-966, p. 965.

${ }^{175}$ MARBURGER, Die Regeln, cit. nota n ${ }^{\circ} 32$, p. 470 y s. Piénsese, por ejemplo, en una norma que prohibiera que bloques de hormigón utilizados en la construcción tuvieran grietas u otros defectos visibles, que afectaran su durabilidad y resistencia (cfr. la Nch 181.Of.65, sobre bloques huecos de hormigón de cemento). Es muy difícil concebir medidas alternativas de eliminación de riesgos en un caso semejante.

${ }^{176}$ Cfr. ROXIN, Strafrecht, cit. nota no 2, § 24, número marginal 19; VEIT, Die Rezeption, cit. nota n ${ }^{\circ} 42$, pp. 206, 212 y s.; véase también FEIJÓO, "La imprudencia", cit. nota n ${ }^{2}$, p. 359 (destacando que, en los casos de infracciones mínimas a deberes jurídicos, los problemas que puedan suscitarse han de resolverse aplicando la teoría de la evitabilidad). Para el ámbito del Derecho civil véase MARBURGER, Die Regeln, cit. nota n 32, p. 472.
} 
Polít. crim. Vol. 13, № 25 (Julio 2018) Art. 11, pp. 387-444.

[http://www.politicacriminal.c1/Vol_13/n_25/Vol13N25A11.pdf]

Hay que considerar que para que una conducta pueda ser calificada como típica en el sentido de los delitos imprudentes mencionados, tiene que constituir no solo una violación a una norma extrajurídica; su realización tiene que fundamentar un peligro manifiesto para el bien jurídico, en el sentido de crear una situación de incertidumbre para el mismo ${ }^{177}$. Dicho de otra forma: la ejecución del comportamiento debe traer consigo la posibilidad de acaecimiento del resultado desvalorado; esto solo acontecerá cuando -teniendo a la vista las circunstancias del caso concreto- la lesión al bien jurídico no pueda descartarse como una consecuencia probable del curso causal que desencadenará la respectiva actuación ${ }^{178}$. Un estado de incertidumbre tal respecto de la incolumidad del valor jurídicamente protegido muchas veces no se verificará si la conducta se ha desviado de la regla de un modo irrelevante. Así, por ejemplo, un constructor podría apartarse no significativamente de una norma extrajurídica que lo obligara a que las barras de acero utilizadas al interior de estructuras de hormigón tuvieran un diámetro mínimo. Si la infracción a la norma extrajurídica no conlleva en la situación concreta la posibilidad de lesión para los bienes jurídicos vida o salud individual, entonces no podrá verse en la actuación del constructor una creación de riesgo jurídicamente desaprobada.

5.2.3. Las consecuencias de la infracción de reglas extrajurídicas adecuadas en el plano de la culpabilidad

Con lo expuesto hasta ahora hemos visto que la inobservancia de reglas extrajurídicas, que expresan una adecuada ponderación de intereses, normalmente generará riesgos desaprobados y que, en algunos casos particulares, solo creará riesgos permitidos. Estas consecuencias que surgen de la infracción de reglas de conducta no estatales operan en el plano del injusto de los delitos imprudentes de homicidio y lesiones.

Ahora bien, para algunos, la infracción de reglas extrajurídicas también conllevaría efectos en el ámbito de la culpabilidad de los delitos mencionados, puesto que de tal transgresión se podría deducir siempre que el sujeto contó con la capacidad para cumplir el correspondiente deber de cuidado y prever el resultado lesivo. En lo concerniente a la previsibilidad subjetiva, se señala, expresamente, que si el sujeto conocía la regla extrajurídica que infringión ${ }^{179}$,

${ }^{177}$ Cfr. FRISCH, Tatbestandsmäßiges Verhalten, cit. nota $\mathrm{n}^{\circ} 10$, p. 91.

${ }^{178}$ Cfr. FRISCH, Vorsatz und Risiko, cit. nota n ${ }^{\circ}$ 8, p. 120 y s.; véase también ZIELINSKI, Handlungs- und Erfolgsunwert, cit. nota $\mathrm{n}^{\circ} 169$, p. 173.

${ }^{179}$ El que el sujeto conozca las reglas extrajurídicas aplicables a la situación en que actúa representa una obligación para quien pretende emprender una actividad riesgosa en un ámbito dominado por la ciencia o la técnica (cfr. sentencia del Tribunal Constitucional chileno, de fecha 14 de junio de 2012, ROL 2.154-2011INA, considerando 45: "La parte requirente debía estar en conocimiento de las [normas técnicas] por el hecho de dedicarse a la actividad de la construcción"; véase también BUSTOS, El delito culposo, cit. nota ${ }^{\circ} 40$, p. 48). Considerando que los programas de reducción de riesgos no estatales permiten identificar los peligros para el bien jurídico que podría acarrear la conducta que se pretende desplegar y, especialmente, establecer qué medidas de mitigación han de adoptarse respecto de aquellos peligros, se puede esperar legítimamente que aquel sujeto que pretende realizar una conducta riesgosa en un ámbito dominado por la ciencia o la técnica conozca tales programas (Cfr. MARBURGER, Die Regeln, cit. nota no 32, p. 468; SCHÄFER, Das Recht, cit. nota $\mathrm{n}^{\circ}$ 44, p. 153). Por eso, en el campo de la medicina, los facultativos están obligados a indagar cuál es la lex artis aplicable al procedimiento correspondiente, para lo cual es necesario que se mantengan permanentemente actualizados respecto de los más recientes conocimientos médicos, que puedan hacer exigible un cambio en el cuidado debido (sobre el "deber de perfeccionamiento médico" véase en detalle ULSENHEIMER, Klaus, Arztstrafrecht in der Praxis, 5ª edición, Heidelberg: Müller, 2015, número marginal 120 y s. con múltiples 
CONTRERAS, Lautaro. "Reglas extrajurídicas y creaciones de riesgos toleradas o desaprobadas en los delitos culposos de homicidio y lesiones".

concebida precisamente para evitar los daños generados por el comportamiento desplegado, entonces ya no podrá sostener que el resultado escapaba de lo previsible para él (salvo que se estuviera frente a cursos causales extraordinarios) ${ }^{180}$. Se trata, obviamente, de posturas que establecen el injusto del delito culposo de una manera objetiva, reservando el análisis de las capacidades individuales del autor para el juicio de culpabilidad.

\section{Consecuencias del acatamiento o de la infracción de reglas extrajurídicas inadecuadas}

A continuación, corresponde analizar el efecto que, en el plano del injusto de conducta de los delitos culposos de resultado de los arts. 490 y 491 del Código Penal, tienen el acatamiento y la infracción de reglas extrajurídicas que no reflejan una adecuada ponderación entre los intereses en la mantención de bienes, por una parte, y los intereses en el ejercicio de la libertad, por otra. Para ello, es necesario distinguir entre dos constelaciones de $\operatorname{casos}^{181}$ : supuestos en que la inadecuación de la regla extrajurídica consiste en una exigencia desmesurada al destinatario de la misma, es decir, hipótesis en que la regla impone un gravamen demasiado intenso en favor de la protección de bienes jurídicos (a continuación, infra 6.1.); y casos en que la inadecuación de la regla se basa en que esta no reduce de manera suficiente los peligros para los bienes jurídicos de terceros (infra 6.2.).

\subsection{Reglas extrajurídicas que imponen una exigencia desmedida en aras de la protección del bien jurídico}

Como acertadamente ha destacado Frisch, el Derecho no puede legítimamente exigir al individuo más que la observancia de aquello que en el momento de realización de la conducta se considera como una medida adecuada de reducción de peligros; esto sería totalmente evidente si, a través del establecimiento de una reglamentación extrapenal, el propio Estado fijara una medida semejante ${ }^{182}$. La circunstancia de que el Estado se haya abstenido de dictar una reglamentación extrapenal, dejando a instancias no estatales la elaboración de programas de reducción de riesgos, no puede acarrear ninguna desventaja para el sujeto ${ }^{183}$. En

referencias a doctrina y jurisprudencia alemanas; al respecto también ROMEO, Carlos, El médico ante el Derecho - La responsabilidad penal y civil del médico, Madrid: Servicio de Publicaciones Ministerio de Sanidad y Consumo, 1985, p. 75; ROSAS, "La delimitación del deber", cit. nota n 161, p. 15 y s.).

${ }^{180}$ Cfr. OLG Karlsruhe, NStZ-RR 2000, 141, 142; BOSCH, Organisationsverschulden, cit. nota $n^{\circ}$ 43, p. 423. La relevancia de las normas extrajurídicas para la determinación de la lesión al deber de cuidado subjetivo es destacada también por BOHNERT, Joachim, "Fahrlässigkeitsvorwurf und Sondernorm", JR (1982), pp. 6-11, p. 10; ESSER; KEUTEN, "Strafrechtliche Risiken”, cit. nota n 32, p. 318, así como por SCHÜRER-MOHR, Erlaubte Risiken, cit. nota $\mathrm{n}^{\circ}$ 42, pp. 197 y ss. La doctrina comparada ha llegado a sostener, incluso, que las regulaciones extrajurídicas no desempeñarían ninguna función para valorar cuál es el deber de cuidado objetivo y solo permitirían fundar la reprochabilidad personal (así BOSCH, Organisationsverschulden, cit. nota n ${ }^{\circ} 43$, p. 426). La importancia de la infracción de deberes de conducta en el plano de la previsibilidad ha sido destacada entre nosotros por Hernández: “...en general no puede sostenerse seriamente que sea imprevisible un resultado lesivo cuando éste es de aquéllos a cuya evitación tiende precisamente la normativa infringida." (HERNÁNDEZ, Héctor, "Apuntes sobre la responsabilidad penal (imprudente) de los directivos de empresa", Revista de Estudios de la Justicia, № 10, Año 2008, pp. 175-198, p. 182).

${ }^{181}$ La distinción se puede encontrar en FRISCH, Tatbestandsmäßiges Verhalten, cit. nota $\mathrm{n}^{\circ} 10$, p. 109. En favor de aplicar la diferenciación en materia de reglas de seguridad de productos extrajurídicas CONTRERAS, Normative Kriterien, cit. nota ${ }^{\circ}$ 92, p. 149.

${ }^{182}$ Así FRISCH, Tatbestandsmäßiges Verhalten, cit. nota nº 10, p. 111 (pie de página 59).

${ }^{183}$ En este sentido FRISCH, Tatbestandsmäßiges Verhalten, cit. nota nº 10, p. 111 (pie de página 59). 
Polít. crim. Vol. 13, № 25 (Julio 2018) Art. 11, pp. 387-444.

[http://www.politicacriminal.cl/Vol_13/n_25/Vol13N25A11.pdf]

consecuencia, la pauta para enjuiciar el carácter desaprobado o no de los riesgos creados por una conducta no puede estar dada por una normativa extrajurídica que exija inadecuadamente en exceso, sino solo por aquella reglamentación que pueda ser percibida como el resultado de una adecuada ponderación de intereses ${ }^{184}$. Por eso, no podrá apreciarse ningún injusto de conducta -en el sentido de los delitos culposos de resultado de los arts. 490 y 491 del Código Penal- si el cumplimiento de una regla extrajurídica que impone una exigencia desmedida hubiera evitado ciertas afectaciones a bienes jurídicos, pero la respectiva actuación, bajo la observancia de reglas adecuadas, no representa ningún aumento de riesgo relevante ${ }^{185}$.

\subsection{Reglas extrajurídicas que ofrecen una protección insuficiente del bien jurídico}

La falta de adecuación de una regla extrajurídica, que no reduce de manera suficiente los peligros para el bien jurídico, puede tener su origen en motivos diversos. Es posible que la regulación no estatal contemple medidas de disminución de riesgos que hayan quedado obsoletas con el tiempo, a causa del avance científico o tecnológico; este será el caso más frecuente. Puede ocurrir, también, que la normativa no estatal se haya mostrado desde su dictación insuficiente para el resguardo de bienes jurídicos, ya sea por una incorrecta evaluación de la eficacia de la normativa, o porque en forma deliberada se privilegiaron desmedidamente los intereses en la libertad de acción del destinatario de la regla ${ }^{186}$.

Para analizar el efecto que, en el plano del injusto de comportamiento del delito culposo, acarrea el acatamiento de un programa de reducción de riesgos no estatal que impone una protección insuficiente del bien jurídico, es necesario distinguir dos supuestos diferentes. Por una parte, casos en que, en el momento de realización de la conducta enjuiciada, el programa de disminución de riesgos ya podía ser considerado como inadecuado para el resguardo de bienes jurídicos; por otra, casos donde la inadecuación solo se pone de manifiesto con posterioridad a la ejecución de la conducta objeto de calificación jurídica ${ }^{187}$.

6.2.1. La inadecuación de la regla extrajurídica ya es evidente en el momento de desplegar la conducta

Si en el momento de ejecución de la conducta la inadecuación de la regla extrajurídica ya era evidente para el círculo de expertos, sea por la obsolescencia de la respectiva medida de reducción de riesgos, sea porque esta desde un comienzo se mostró insuficiente para la protección del bien jurídico, la actuación que se ajuste a la regla creará un riesgo desaprobado en el sentido de los delitos culposos de resultado de los arts. 490 y 491 del Código Penal ${ }^{188}$.

\footnotetext{
${ }^{184}$ Véase FRISCH, Tatbestandsmäßiges Verhalten, cit. nota $\mathrm{n}^{\mathrm{o}} 10, \mathrm{p} .110$.

${ }^{185}$ Cfr. FRISCH, Tatbestandsmäßiges Verhalten, cit. nota $\mathrm{n}^{\circ}$ 10, p. 110; de acuerdo con él CONTRERAS, Normative Kriterien, cit. nota ${ }^{\circ} 92$, p. 149 y s.

${ }^{186}$ Como se señaló (supra nota $n^{\circ} 86$ ), en la medida que en la instancia privada que creó la regla se hayan visto representados los distintos intereses afectados por la regulación, y se haya contado en el proceso de elaboración con una asesoría técnica o científica idónea, se tratará de una situación muy poco frecuente.

${ }^{187}$ Véase FRISCH, Tatbestandsmäßiges Verhalten, cit. nota $\mathrm{n}^{\circ} 10$, p. 110.

${ }^{188}$ Cfr. ALEXANDER, Die strafrechtliche Verantwortlichkeit, cit. nota ${ }^{\circ}$ 35, p. 92; COLOMBI CIACCHI, Aurelia, Fahrlässigkeit und Tatbestandsbestimmtheit Deutschland und Italien im Vergleich, Köln: Carl Heymanns, 2005, p. 94; LENCKNER, “Technische Normen”, cit. nota nº 6, p. 501; VEIT, Die Rezeption, cit. nota $\mathrm{n}^{\circ}$ 42, p. 204 y s. Para el ámbito del Derecho penal médico véase ULSENHEIMER, Arztstrafrecht, cit. nota $\mathrm{n}^{\circ} 179$, número marginal 62 y s. Sobre los efectos en la responsabilidad civil de la observancia de una regla extrajurídica que, al momento de realización de la conducta, ya se mostraba inadecuada véase SCHÄFER, Das Recht, cit. nota n 44, p. 137 así como TRATZ, Die zivilprozessuale Bedeutung, cit. nota no 32, p. 94 y s.
} 
CONTRERAS, Lautaro. "Reglas extrajurídicas y creaciones de riesgos toleradas o desaprobadas en los delitos culposos de homicidio y lesiones".

Ejemplo: una norma técnica, que detalla las advertencias que deben acompañarse a los manuales de instrucciones de monitores respiratorios, no incluye el aviso del peligro de electrocución que supone la incorrecta manipulación del cable de electrodos del aparato; el correspondiente círculo de fabricantes reconoce la deficiencia de la norma y propone a la instancia que dictó la regulación una modificación de la misma. En el intertanto, se siguen distribuyendo monitores respiratorios sin la correspondiente advertencia, lo que termina provocando la muerte de un paciente ${ }^{189}$. En este caso deberá verse un supuesto de creación de riesgos desaprobada jurídicamente.

Sin perjuicio de que el acatamiento de una regla extrajurídica, que se muestra como inadecuada al momento de realización de la conducta para la protección de bienes jurídicos, permita fundar la creación de un riesgo no tolerado y, con ello, normalmente, la tipicidad del delito culposo, es posible que el reproche de culpabilidad imprudente decaiga si el individuo no estuvo en condiciones de reconocer el defecto de la reglamentación extrajurídica. Concretamente: si el sujeto confiaba en la corrección de una norma extrajurídica objetivamente inadecuada, la actuación realizada por este será contraria a deber; sin embargo, no podrá reprocharse el injusto realizado por concurrir un error inevitable sobre el contenido del deber de cuidado (error de prohibición) ${ }^{190}$. En un caso donde se investigaba la responsabilidad penal por las numerosas muertes y lesiones provocadas por el derrumbe en el año 1971 de un puente que cruzaba el río Rin, el ministerio público alemán decidió no acusar a quien había diseñado los planos de la estructura, ni tampoco al ingeniero calculista, precisamente porque - a pesar de los defectos de que adolecía la norma DIN 4114, aplicada para calcular la resistencia del puente- los imputados no tuvieron ningún motivo para dudar de la corrección de esta normativa ${ }^{191}$.

Por regla general, el sujeto puede confiar en que los programas no estatales de reducción de riesgos están libres de errores o defectos ${ }^{192}$; en consecuencia, no existe un deber jurídico de

\footnotetext{
${ }^{189}$ Cfr. sentencia civil del Tribunal Supremo Federal alemán, pronunciada el 27 de septiembre de 1994 y publicada en $N J W$ 1994, pp. 3349 y ss. Otros casos de la jurisprudencia civil alemana donde se dio por establecida una infracción al cuidado debido, por haberse cumplido con normas extrajurídicas que ofrecían una protección insuficiente para el bien jurídico, pueden encontrarse en BGH NJW 1984, 801 y ss., así como en OLG Düsseldorf VersR 1987, 414 y s.

190 Así SCHUMANN, Heribert, Strafrechtliches Handlungsunrecht und das Prinzip der Selbstverantwortung der Anderen, Tübingen: Mohr Siebeck, 1986, p. 126 y s. En un sentido muy similar LENCKNER, "Technische Normen", cit. nota $\mathrm{n}^{\circ}$ 6, p. 503 y s. Para los partidarios de la teoría de la contrariedad a deber individual, la falta de capacidad del sujeto para reconocer el carácter inadecuado de la reglamentación extrajurídica impide afirmar ya un injusto de conducta (en este sentido BOSCH, Organisationsverschulden, cit. nota n ${ }^{\circ}$ 43, p. 424 [nota 1.350] así como SCHAUMANN-WERDER, Hedda v., Strafrechtliche Produkthaftung im Europäischen Binnenmarkt - Der Einfluss europäischer Instrumente zur Herstellung und Aufrechterhaltung des Binnenmarktes, Köln: Carl Heymanns, 2008, p. 142 (nota 737)).

${ }^{191}$ El caso es recogido por SCHMIDT-SALZER, Produkthaftung, cit. nota $\mathrm{n}^{\circ}$ 156, número marginal 1.342, y comentado por BOSCH, Organisationsverschulden, cit. nota n ${ }^{\circ}$ 43, p. 424 y s.; MÜLLER-FOELL, Die Bedeutung, cit. nota $\mathrm{n}^{\mathrm{0}}$ 39, p. 157 (para quien el ingeniero calculista debería haber examinado la corrección de la norma DIN 4114, puesto que la actividad de construcción de puentes genera riesgos especialmente importantes); VEIT, Die Rezeption, cit. nota $\mathrm{n}^{\circ}$ 42, p. 205.

192 Véase en este sentido BOSCH, Organisationsverschulden, cit. nota no 43, p. 426; LENCKNER, "Technische Normen", cit. nota $n^{\circ}$ 6, p. 504; VEIT, Die Rezeption, cit. nota n 42, p. 205 y s. De otra opinión MÜLLERFOELL, Die Bedeutung, cit. nota n ${ }^{\circ}$ 39, p. 156 y s. (la confianza en la corrección de la regla extrajurídica no estaría amparada por el Derecho en aquellos casos en que el potencial de riesgo de la actividad regulada es
} 
Polít. crim. Vol. 13, № 25 (Julio 2018) Art. 11, pp. 387-444.

[http://www.politicacriminal.cl/Vol_13/n_25/Vol13N25A11.pdf]

examinar si las medidas de limitación de riesgos previstas en la correspondiente regulación son correctas o suficientes. La única obligación que pesa sobre el sujeto es comprobar si el contenido de la norma extrajurídica es aplicable al caso concreto, es decir, verificar si la norma prevé medidas de mitigación para aquellos riesgos que previsiblemente puede desencadenar la actuación, y no concurren peligros atípicos, que requieren medidas de cuidado especiales; hecha esta comprobación, el Derecho no puede legítimamente imponer un deber (adicional) de verificar la corrección de la regla no estatal ${ }^{193}$. En muchos casos el sujeto no tendrá los conocimientos o recursos económicos necesarios para llevar a cabo una verificación semejante; procurarse unos u otros conllevaría una carga para el ejercicio de la libertad no legitimable. La protección de la confianza en la corrección de la regla extrajurídica tiene que adoptar especial intensidad tratándose de reglas codificadas (verbigracia, normas chilenas). Y es que este tipo de reglamentaciones son elaboradas por comisiones integradas por expertos y representantes de los diversos intereses afectados con la dictación de la normativa (entre ellos, delegados de asociaciones de usuarios o consumidores), existiendo, además, instancias de consulta pública; todo ello garantiza que la regla que se dicte estará libre de defectos, permitiéndose alcanzar un adecuado nivel de protección ${ }^{194}$. Con todo, la protección de la confianza en la corrección de la normativa

especialmente elevado). En el ámbito del Derecho civil categórico en favor de la confianza SCHÄFER, Das Recht, cit. nota $\mathrm{n}^{\circ}$ 44, p. 143.

${ }^{193}$ Así MARBURGER, Die Regeln, cit. nota n 32, p. 467.

${ }^{194}$ Cfr. MARBURGER, Die Regeln, cit. nota n ${ }^{\circ} 32$, p. 467; SCHUMANN, Strafrechtliches Handlungsunrecht, cit. nota ${ }^{\circ} 190$, p. 128. En caso de que la norma técnica codificada adoleciera de incorrecciones y la aplicación bona fide de la misma condujera a un resultado lesivo, se podría plantear el problema concerniente a la responsabilidad penal a título de homicidio o lesiones culposos de quienes dictaron la norma técnica inadecuada. Al respecto, es difícil cuestionar la vigencia de un deber jurídico que obliga a los creadores de programas normativos no estatales a dictar regulaciones que cumplan con una eficacia mínima la finalidad de protección de la vida y salud individual. Y ello no solo por la importancia de los bienes en juego, sino además porque quienes dictan normas técnicas semejantes se colocan voluntariamente en una especial posición de confianza frente al destinatario de la regulación, ofreciéndole instrucciones dotadas de una alta calidad y capaces de dominar peligros relevantes para bienes ajenos (cfr. LENCKNER, "Technische Normen", cit. nota n ${ }^{\circ}$ 6, p. 507; en un sentido similar SCHUMANN, Strafrechtliches Handlungsunrecht, cit. nota n ${ }^{\circ}$ 190, p. 128). El individuo que acata tales instrucciones prescinde de la adopción de otras medidas de cuidado, confiando en la autoridad de la instancia normativa privada. Por todo lo anterior, es claro que esa instancia está obligada jurídicamente a ofrecer medidas eficaces de reducción de riesgos. Ahora bien, para afirmar la responsabilidad penal por homicidio o lesiones imprudentes tendrá que verificarse no solo la infracción al mencionado deber jurídico de cuidado, sino además comprobarse previamente que la conducta del respectivo miembro de la instancia normativa que dictó la regla extrajurídica fue condición necesaria para el resultado lesivo. Esta constatación puede ser particularmente difícil si se tiene en cuenta que el proceso de dictación de reglas extrajurídicas recae en un colectivo de personas y que el rendimiento de la fórmula de la conditio sine qua non puede ser muy limitado tratándose de la adopción de decisiones gremiales (respecto de la causalidad en las decisiones colegiadas la literatura es muy abundante; véase, entre otros BLOY, René, "Die strafrechtliche Produkthaftung auf dem Prüfstand der Dogmatik", en: BLOY, René et al (Editores), Gerechte Strafe und legitimes Strafrecht Festschrift für Manfred Maiwald zum 75. Geburtstag, Berlin: Duncker \& Humblot, 2010, pp. 35-59, pp. 53 y ss.; KUHLEN, Lothar, "Strafhaftung bei unterlassenem Rückruf gesundheitsgefährdender Produkte Zugleich Anmerkung zum Urteil des BGH vom 6. 7. 1990 - 2 StR 549/89 (NStZ 1990, 588)", NStZ (1990), pp. 566-570, p. 569 y s.; PUPPE, Ingeborg, “Anmerkungen zu BHGSt 37, 106”, JR (1992), pp. 30-34, pp. 32 y ss.; SAMSON, Erich, "Probleme strafrechtlicher Produkthaftung", StV (1991), pp. 182-186, p. 184 y s.; SCHMUCKER, Andrea, Die „Dogmatik“ einer strafrechtlichen Produktverantwortung, Frankfurt am Main: Peter Lang, 2001, pp. 218 y ss.). Por lo que respecta a las lesiones corporales culposas, se presenta una dificultad adicional para el castigo del responsable por la dictación de regulaciones técnicas inadecuadas: tratándose de las lesiones graves del art. 397 del Código Penal chileno solo cabe castigar las conductas de herir, golpear o maltratar de 
CONTRERAS, Lautaro. "Reglas extrajurídicas y creaciones de riesgos toleradas o desaprobadas en los delitos culposos de homicidio y lesiones".

extrajurídica no rige en caso de concurrir conocimientos especiales; si para el individuo es evidente, sin que sea necesario realizar un examen de la regulación, que esta no ofrece una protección adecuada para los bienes jurídicos vida o salud individual y, pese a ello, orienta su acción conforme a lo indicado en la normativa, entonces deberá verse en su conducta una creación de riesgo desaprobada ${ }^{195}$. En este caso, existe un legítimo interés de las personas potencialmente afectadas en sus bienes por el comportamiento ajustado a la normativa defectuosa, en que la libertad de acción del individuo que dispone del conocimiento especial se limite. Este interés ha de preponderar en atención a la importancia de los bienes jurídicos amenazados.

6.2.2. La inadecuación de la regla extrajurídica se pone de manifiesto luego de la realización del comportamiento

Hasta ahora hemos analizado el efecto que acarrea en el plano del injusto de conducta imprudente el acatamiento de un programa de reducción de riesgos no estatal que, en el momento de realización del comportamiento enjuiciado, ya podía ser considerado como inadecuado para el resguardo de bienes jurídicos. Corresponde ahora referirnos a aquellos casos en que la inadecuación solo se pone de manifiesto con posterioridad a la ejecución de la conducta.

Si la inadecuación de la regla extrajurídica solo se vuelve evidente después de desplegar el respectivo comportamiento, entonces esta no podrá verse como la creación de un riesgo desaprobado, en el sentido de los delitos culposos de resultado de los arts. 490 y 491 del Código Penal. El Derecho no puede legítimamente exigir al sujeto más allá de la observancia de aquello que en el momento de su actuación era considerado por el respectivo círculo de expertos como una medida suficiente de reducción de peligros ${ }^{196}$. Esto es una consecuencia de la teoría del injusto de conducta determinable (solo) ex ante: el objeto de las normas prohibitivas puede ser únicamente un comportamiento que, en el instante de su ejecución y de acuerdo con la experiencia de vida general, encierra una tendencia lesiva ${ }^{197}$. Tal disposición no se puede apreciar respecto de una acción que cumple con una regla extrajurídica considerada en el momento de la conducta como objetivamente adecuada. En consecuencia, si (solo) después de acaecer el resultado se demuestra que la regulación no estatal era incorrecta o insuficiente para la reducción de peligros, no podrá afirmarse la tipicidad objetiva del delito culposo de homicidio o lesiones corporales ${ }^{198}$.

\footnotetext{
obra, en las que -salvo el recurso a una analogía inadmisible- no cabe subsumir la actuación de dictar reglas técnicas defectuosas (en favor, en cambio, de un interpretación amplia de las conductas típicas que pueden causar alguno de los resultados previstos en el art. 397 del Código Penal MERA, Jorge, "Los medios en el delito de lesiones graves (Art. 397 del C.P.)", Revista de Ciencias Penales, Tomo XXXIV (1975), pp. 163-200, pp. 182 y ss.). Sobre la responsabilidad civil que puede surgir a partir de la dictación de reglas técnicas inadecuadas véase HERSCHEL, Wilhelm, Rechtsfragen der Technischen Überwachung, $2^{\mathrm{a}}$ edición, Heidelberg: Recht und Wirtschaft, 1980, p. 136 y s.; MARBURGER, Die Regeln, cit. nota nº 32, pp. 537 y ss.

${ }^{195}$ Véase KUHLEN, Fragen, cit. nota n ${ }^{\circ}$ 84, p. 106.

${ }^{196}$ Así FRISCH, Tatbestandsmäßiges Verhalten, cit. nota ${ }^{\circ} 10$, p. 110 y s.

${ }^{197}$ Sobre la perspectiva ex ante en Derecho penal véase, entre otros, FREUND, Erfolgsdelikt, cit. nota n ${ }^{\circ} 78$, p. 56 y s., 60; FREUND, Strafrecht, cit. nota $\mathrm{n}^{\circ}$ 9, § 7, números marginales 23 y ss., 34 y 41; FRISCH, Tatbestandsmäßiges Verhalten, cit. nota $\mathrm{n}^{\mathrm{0}} 10$, pp. 34, 41 y s., 71 y ss.

${ }^{198}$ En este sentido FEIJÓO, Resultado lesivo, cit. nota no 17, p. 315 y s.
} 
Polít. crim. Vol. 13, № 25 (Julio 2018) Art. 11, pp. 387-444.

[http://www.politicacriminal.c1/Vol_13/n_25/Vol13N25A11.pdf]

La imposibilidad de adoptar una perspectiva ex post para constatar la existencia de un injusto de conducta imprudente ha sido especialmente destacada en el Derecho penal médico: "circunstancias que se vuelven conocidas después, nuevos desarrollos y experiencias clínicas, conocimientos científicos y resultados de investigaciones posteriores, no pueden servir para incriminar a un médico (...)"199; la lex artis, que permite enjuiciar el carácter desaprobado o tolerado del riesgo creado por la conducta del facultativo, solo puede ser aquella vigente en el momento del respectivo diagnóstico o tratamiento.

La determinación de la norma de conducta aplicable bajo una estricta observancia de la perspectiva ex ante parece ser un lugar común como exigencia teórica; en la práctica de los operadores jurídicos puede no constituir algo evidente ${ }^{200}$. Investigaciones de la psicología social han mostrado que en una sociedad de riesgo siempre existe la tendencia a atribuir responsabilidad a partir de una orientación inadmisible hacia el resultado ${ }^{201}$. Allí donde acaece un daño comienza la búsqueda de un responsable, el que normalmente termina encontrándose ${ }^{202}$. Los sucesos negativos parecen tolerarse de mejor forma cuando se puede imputar responsabilidad a alguien por ellos, aunque sea de un modo injusto ${ }^{203}$. Para hacer frente a esta tendencia es imperioso fijar las normas de conducta solo a partir de los conocimientos nomológicos o datos empíricos existentes al momento de actuar, dejando al margen todo tipo de circunstancia que no haya podido ser conocida por el sujeto en ese instante.

\section{Síntesis}

En la medida que la regla extrajurídica ( $i$ ) busque evitar precisamente aquella situación de riesgo que ha conducido al resultado típico, y (ii) sea la manifestación de un vínculo recíprocamente aceptable entre los intereses del destinatario de la regulación y los bienes e intereses del sujeto beneficiado con las medidas de control de riesgos previstas en ella, dicha regla permitirá distinguir entre riesgos jurídicamente tolerados y desaprobados, en el sentido de los delitos culposos de los arts. 490 y 491 del Código Penal. De este modo, el riesgo residual que subsista pese a la observancia de la regla extrajurídica deberá estimarse generalmente como tolerado; el comportamiento que no observe la regla, por el contrario, conllevará usualmente una creación desaprobada de peligros.

\footnotetext{
199 Así ULSENHEIMER, Arztstrafrecht, cit. nota no 179, número marginal 80; cfr. también SCHROTH, Ulrich, "Die strafrechtliche Verantwortlichkeit des Arztes bei Behandlungsfehlern", en: ROXIN, Claus; SCHROTH, Ulrich (editores), Handbuch des Medizinstrafrechts, $2^{\mathrm{a}}$ edición, Stuttgart: Richard Boorberg, 2010, pp. 125160, p. 147. En el ámbito del Derecho civil véase KATZENMEIER, Arzthaftung, cit. nota no 173 , pp. 169 y s., 411, así como TAUPITZ, "Verbindlichkeit", cit. nota $\mathrm{n}^{\mathrm{o}} 42$, p. 111, ambos con ulteriores referencias a la jurisprudencia y doctrina civil alemanas.

${ }^{200}$ En este sentido BLOY, "Die strafrechtliche Produkthaftung", cit. nota no 194, p. 42.

${ }^{201}$ Así PRITTWITZ, Cornelius, Strafrecht und Risiko - Untersuchungen zur Krise von Strafrecht und Kriminalpolitik in der Risikogesellschaft, Frankfurt am Main: Klostermann, 1993, pp. 108 y 381.

${ }^{202}$ BLOY, "Die strafrechtliche Produkthaftung", cit. nota $\mathrm{n}^{\circ}$ 194, p. 42. Acerca de este fenómeno en detalle KUHLEN, Lothar, "Zur Problematik der nachträglichen ex ante-Beurteilung im Strafrecht und in der Moral”, en: JUNG, Heike et al (Editores), Recht und Moral - Beiträge zu einer Standortbestimmung, Baden-Baden: Nomos, 1991, pp. 341-372, pp. 358 y ss.; PRITTWITZ, Strafrecht und Risiko, cit. nota n 201, pp. 107 y ss., 360 y ss., 378 y ss.

${ }^{203}$ Véase PRITTWITZ, Strafrecht und Risiko, cit. nota nº 201, p. 108.
} 
CONTRERAS, Lautaro. "Reglas extrajurídicas y creaciones de riesgos toleradas o desaprobadas en los delitos culposos de homicidio y lesiones".

En la generalidad de los casos, el juez penal puede partir del supuesto de que los intereses del destinatario de una regla extrajurídica -que no se encuentre obsoleta-, y los bienes e intereses del sujeto beneficiado con las medidas de control previstos en ella, están situados en una relación mutuamente razonable. Efectivamente, la observancia de las reglamentaciones extrajurídicas previene en una inmensa mayoría de casos el desencadenamiento de cursos lesivos; además, de la circunstancia de que los programas de reducción de riesgos no estatales se cumplan normalmente por sus destinatarios, se puede desprender que aquellos no imponen medidas inexigibles ${ }^{204}$. Esta "presunción de adecuación" de los programas no estatales de reducción de riesgos explicaría por qué con tanta frecuencia los tribunales fundan la creación de riesgos tolerados o desaprobados (= la observancia o inobservancia del deber de cuidado) únicamente en la desviación o acatamiento de lo previsto en tales programas, sin llevar a cabo un juicio valorativo adicional de los mismos ${ }^{205}$. De este modo, en la aplicación de los tipos culposos de homicidio y lesiones (arts. 490 y 491 del Código Penal, en relación con las respectivas normas del T. VIII del L. II del mismo código), las reglas extrajurídicas revisten una importancia equivalente a la que tienen las reglas extrapenales en la delimitación entre riesgos tolerados o desaprobados.

\footnotetext{
${ }^{204}$ Véase FRISCH, Tatbestandsmäßiges Verhalten, cit. nota n ${ }^{\circ}$ 10, p. 106.

${ }^{205}$ Cfr. ELSTER, Ärztliche Leitlinien, cit. nota n ${ }^{\circ}$ 42, p. 91.
} 
Polít. crim. Vol. 13, No 25 (Julio 2018) Art. 11, pp. 387-444.

[http://www.politicacriminal.cl/Vol_13/n_25/Vol13N25A11.pdf]

\section{Bibliografía}

ALEXANDER, Thorsten, Die strafrechtliche Verantwortlichkeit für die Wahrung der Verkehrssicherungspflichten in Unternehmen, Herbolzheim: Centaurus, 2005.

ÁLVAREZ, Vicente, La normalización industrial, Valencia: Tirant lo Blanch, 1999.

BACHMANN, Gregor, Private Ordnung, Tübingen: Mohr Siebeck, 2006.

BLOY, René, "Die strafrechtliche Produkthaftung auf dem Prüfstand der Dogmatik", en: BLOY, René et al (Editores), Gerechte Strafe und legitimes Strafrecht-Festschrift für Manfred Maiwald zum 75. Geburtstag, Berlin: Duncker \& Humblot, 2010, p. 35-59.

BOHNERT, Joachim, “Fahrlässigkeitsvorwurf und Sondernorm”, JR (1982), pp. 6-11.

BOREAN, Damián, Las reglas técnicas de la construcción en el Derecho penal alemánUn aporte al análisis constitucional de tipos abiertos y a la concreción del deber de cuidado en delitos imprudentes, Buenos Aires: Ad-Hoc, 2015.

BOSCH, Nikolaus, Organisationsverschulden in Unternehmen, Baden-Baden: Nomos, 2002.

BRÄUTIGAM-ERNST, Stephanie, Die Bedeutung von Verwaltungsvorschriften für das Strafrecht - Dargestellt am Beispiel der $\$ \S 325,325 a$ StGB und der Technischen Anleitungen des Immissionsschutzrechts, Baden-Baden: Nomos, 2010.

BURGSTALLER, Manfred, Das Fahrlässigkeitsdelikt im Strafrecht - Unter besonderer Berücksichtigung der Praxis in Verkehrssachen, Wien: Manzsche Verlags- und Universitätsbuchhandlung, 1974.

BUSTOS, Juan, El delito culposo, Santiago: Editorial Jurídica de Chile, 1995.

CARRILLO, Juan, El Derecho de la seguridad y de la calidad industrial, Madrid: Marcial Pons, 2000.

COLOMBI CIACCHI, Aurelia, Fahrlässigkeit und Tatbestandsbestimmtheit, Köln: Heymann, 2005.

CONTRERAS, Lautaro, Normative Kriterien zur Bestimmung der Sorgfaltspfichten des Produzenten, Berlin: Duncker \& Humblot, 2012.

CORCOY, Mirentxu, El delito imprudente - Criterios de imputación del resultado, Barcelona: PPU, 1989.

CORDERO, Luis, Lecciones de Derecho administrativo, $2^{\text {a }}$ edición, Santiago de Chile: Legal Publishing Chile, 2015. 
CONTRERAS, Lautaro. "Reglas extrajurídicas y creaciones de riesgos toleradas o desaprobadas en los delitos culposos de homicidio y lesiones".

DOMEIER, Danja, Gesundheitsschutz und Lebensmittelstrafrecht, Frankfurt am Main: Peter Lang, 1999.

DONATSCH, Andreas, Sorgfaltsbemessung und Erfolg beim Fahrlässigkeitsdelikt, Zürich: Schulthess Polygraphischer Verlag, 1987.

DRESSLER, Wolf-Dieter, “Ärztliche Leitlinien und Arzthaftung”, en: BRANDNER, Hans Erich et al (Editores), Festschrift für Karlmann Geiß Zum 65. Geburtstag, Köln: Heymann, 2000, pp. 379-388.

EISELE, Jörg, "Vorbemerkungen zu den $\S \S 13$ ff.", en: Schönke/Schröder Strafgesetzbuch Kommentar, 29ª edición, München: C. H. Beck, 2014.

ELSTER, Tobias, Ärztliche Leitlinien in der vertraglichen Arzthaftung - Eine Untersuchung materiell-rechtlicher und prozessualer Aspekte unter besonderer Berücksichtigung des medizinischen Standards, Frankfurt am Main: Peter Lang, 2004.

ESSER, Robert; KEUTEN, Nils Christian, "Strafrechtliche Risiken am Bau - Überlegungen zum Tatbestand der Baugefährdung ( $\$ 319 \mathrm{StGB})$ und seinem Verhältnis zu §§ 222, 229 StGB”, NStZ (2011), pp. 314-322.

ESTEVE, José, Técnica, riesgo y Derecho - Tratamiento del riesgo tecnológico en el derecho ambiental, Barcelona: Ariel, 1999.

FEIJÓO, Bernardo, “La imprudencia en el Código Penal de 1995 (cuestiones de 'lege lata' y de 'lege ferenda')", $C P C$ n $^{\circ} 62$ (1997), pp. 303-365.

FEIJÓO, Bernardo, Resultado lesivo e imprudencia - Estudio sobre los límites de la responsabilidad penal por imprudencia y el criterio del "fin de protección de la norma de cuidado”, Barcelona: Bosch, 2001.

FERNÁNDEZ, José, "El delito imprudente: la determinación de la diligencia debida en el seno de las organizaciones", Revista de Derecho (Universidad Austral de Chile), Vol. XIII (2002), pp. 101-121.

FOERSTE, Ulrich, "§ 24. Verkehrspflichten im Bereich der Warenherstellung”, en: GRAF V. WESTPHALEN, Friedrich (Editor), Produkthaftungshandbuch, $3^{\text {a }}$ edición, München: C. H. Beck, 2012, pp. 381-524.

FREUND, Georg, "Richtiges Entscheiden am Beispiel der Verhaltensbewertung aus der Perspektive des Betroffenen, insbesondere im Strafrecht - Zugleich ein Beitrag zur Relativität objektiver Daten", GA (1991), pp. 387-410.

FREUND, Georg, Erfolgsdelikt und Unterlassen, Köln: Heymann, 1992. 
Polít. crim. Vol. 13, No 25 (Julio 2018) Art. 11, pp. 387-444.

[http://www.politicacriminal.c1/Vol_13/n_25/Vol13N25A11.pdf]

FREUND, Georg, "Täuschungsschutz und Lebensmittelstrafrecht Grundlagen und Perspektiven", ZLR (1994), pp. 261-304.

FREUND, Georg, "Die Definitionen von Vorsatz und Fahrlässigkeit - Zur Funktion gesetzlicher Begriffe und ihrer Definition bei der Rechtskonkretisierung”, en HETTINGER, Michael et al (Editores), Festschrift für Wilfried Küper zum 70. Geburtstag, Heidelber: Müller, 2007, pp. 63-82.

FREUND, Georg, Strafrecht Allgemeiner Teil, 2ª edición, Berlin: Springer, 2009.

FRISCH, Wolfgang, Vorsatz und Risiko Grundfragen des tatbestandsmäßigen Verhaltens und des Vorsatzes - Zugleich ein Beitrag zur Behandlung außertatbestandlicher Möglichkeitsvorstelllungen, Köln: Carl Heymanns, 1983.

FRISCH, Wolfgang, Tatbestandsmäßiges Verhalten und Zurechnung des Erfolgs, Heidelberg: Müller, 1988.

FRISCH, Wolfgang, "Gegenwartsprobleme des Vorsatzbegriffs und der Vorsatzfeststellung am Beispiel der AIDS-Diskussion", en: GEPPERT, Klaus; DEHNICKE, Diether (Editores), Gedächtnisschrift für Karlheinz Meyer, Berlin: Walter de Gruyter, 1990, pp. 533-566.

FRISCH, Wolfgang, "Selbstgefährdung im Strafrecht - Grundlinien einer opferorientierten Lehre vom tatbestandsmäßiges Verhalten”, NStZ (1992), pp. 1-7, 62-67.

FRISCH, Wolfgang, Verwaltungsakzessorietät und Tatbestands-verständnis im Umweltstrafrecht Zum Verhältnis von Umweltverwaltungsrecht und Strafrecht und zur strafrechtlichen Relevanz behördlicher Genehmigungen, Heidelberg: Müller, 1993.

FRISCH, Wolfgang, "Problemas fundamentales de la responsabilidad penal de los órganos de dirección de la empresa - Responsabilidad penal en el ámbito de la responsabilidad de la empresa y de la división del trabajo", en: MIR, Santiago LUZÓN, Diego (Editores), Responsabilidad penal de las empresas y sus órganos y responsabilidad por el producto, Barcelona: Bosch, 1996, pp. 99-127.

FRISCH, Wolfgang, "Zum gegenwärtigen Stand der Diskussion und zur Problematik der objektiven Zurechnungslehre”, GA (2003), pp. 719-743.

FRISCH, Wolfgang, "Wesenszüge rechtswissenschaftlichen Arbeitens - am Beispiel und aus der Sicht des Strafrechts (Kommentar)", en: ENGEL, Christoph; SCHÖN, Wolfgang (Editores), Das Proprium der Rechtswissenschaft, Tübingen: Mohr Siebeck, 2007.

FRISCH, Wolfgang, Estudios sobre imputación objetiva, Santiago de Chile: Legal Publishing Chile, 2012.

FRISCH, Wolfgang, La imputación objetiva del resultado - Desarrollo, fundamentos y cuestiones abiertas, Barcelona: Atelier, 2015. 
CONTRERAS, Lautaro. "Reglas extrajurídicas y creaciones de riesgos toleradas o desaprobadas en los delitos culposos de homicidio y lesiones".

FÜHR, Martin, “Technische Normen in demokratischer Gesellschaft”, ZUR (1993), pp. 99102.

GALÁN, Julio, Responsabilidad civil médica, $3^{\mathrm{a}}$ edición, Cizur Menor: Civitas, 2011.

GARRIDO, Mario, Derecho penal Parte general, Tomo II, $4^{\mathrm{a}}$ edición, Santiago: Editorial Jurídica de Chile.

GIL, Alicia, El delito imprudente - Fundamentos para la determinación de lo injusto imprudente en los delitos activos de resultado, Barcelona: Atelier, 2007.

GÓMEZ, Pilar, Tratamientos médicos: su responsabilidad penal y civil, $3^{\mathrm{a}}$ edición, Barcelona: Bosch, 2013.

GÖSSEL, Karl Heinz, “§ 42 Struktur und Formen der fahrlässigen Straftat”, en: GÖSSEL, Karl Heinz et al, Strafrecht Allgemeiner Teil Teilband 2 Erscheinungsformen des Verbrechens und Rechtsfolgen der Tat, $8^{\text {a }}$ edición, Heidelberg: Müller, 2014, pp. 179200

GROßE VORHOLT, André, Behördliche Stellungnahmen in der strafrechtlichen Produkthaftung -Zur Konkretisierung von Sorgfaltspflichten bei Risikoentscheidungen, Baden-Baden: Nomos, 1997.

GUÉREZ, Pablo, El tratamiento médico curativo y su licitud: el papel del consentimiento del paciente, Cizur Menor: Civitas, 2012.

HABERMAS, Jürgen, Faktizität und Geltung - Beiträge zur Diskurstheorie des Rechts und des demokratischen Rechtsstaats, 2a edición, Frankfurt am Main: Suhrkamp, 1992.

HECKMANN, Dirk, Geltungskraft und Geltungsverlust von Rechtsnormen - Elemente einer Theorie der autoritativen Normengeltungsbeendigung, Tübingen: Mohr Siebeck, 1997.

HERNÁNDEZ, Héctor, “Apuntes sobre la responsabilidad penal (imprudente) de los directivos de empresa", Revista de Estudios de la Justicia, № 10 (2008), pp. 175-198.

HERNÁNDEZ, Héctor, “Art. 2”, en: COUSO, Jaime; HERNÁNDEZ, Héctor (Editores), Código Penal comentado, Santiago de Chile: Legal Publishing, 2011, pp. 105-123.

HERSCHEL, Wilhelm, "Regeln der Technik”, NJW (1968), pp. 617-623.

HERSCHEL, Wilhelm, Rechtsfragen der Technischen Überwachung, $2^{\mathrm{a}}$ edición, Heidelberg: Recht und Wirtschaft, 1980.

HERZBERG, Rolf Dietrich, Die Verantwortung für Arbeitsschutz und Unfallverhütung im Betrieb, Köln: Carl Heymanns, 1984. 
Polít. crim. Vol. 13, № 25 (Julio 2018) Art. 11, pp. 387-444.

[http://www.politicacriminal.cl/Vol_13/n_25/Vol13N25A11.pdf]

HERZBERG, Rolf Dietrich, "Die Sorgfaltswidrigkeit im Aufbau der fahrlässigen und der vorsätzlichen Straftat”, JZ (1987), pp. 536-541.

HÖRL, Stephanie, Die unvertretbare Gefahr im deutschen Produkthaftungsrecht, Berlin: Duncker \& Humblot, 1999.

HOYER, Andreas, "Erlaubtes Risiko und technologische Entwicklung", ZStW 121 (2009), pp. 860-881.

HUFEN, Friedhelm, Staatsrecht II Grundrechte, 4ª edición, München: C. H. Beck, 2014.

IHLE, Judith, Ärztliche Leitlinien, Standards und Sozialrecht, Baden-Baden: Nomos, 2007.

IZQUIERDO, Manuel, La seguridad de los productos industriales - Régimen jurídicoadministrativo y protección de los consumidores, Madrid: Marcial Pons, 2000.

JAKOBS, Günther, Strafrecht, Allgemeiner Teil, $2^{\text {a }}$ edición, Berlin: Walter de Gruyter, 1991.

JARASS, Hans, "Der rechtliche Stellenwert technischer und wissenschaftlicher Standards Probleme und Lösungen am Beispiel der Umweltstandards", NJW (1997), pp. 12251231.

JESCHECK, Hans-Heinrich; WEIGEND, Thomas, Lehrbuch des Strafrechts Allgemeiner Teil, $5^{\text {a }}$ edición, Berlin: Duncker \& Humblot, 1996.

JORGE, Agustín, La imprudencia punible en la actividad médico-quirúrgica, Madrid: Tecnos, 1990.

KASPAR, Johannes, “Grundprobleme der Fahrlässigkeitsdelikte”, JuS (2012), pp. 16-21.

KATZENMEIER, Christian, Arzthaftung, Tübingen: Mohr Siebeck, 2002.

KINDHÄUSER, Urs, Gefährdung als Straftat - Rechtstheoretische Untersuchungen zur Dogmatik der abstrakten und konkreten Gefährdungsdelikte, Frankfurt am Main: Vittorio Klostermann, 1989.

KINDHÄUSER, Urs, Strafgesetzbuch Lehr- und Praxiskommentar, $7^{\mathrm{a}}$ edición, BadenBaden: Nomos, 2017.

KÖTZ, Hein, Deliktsrecht, 6ª edición, Neuwied: Luchterhand, 1994.

KREMER-BAX, Alexandra, Das personale Verhaltensunrecht der Fahrlässigkeitstat - Zur Individualisierung des Bewertungsgegenstands, Frankfurt am Main: Peter Lang, 1999.

KÜHL, Kristian, Strafrecht, Allgemeiner Teil, 8ª edición, München: Vahlen, 2017. 
CONTRERAS, Lautaro. "Reglas extrajurídicas y creaciones de riesgos toleradas o desaprobadas en los delitos culposos de homicidio y lesiones".

KUHLEN, Lothar, Fragen einer strafrechtlichen Produkthaftung, Heidelberg: Müller, 1989.

KUHLEN, Lothar, "Strafhaftung bei unterlassenem Rückruf gesundheitsgefährdender Produkte Zugleich Anmerkung zum Urteil des BGH vom 6. 7. 1990 - 2 StR 549/89 (NStZ 1990, 588)", NStZ (1990), pp. 566-570.

KUHLEN, Lothar, "Zur Problematik der nachträglichen ex ante-Beurteilung im Strafrecht und in der Moral", en: JUNG, Heike et al (Editores), Recht und Moral - Beiträge zu einer Standortbestimmung, Baden-Baden: Nomos, 1991, pp. 341-372.

LENCKNER, Theodor, "Technische Normen und Fahrlässigkeit", en: BOCKELMANN, Paul et al (Editores), Festschrift für Karl Engisch zum 70. Geburtstag, Frankfurt am Main: Klostermann, 1969, pp. 490-508.

MAIWALD, Manfred, “Zur Leistungsfähigkeit des Begriffs „erlaubtes Risiko“ für die Strafrechtssystematik”, en: VOGLER, Theo (Editor), Festschrift für Hans-Heinrich Jescheck zum 70. Geburtstag, Tomo I, Berlin: Duncker \& Humblot, 1985, pp. 405-425.

MAÑALICH, Juan, "La imprudencia como estructura de imputación”, Revista de Ciencias Penales, Sexta Época, Vol. XLII, N. 3 (2015), pp. 13-35.

MARBURGER, Peter, Die Regeln der Technik im Recht, Köln: Heymann, 1979.

MARBURGER, Peter, "Die haftungs- und versicherungsrechtliche Bedeutung technischer Regeln", VersR (1983), 597-608.

MARBURGER, Peter, "Herstellung nach zwingenden Rechtsvorschriften als Haftungsausschlußgrund im neuen Produkthaftungsrecht", en: Leßmann, Herbert et al (Editores), Festschrift für Rudolf Lukes zum 65 Geburtstag, Köln: Carl Heymanns, 1989, pp. 97-119.

MARBURGER, Peter, "Formen, Verfahren und Rechtsprobleme der Bezugnahme gesetzlicher Regelungen auf industrielle Normen und Standards", en: MÜLLERGRAFF, Peter-Christian (editor), Technische Regeln im Binnenmarkt, Baden-Baden: Nomos, 1991, pp. 27-56.

MAYER, Laura; VERA, Jaime, "Caso Pinzas: ¿responsabilidad penal por delito culposo en el ámbito médico? SCS, 23/04/2007, Rol N 6585-06”, en: VARGAS, Tatiana (Directora), Casos destacados Derecho penal - Parte General, Santiago: Legal Publishing Chile, 2015, pp. 149-170.

MAYER, Michael, Strafrechtliche Produktverantwortung bei Arzneimittelschäden - Ein Beitrag zur Abgrenzung der Verantwortungsbereiche im Arzneiwesen aus strafrechtlicher Sicht, Berlin: Springer, 2008. 
Polít. crim. Vol. 13, No 25 (Julio 2018) Art. 11, pp. 387-444.

[http://www.politicacriminal.cl/Vol_13/n_25/Vol13N25A11.pdf]

MERA, Jorge, "Los medios en el delito de lesiones graves (Art. 397 del C.P.)", Revista de Ciencias Penales, Tomo XXXIV (1975), pp. 163-200.

MIKUS, Rudolf, Die Verhaltensnorm des fahrlässigen Erfolgsdelikts, Berlin: Duncker \& Humblot, 2002.

MIR, Santiago, Derecho Penal Parte General, 3ª edición, Barcelona: PPU, 1990.

MIRANDA, Patricia, El sistema jurídico de la técnica: las normas técnicas, Memoria para optar al grado de Licenciado en Ciencias Jurídicas y Sociales, Universidad de Chile, Santiago de Chile, 2003.

MÜLLER-FOELL, Martina, Die Bedeutung technischer Normen für die Konkretisierung von Rechtsvorschriften, Heidelberg: Müller, 1987.

MÜNZBERG, Wolfgang, Verhalten und Erfolg als Grundlagen der Rechtswidrigkeit und Haftung, Frankfurt am Main: Klostermann, 1966.

MUÑOZ, Francisco; GARCÍA, Mercedes, Derecho penal Parte General, 9a edición, Valencia: Tirant lo Blanch, 2015.

MURMANN, Uwe, "Zur Berücksichtigung besonderer Kenntnisse, Fähigkeiten und Absichten bei der Verhaltensnormkonturierung", en: PUTZKE, Holm et al (Editores), Strafrecht zwischen System und Telos - Festschrift für Rolf Dietrich Herzberg zum siebzigsten Geburtstag am 14. Februar 2008, Tübingen: Mohr Siebeck, 2008, pp. 123 140.

MURMANN, Uwe, Grundkurs Strafrecht, $3^{\text {a }}$ edición, München: C. H. Beck, 2015.

NELL, Ernst Ludwig, Wahrscheinlichkeitsurteile in juristischen Entscheidungen, Berlin: Duncker \& Humblot, 1983.

NICKLISCH, Fritz, "Wechselwirkungen zwischen Technologie und Recht - Zur kontrollierten Rezeption wissenschaftlichtechnischer Standards durch die Rechtsordnung", NJW(1982), pp. 2633-2644.

NICKLISCH, Fritz, “Technische Regelwerke - Sachverständigengutachten im Rechtssinne?", NJW(1983), pp. 841-850.

NIETO, Adán, "§ 5 Autorregulación, “compliance” y justicia restaurativa”, en: ARROYO, Luis; NIETO, Adán (Directores), Autorregulación y sanciones, $2^{\mathrm{a}}$ edición, Cizur Menor: Thomson Reuters Aranzadi, 2015, pp. 99-134.

OSSANDÓN, María Magdalena, La formulación de tipos penales - Valoración crítica de los instrumentos de técnica legislativa, Santiago: Editorial Jurídica de Chile, 2009. 
CONTRERAS, Lautaro. "Reglas extrajurídicas y creaciones de riesgos toleradas o desaprobadas en los delitos culposos de homicidio y lesiones".

PAREDES, José Manuel, El riesgo permitido en Derecho penal (Régimen jurídico-penal de las actividades peligrosas), Madrid: Centro de publicaciones de la Secretaría General Técnica del Ministerio de Justicia e Interior, 1995.

PERRON, Walter, "StGB § 34 Rechtfertigender Notstand", en: Schönke/Schröder Strafgesetzbuch Kommentar, 29ª edición, München: C. H. Beck, 2014.

PIZARRO, Carlos, La responsabilidad civil médica, Santiago: Legal Publishing Chile, 2017.

POLITOFF, Sergio et al, Lecciones de Derecho penal chileno Parte General, $2^{\mathrm{a}}$ edición, Santiago de Chile: Editorial Jurídica de Chile, 2008.

PRITTWITZ, Cornelius, Strafrecht und Risiko - Untersuchungen zur Krise von Strafrecht und Kriminalpolitik in der Risikogesellschaft, Frankfurt am Main: Klostermann, 1993.

PUPPE, Ingeborg, “Anmerkungen zu BHGSt 37, 106”, JR (1992), pp. 30-34.

PUPPE, Ingeborg, “Vorbemerkungen zu $\S \S 13$ ff”, en: KINDHÄUSER, Urs; NEUMANN, Ulfrid; PAEFFGEN, Hans-Ullrich (Editores), Nomos Kommentar, Strafgesetzbuch, Tomo 1, 5 edición, Baden-Baden: Nomos, 2017.

RAWLS, John, Eine Theorie der Gerechtigkeit, Frankfurt am Main: Suhrkamp, 1975.

REUS, Katharina, Das Recht in der Risikogesellschaft - Der Beitrag des Strafrechts zum Schutz vor modernen Produktgefahren, Berlin: Duncker \& Humblot, 2010.

REYES, Ítalo, "Sobre la construcción de la exigencia de cuidado", Polit. Crim. Vol. 10 n 19 (2015), pp. 56-91, en: http://www.politicacriminal.cl/Vol_10/n_19/Vol10N19A3.pdf (visitado el 01.09.2017)

REYES, Ítalo, "Una aproximación a la imputación a título de imprudencia en el Código Penal chileno", Revista de Derecho de la Pontificia Universidad Católica de Valparaíso, XLVII, $2^{\circ}$ semestre (2016), pp. 245-278.

ROJAS, Christian, "Las implicancias jurídicas de la normalización técnica. Sus antecedentes, proyección y las manifestaciones para el caso de Chile", Revista de Derecho Universidad Católica del Norte, Año 16 - N 1 (2009), pp. 91-133.

ROMEO, Carlos, El médico ante el Derecho - La responsabilidad penal y civil del médico, Madrid: Servicio de Publicaciones Ministerio de Sanidad y Consumo, 1985.

ROSAS, Juan, "La delimitación del deber de cuidado en la imputación de responsabilidad penal por imprudencia médica", Doctrina y Jurisprudencia Penal, $\mathrm{N}^{\circ} 5$ (2011), pp. 334.

ROXIN, Claus, Strafrecht Allgemeiner Teil, Tomo 1, 4ª edición, München: C. H. Beck, 2006. 
Polít. crim. Vol. 13, No 25 (Julio 2018) Art. 11, pp. 387-444.

[http://www.politicacriminal.cl/Vol_13/n_25/Vol13N25A11.pdf]

RUDOLPHI, Hans-Joachim; JÄGER, Christian, "Vor $§ 1 ”$, en: WOLTER, Jürgen (Editor), Systematischer Kommentar zum Strafgesetzbuch, Tomo I, $8^{\text {a }}$ edición, actualizada a diciembre de 2014, Neuwied: Carl Heymanns, 2015.

SAMSON, Erich, "Probleme strafrechtlicher Produkthaftung”, StV (1991), pp. 182-186.

SATZGER, Die Europäisierung des Strafrechts - Eine Untersuchung zum Einflu $\beta$ des Europäischen Gemeinschaftsrechts auf das deutsche Strafrecht, Köln: Carl Heymanns, 2001.

SCHÄFER, Karl-Wilhelm, Das Recht der Regeln der Technik, Köln: sin editorial, 1965.

SCHAUMANN-WERDER, Hedda v., Strafrechtliche Produkthaftung im Europäischen Binnenmarkt - Der Einfluss europäischer Instrumente zur Herstellung und Aufrechterhaltung des Binnenmarktes, Köln: Carl Heymanns, 2008.

SCHENKE, Wolf-Rüdiger, "Die verfassungsrechtliche Problematik dynamischer Verweisungen", NJW (1980), pp. 743-749.

SCHMIDHÄUSER, Eberhard, Strafrecht Allgemeiner Teil Lehrbuch, $2^{\mathrm{a}}$ edición, Tübingen: Mohr Siebeck, 1975.

SCHMIDT-SALZER, Joachim, Produkthaftung - Bd. I Strafrecht, $2^{\mathrm{a}}$ edición, Heidelberg: Recht und Wirtschaft, 1988.

SCHMIDT-SALZER, Joachim, Produkthaftung - Bd. III/1 Deliktsrecht 1. Teil, $2^{\mathrm{a}}$ edición, Heidelberg: Recht und Wirtschaft, 1990.

SCHMUCKER, Andrea, Die "Dogmatik” einer strafrechtlichen Produktverantwortung, Frankfurt am Main: Peter Lang, 2001.

SCHROTH, Ulrich, "Die strafrechtliche Verantwortlichkeit des Arztes bei Behandlungsfehlern", en: ROXIN, Claus; SCHROTH, Ulrich (editores), Handbuch des Medizinstrafrechts, 2a edición, Stuttgart: Richard Boorberg, 2010, pp. 125-160.

SCHUMANN, Heribert, Strafrechtliches Handlungsunrecht und das Prinzip der Selbstverantwortung der Anderen, Tübingen: Mohr Siebeck, 1986.

SCHÜNEMANN, Bernd, "Moderne Tendenzen in der Dogmatik der Fahrlässigkeits- und Gefährdungsdelikte”, JA (1975), pp. 575-584.

SCHÜNEMANN, Bernd, "Las reglas de la técnica en Derecho penal", $A D P C P$ (1994), pp. 307-341.

SCHÜRER-MOHR, Wiebke, Erlaubte Risiken: Grundfragen des «erlaubten Risikos» im Bereich der Fahrlässigkeitsdogmatik, Frankfurt am Main: Peter Lang, 1998. 
CONTRERAS, Lautaro. "Reglas extrajurídicas y creaciones de riesgos toleradas o desaprobadas en los delitos culposos de homicidio y lesiones".

SERRANO, José, Teoría del delito imprudente (Doctrina general y Regulación legal), Madrid: Centro de Publicaciones de la Secretaría General Técnica del Ministerio de Justicia e Interior, 1991.

SIECKMANN, Jan-Reinard, “Abwägung von Rechten”, ARSP 81 (1995), pp. 164-184.

SILVA SÁNCHEZ, Jesús María, "La responsabilidad penal del médico por omisión”, La Ley 87-1, pp. 955-966.

SPINDLER, Gerald, Unternehmensorganisationspflichten - Zivilrechtliche und öffentlichrechtliche Regelungskonzepte, $2^{\mathrm{a}}$ edición, Göttingen: Universitätsverlag Göttingen, 2011.

STAUDT, Lea, Medizinische Richt- und Leitlinien im Strafrecht - Eine Untersuchung zur Möglichkeit der Bestimmung der unerlaubten Handlung beim Fahrlässigkeitsdelikt mit Hilfe medizinischer Richt- und Leitlinien, Frankfurt am Main: Peter Lang, 2012.

STERNBERG-LIEBEN, Detlev; SCHUSTER, Frank, "StGB § 15 Vorsätzliches und fahrlässiges Handeln", en: Schönke/Schröder, Strafgesetzbuch, Kommentar, 29a edición, München: C. H. Beck, 2014.

STRATENWERTH, Günter, Derecho penal parte General I - El hecho punible, $4^{\mathrm{a}}$ edición, Buenos Aires: Hammurabi, 2005.

TAUPITZ, Jochen, "Verbindlichkeit unterschiedlicher Leitlinien", en: Arbeitsgemeinschaft Rechtsanwälte im Medizinrecht e.V. (Editores), Dokumentation und Leitlinienkonkurrenz - die Verschriftlichung der Medizin, Berlin: Springer, 2007, pp. 101-121.

TORÍO, Ángel, "El deber objetivo de cuidado en los delitos culposos”, ADPCP (1974), Vol. XXVII, pp. 25-59.

TRATZ, Stefan Peter, Die zivilprozessuale Bedeutung der Regeln der Technik, Würzburg: sin editorial, 2001.

ULSENHEIMER, Klaus, Arztstrafrecht in der Praxis, 5ª edición, Heidelberg: Müller, 2015.

VAN WEEZEL, Alex, "Parámetros para el enjuiciamiento de la infracción al deber de cuidado en los delitos imprudentes", Revista Chilena de Derecho, Vol. 26 N² (1999), pp. 323-336.

VARGAS, Tatiana, "La imprudencia médica. Algunos problemas de imputación de lo injusto penal", Revista de Derecho Universidad Católica del Norte, Año 17 - N² (2010), pp. 99-132. 
Polít. crim. Vol. 13, № 25 (Julio 2018) Art. 11, pp. 387-444.

[http://www.politicacriminal.c1/Vol_13/n_25/Vol13N25A11.pdf]

VEIT, Barbara, Die Rezeption technischer Regeln im Strafrecht und Ordnungswidrigkeitenrecht unter besonderer Berücksichtigung ihrer verfassungsrechtlichen Problematik, Düsseldorf: Werner, 1989.

VOGEL, Joachim, "§ 15 Vorsätzliches und fahrlässiges Handeln”, en: LAUFHÜTTE, Heinrich Wilhelm et al (Editores), Strafgesetzbuch Leipziger Kommentar Großkommentar, 12a edición, Berlin: Walter de Gruyter, 2007.

WAGNER, Gerhard, "BGB $\S 823$ Schadenersatzpflicht”, en: SÄCKER, Franz Jürgen et al (Editores), Münchener Kommentar zum Bürgerlichen Gesetzbuch, Tomo 5, 6 a edición, München: C. H. Beck, 2013.

WAGNER, Gerhard, "BGB $\S 823$ Schadenersatzpflicht”, en: SÄCKER, Franz Jürgen et al (Editores), Münchener Kommentar zum Bürgerlichen Gesetzbuch, Tomo 6, $7^{\mathrm{a}}$ edición, München: C. H. Beck, 2017.

WALTER, Alexander, "Medizinische Leitlinien und Behandlungsfehlerhaftung", GesR (2003), pp. 165-171.

WEI $\beta$, Holger, Die rechtliche Gewährleistung der Produktsicherheit, Baden-Baden: Nomos, 2008.

WELZEL, Hans, Derecho penal alemán, $11^{\mathrm{a}}$ edición alemana (4 ${ }^{\mathrm{a}}$ edición castellana), Santiago: Editorial Jurídica de Chile, 1993.

WESSELS, Johannes et al, Strafrecht Allgemeiner Teil Die Straftat und ihr Aufbau, 46 edición, Heidelberg: Müller, 2016.

WOLFF, Hagen, “§ 319 StGB Baugefährdung”, en: LAUFHÜTTE, Heinrich Wilhelm et al (Editores), Leipziger Kommentar Strafgesetzbuch, 11a Tomo, 12a edición, Berlin: De Gruyter, 2008.

ZIELINSKI, Diethart, Handlungs- und Erfolgsunwert im Unrechtsbegriff - Untersuchungen zur Struktur von Unrechtsbegründung und Unrechtsausschluß, Berlin: Duncker \& Humblot, 1973. 